Universidade de São Paulo

Faculdade de Filosofia, Letras e Ciências Humanas

Departamento de Geografia

Marcos Alexandre Milanesi

\title{
Avaliação do Efeito Orográfico na Pluviometria de Vertentes Opostas da IIha de São Sebastião (Ilhabela-SP)
}

São Paulo

2007 
Marcos Alexandre Milanesi

\title{
Avaliação do Efeito Orográfico na Pluviometria de Vertentes Opostas da Ilha de São Sebastião (Ilhabela - SP)
}

\begin{abstract}
Dissertação apresentada ao Programa de Pós-Graduação em Geografia Física, da Faculdade de Filosofia, Letras e Ciências Humanas da Universidade de São Paulo, para obtenção do título de Mestre em Geografia.
\end{abstract}

Orientador: Prof. Dr. Emerson Galvani 


\title{
Folha de aprovação
}

\author{
Autor: Marcos Alexandre Milanesi \\ Título do trabalho: "Avaliação do Efeito \\ Orográfico na Pluviometria de Vertentes \\ Opostas da Ilha de São Sebastião \\ (Ilhabela - SP)" \\ Natureza do trabalho: Dissertação \\ Grau pretendido: Mestre \\ Instituição: Universidade de São Paulo \\ Área de concentração: Geografia Física \\ Orientador: Emerson Galvani \\ São Paulo \\ Ano de depósito: 2007 \\ Volumes: 01
}

Data de aprovação:

Orientador: Prof. Dr. Emerson Galvani (USP-FFLCH-DG)

Prof. Dr. João Lima Sant'Anna Neto (FCT/UNESP-Pres. Prudente)

Prof. Dr. José Bueno Conti (USP-FFLCH-DG) 


\section{Dedicatória}

À minha mulher Adriana,

Que envolve em seu corpo

O maior presente do Universo:

Nosso filho em seu ventre. 


\section{AGRADECIMENTOS}

Gostaria de expressar a minha enorme gratidão a todas as pessoas e instituições envolvidas na conclusão deste estudo, pois que, sem os quais, este não se realizaria.

Ao meu orientador e amigo, Emerson Galvani, pela atenção, apoio e estímulo em todas as fases deste trabalho.

Aos professores doutores Ailton Luchiari, Luci Hidalgo Nunes, Luis Antônio Bittar Venturi, Maria Elisa Siqueira Silva, Mário de Biase e Mônica Arroyo, pelas considerações, revisões e sugestões, que em muito contribuíram com suas visões científicas.

O meu especial agradecimento e homenagem ao Prof. Dr. José Bueno Conti, pela orientação desde o meu primeiro projeto de pesquisa na graduação.

Ao colega Ricardo Augusto Felício pela disponibilidade com as fotos, com o modelo e com as nuvens.

Ao amigo Rogério Rozolén Alves, técnico do Laboratório de Climatologia e Biogeografia (LCB) da Faculdade de Filosofia, Letras e Ciências Humanas (FFLCH) da Universidade de São Paulo (USP).

À USP e à FFLCH, na forma do Programa de Pós-Graduação em Geografia Física pelo auspício desta pesquisa.

À CAPES, pelo auxílio financeiro por meio da bolsa Pro Reitoria.

Ao Instituto Florestal (SP) e ao Parque Estadual de Ilhabela, à diretora Marília Britto de Moraes, por acolher a pesquisa e disponibilizar a infra-estrutura da unidade.

Ao auxiliar de pesquisa do parque, Marcos Aurélio, pela inestimável ajuda e outros funcionários como João, Silas, Flávio, pois não me lembro do nome de todos.

Às comunidades caiçaras que prestaram seu apoio e simpatia Canto do Gato e Praia do Meio.

A algumas das pessoas mais simpáticas e generosas que já conheci Ângela, Áureo e mulher.

Àqueles que de alguma maneira se responsabilizaram pela segurança dos pluviômetros, Espaço Ilhabela, Seu Quinzinho, Fernandinho, Da. Isadaia e Luis.

Aos meus primos Carlos e Marcelo, pelo suporte técnico-operacional. 
Aos meus queridos contemporâneos, por se fazerem presentes em mais essa caminhada Ciça, Douglas, Daniela e Nádia.

$E$, finalmente, a Adriana, minha mulher pelo ombro amigo e pela prática da atitude positiva da compreensão em todos os momentos. 


\title{
TEMPESTADE
}

\author{
(Maskavo Roots)
}

Chegou a tempestade devastando o lugar

E quem viu desesperou-se e começou a chorar

$\mathrm{O}$ frio, queimando as plantas, castigando animais

A fome era o que mais assolava

Matando bons e maus em uma só tacada

O sol retoma logo a dianteira

Mandando avisar que o céu é dele e que tudo vai mudar

Tudo vai mudar

E já não existia mais tristeza no ar

Assim que o sol nasceu e começou a brilhar

A luz tranqüilizou toda a população

A chuva já não nos preocupava

Havia novo gás pra crowd da parada

É o sol quem toma conta do planeta

E manda avisar que o seu povo não precisa mais chorar

Não precisa mais chorar. 


\section{RESUMO}

"Avaliação do Efeito Orográfico na Pluviometria de Vertentes Opostas da Ilha de São Sebastião (Ilhabela - SP)"

Com o intuito de se avaliar as diferenças pluviométricas nas vertentes continental e oceânica da Ilha de São Sebastião (Ilhabela - SP) para validação da ocorrência do efeito orográfico, foram instalados ao longo da Estrada de Castelhanos um conjunto de treze pluviômetros experimentais. Os totais mensais, obtidos no ano hidrológico 2004/2005, foram correlacionados, de forma geral, a outros postos pluviométricos da região, às altitudes diversas e à atuação das correntes de sudeste (predominantes). Os resultados apontam para o relevo como responsável por interferir no ritmo pluvial da região, claramente diferenciado na ilha e na distribuição espacial da chuva local. A vertente continental apresenta, em média, 20\% menos chuva que a vertente oceânica a barlavento, o que caracteriza a sombra de chuva. Na vertente oceânica, verificou-se intensificação e aumento das quantidades de chuva a partir dos $300 \mathrm{~m}$ de altitude. O total mensal máximo foi observado a $600 \mathrm{~m}$ de altitude $(708,5 \mathrm{~mm}$, em março/2005). Também foi calculado o gradiente pluviométrico em função do relevo que apresenta, em média, o acréscimo de $2,5 \mathrm{~mm}$ de chuva a cada metro de altitude.

\section{PALAVRAS-CHAVE}

Ilha de São Sebastião, precipitação, efeito orográfico, chuva orográfica, sombra de chuva. 


\begin{abstract}
"Evaluation of orographic effect in the rainfall/precipitation of opposite slopes of São Sebastião Island (Ilhabela - SP)"

In order to provide data for the evaluation of rainfall differences on the continental and sea slopes of São Sebastião Island (Ilhabela - SP) and to validate the occurrence of orographic effect, a set of 13 experimental rain gauges were installed throughout the Estrada de Castelhanos. The monthly totals from the 2004/2005 hydrological year were compared to other rainfall data recording posts, to different altitudes and to (predominant) southeastern currents. The results show topography as an agent interfering with the regional precipitation rhythm, clearly distinct in the island and in the spatial distribution of the local rain. The continental slope presents, in average, $20 \%$ less rain than the windward sea slope, which characterizes the rain shadow. In the sea slope, intensification and increase of the rainfall begins at $300 \mathrm{~m}$. The maximum monthly totals were observed at $600 \mathrm{~m}$ altitude $(708.5 \mathrm{~mm}$, in march/2005).
\end{abstract}

\title{
KEY WORDS
}

São Sebastião Island, slope, precipitation, orographic effect, orographic rainfall, rain shadow. 


\section{LISTA DE FIGURAS}

Figura 1 - Localização da área de estudo no contexto nacional e estadual............................. 21 Figura 2 - Vista do ancoradouro do TEBAR da PETROBRÁS, no Canal de São Sebastião, com o setor norte de Ilhabela em segundo plano.

Figura 3 - Fotomontagem da vista da vertente continental da ilha, setor norte - centro, a partir da

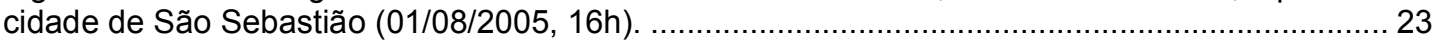

Figura 4 - Imagem da área de estudo, satélite Landsat 5TM, de 20 de agosto de $1988 \ldots \ldots \ldots \ldots . . . .24$

Figura 5 - Imagem da Praia de Castelhanos e a estreita área da planície litorânea que ocupa

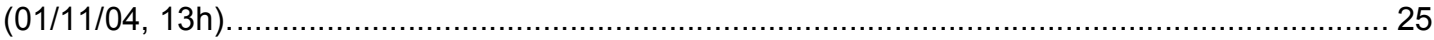

Figura 6 - Parte da carta topográfica São Sebastião e a localização dos pluviômetros ao longo da

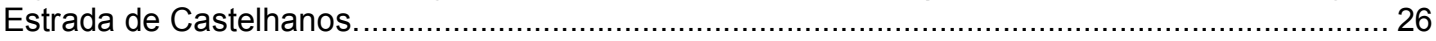

Figura 7 - Imagem da Estrada de Castelhanos, na Serrinha (divisor de águas) sendo trilhada por

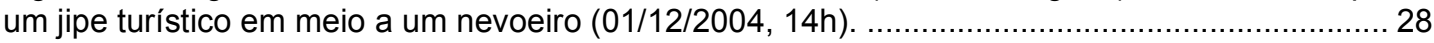

Figura 8 - Imagem da vertente oceânica da llha de São Sebastião e localização aproximada da

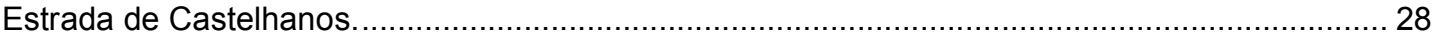

Figura 9 - Perfil topográfico da Estrada de Castelhanos e localização dos pluviômetros............... 29

Figura 10 - Imagem da Estrada de Castelhanos sendo desobstruída de um deslizamento, após

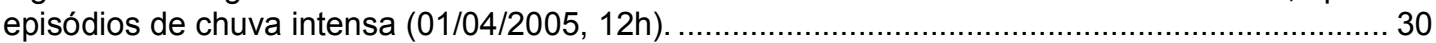

Figura 11 - Imagem da Serrinha (divisor de águas) e do posto 6 (690m), na Estrada de

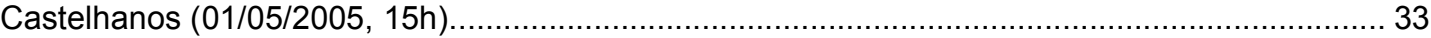

Figura 12 - Parte da Carta de isoietas da região mais chuvosa do Brasil.................................. 35

Figura 13 - Imagem da área de estudo, satélite CBERS2 CCD, de 20 de março de 2006, com

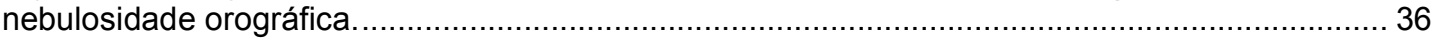

Figura 14 - Normais de insolação e nebulosidade para o posto Ubatuba, entre 1961 e 1990 ....... 38

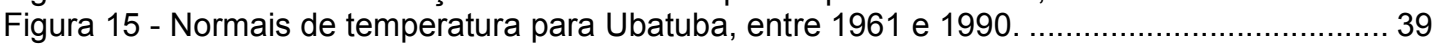

Figura 16 - Normais de precipitação e chuva máxima em 24h para o posto Ubatuba, entre 1961 e

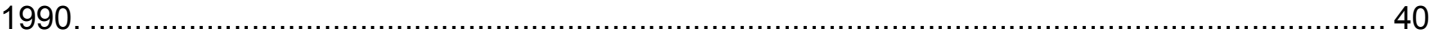

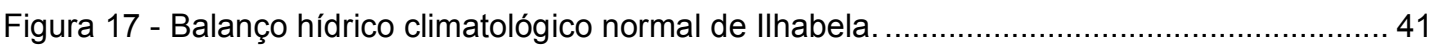

Figura 18 - Média climatológica do acumulado anual da precipitação para os postos do DAEE

Ubatuba, Caraguatatuba, Porto Novo, São Francisco, Ilhabela, Burrifas e Maresias. ................. 44

Figura 19 - Imagem da vertente continental da Ilha de São Sebastião, vista a partir da balsa.

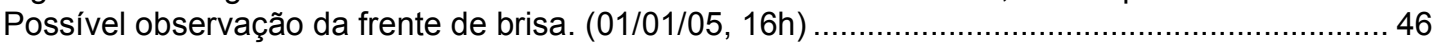

Figura 20 - Média climatológica dos totais anuais de chuva nos postos pluviométricos do DAEE na

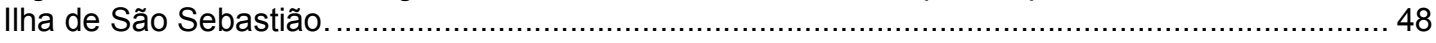

Figura 21 - Média climatológica mensal da precipitação para os postos do DAEE Ilhabela, Usina

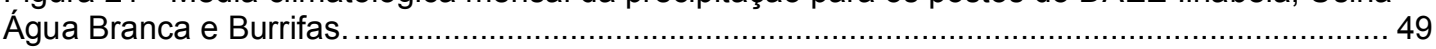

Figura 22 - Fotomontagem da vertente continental da Ilha de São Sebastião, vista a partir da balsa,

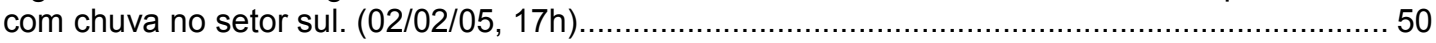

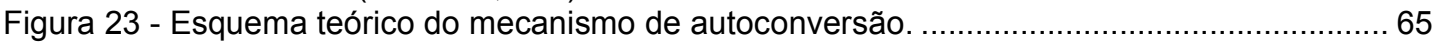

Figura 24 - Esquema teórico do mecanismo de convecção disparada....................................6 65

Figura 25 - Esquema teórico do mecanismo seeder-feeder, proposto por Bergeron (1968).........66

Figura 26 - Pluviômetros experimentais instalados em Ilhabela (à esquerda, o menor). ...............85

Figura 27 - Recipientes de medida (becker) utilizados para quantificação dos volumes de chuva.86

Figura 28 - Trabalho de desmontagem do pluviômetro experimental para medição da chuva. ..... 93

Figura 29 - Radiação solar acumulada média para a PCD Caraguatatuba durante o ano hidrológico

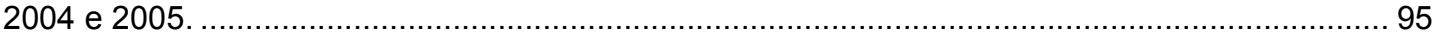

Figura 30 - Temperaturas média, média das máximas e média das mínimas para a PCD de

Caraguatatuba durante o ano hidrológico 2004 e 2005.................................................. 97

Figura 31 - Pressão média, para a PCD Caraguatatuba durante o ano hidrológico 2004 e 2005.. 98

Figura 32 - Direção média do vento, direção média das velocidades máximas e moda da direção

do vento para a PCD Caraguatatuba durante o ano hidrológico 2004 e 2005 .............................99

Figura 33 - Umidade relativa do ar média para a PCD Caraguatatuba durante o ano hidrológico

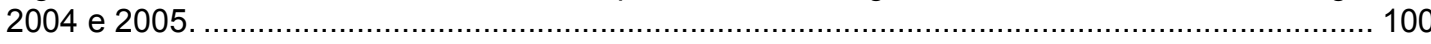

Figura 34 - Chuva totalizadora mensal e máximos em 24h para a PCD Caraguatatuba durante o

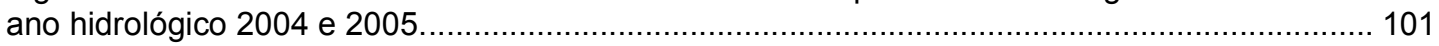

Figura 35 - Distribuição da chuva sazonal para a PCD Caraguatatuba durante o ano hidrológico

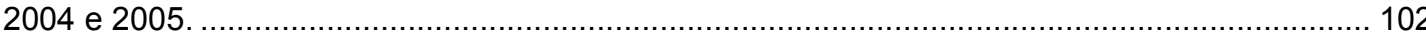


Figura 36- Distribuição mensal dos totais de chuva para o ano hidrológico de 2004/2005 na Estrada de Castelhanos, Ilhabela (SP).

Figura 37 - Distribuição sazonal dos totais de chuva para o ano hidrológico de 2004/2005 em Ilhabela. 108

Figura 38 - Precipitação mensal para os postos do INMET e DAEE, PCD de Caraguatatuba e dos dados observados nos pluviômetros instalados na llha de São Sebastião para o ano hidrológico de 2004/2005. 109

Figura 39 - Precipitação mensal para os postos Caraguatatuba (PCD), p1, p2, p3 (vertente continental), p4, p5 e p6 (vertente oceânica), além da média do Trabalho de Campo para o ano hidrológico de 2004/2005.

Figura 40 - Desvios relativos dos valores de chuva entre os postos de llhabela e o PCD

Caraguatatuba para o ano hidrológico de 2004/2005. 113

Figura 41 - Variação da chuva trimestral acumulada em todos os postos de cada vertente na Estrada de Castelhanos, para o ano hidrológico de 2004/2005.

Figura 42 - Variação espacial da chuva para o ano hidrológico de 2004/2005, em Ilhabela....... 116

Figura 43 - Comparação entre os postos de planície quanto à variação espacial da chuva para o ano hidrológico de 2004/2005, em Ilhabela.

Figura 44 - Comparação entre os postos de vertente quanto à variação espacial da chuva para o ano hidrológico de 2004/2005, em Ilhabela.

Figura 45 - Comparação entre os postos do divisor de águas quanto à variação espacial da chuva

para o ano hidrológico de 2004/2005, em Ilhabela.

Figura 46 - Correlação entre o aumento da chuva com a altitude para a vertente continental da

Estrada de Castelhanos no ano hidrológico de 2004/2005.

Figura 47 - Correlação entre o aumento da chuva com a altitude para a vertente oceânica da Estrada de Castelhanos no ano hidrológico de 2004/2005.

Figura 48 - Síntese espaço-temporal da distribuição da chuva na Estrada de Castelhanos para o ano hidrológico de 2004/2005.

Figura 49 - Esquema teórico da interação da entre a brisa do mar e os ventos predominantes e distribuição espacial aproximada da nebulosidade na Estrada de Castelhanos, baseado em Leopold (1949).

Figura 50 - Imagens do setor norte da Ilha de São Sebastião, a partir da Ponta Azeda (Ubatuba), registrando a formação de nebulosidade de desenvolvimento vertical (jan/2005, às 13h - a, e às $13 \mathrm{~h} 15 \mathrm{~min}$ - b). Em a - cumulus humilis e, em b - cumulus mediocris.

Figura 51 - Esquema teórico da distribuição da chuva na Estrada de Castelhanos. 


\section{LISTA DE QUADROS}

Quadro 1 - Posto meteorológico do INMET utilizado para a caracterização climática regional da área de estudo. 80 Quadro 2 - Postos pluviométricos do DAEE utilizados para a base de dados regional.................. 81 Quadro 3 - Postos pluviométricos do DAEE utilizados para a base de dados regional e local ...... 82 Quadro 4 - Plataforma de coleta de dados (PCD) meteorológicos do CPTEC/INPE referencial da

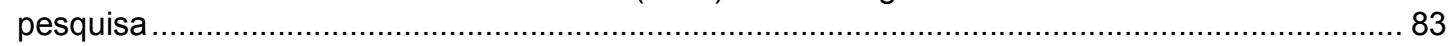
Quadro 5 - Postos pluviométricos originais instalados na llha de São Sebastião ………............... 88

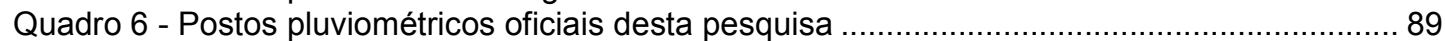
Quadro 7 - Climatologia de sistemas frontais, média histórica e ano hidrológico 2004-2005....... 105 


\section{LISTA DE TABELAS}

Tabela 1 - Banco de dados pluviométricos referente ao ano hidrológico de 2004 a 2005 na Estrada de Castelhanos - Ilhabela (SP). 106 Tabela 2: Desvios relativos ao total mensal da precipitação dos postos pluviométricos em relação ao posto Caraguatatuba (INPE) durante o ano hidrológico de 2004/2005 


\section{SUMÁRIO}

FOLHA DE APROVAÇÃO

DEDICATÓRIA

AGRADECIMENTOS

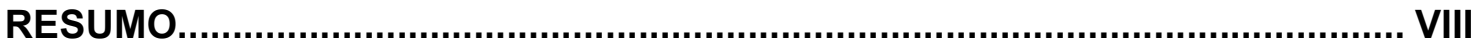

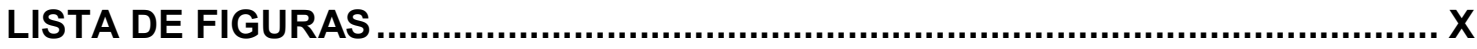

LISTA DE QUADROS .....................................................................................

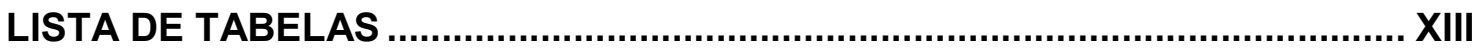

SUMÁRIO

1) Introdução

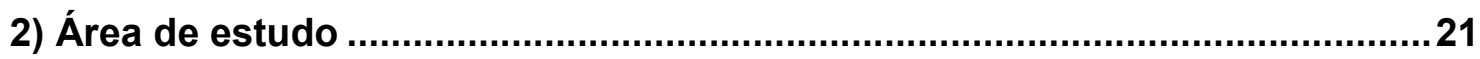

2.1. Caracterização natural ..............................................................................31

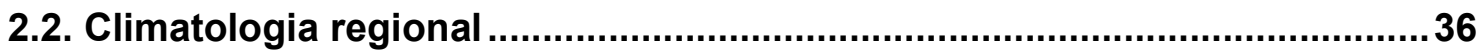

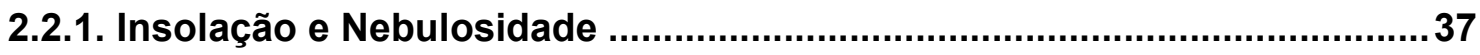

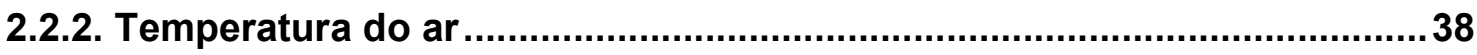

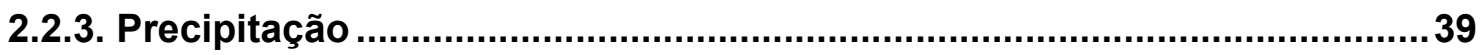

2.2.4. Balanço Hídrico Climatológico ................................................................40

2.2.5. Dinâmica Regional da Pluviosidade ..........................................................41

2.3. Pluviometria regional .....................................................................................

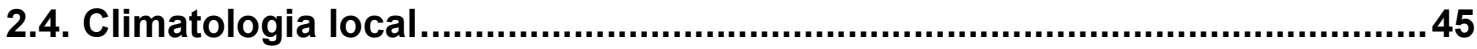

2.5. Pluviometria local ...........................................................................................

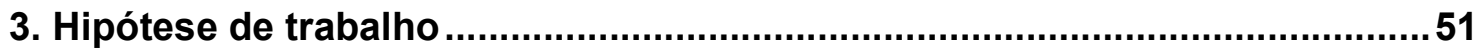

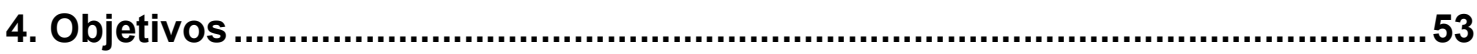


5. Referencial Teórico e Metodológico …….........................................................

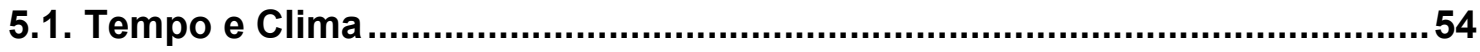

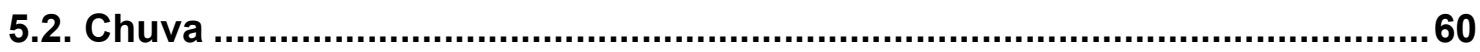

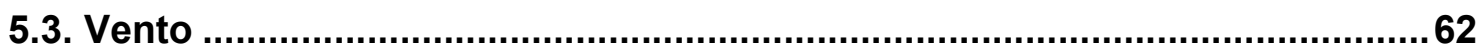

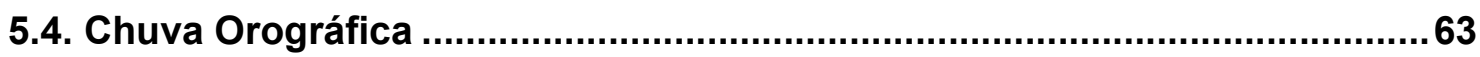

5.4.1. Mecanismos da Precipitação Orográfica ...................................................67

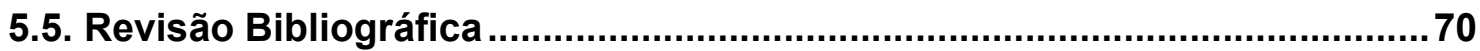

6. Referência Procedimental ..........................................................................

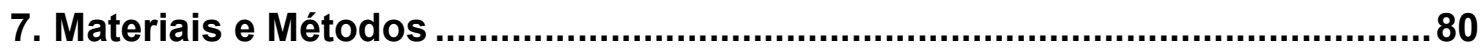

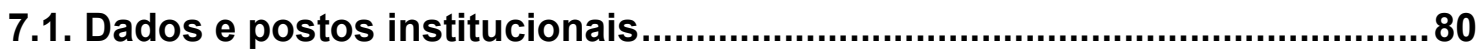

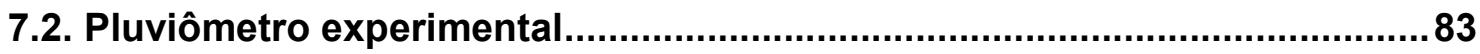

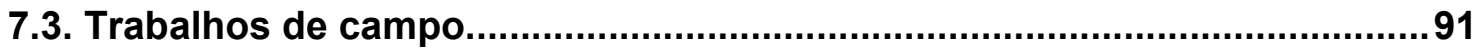

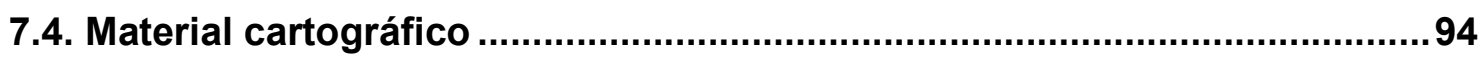

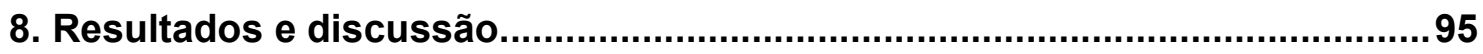

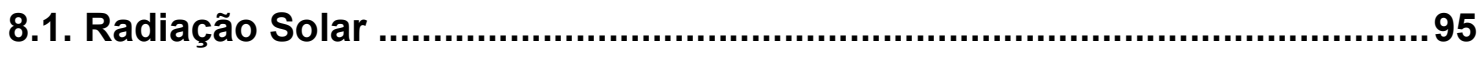

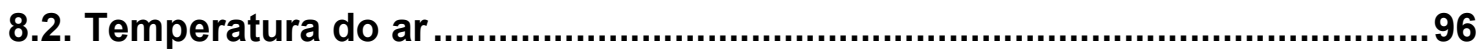

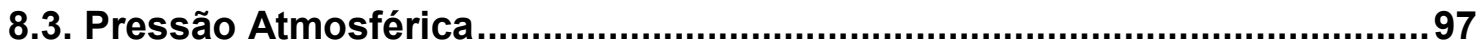

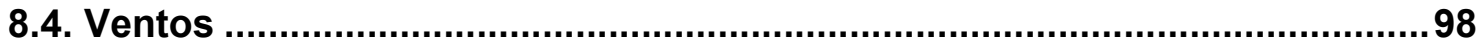

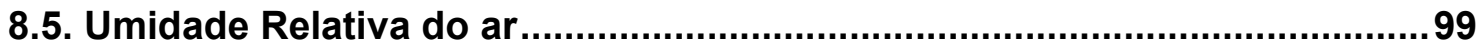

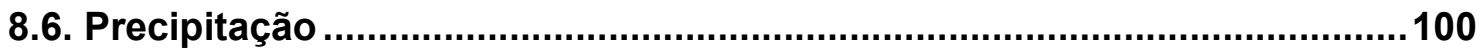

8.6.1. Gênese da Precipitação ...........................................................................103

8.7. A pluviometria da Estrada de Castelhanos ................................................106

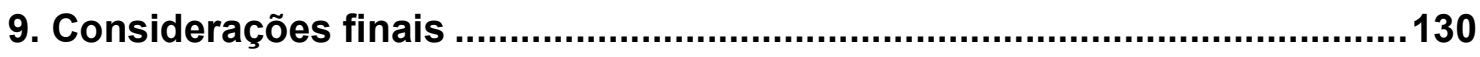

10. Referências bibliográficas....................................... Erro! Indicador não definido. 


\section{1) Introdução}

O efeito orográfico refere-se aos resultados decorrentes da interação entre a atmosfera e a superfície terrestre. De maneira geral e sem minimizar a importância dos oceanos, as formas de relevo como montanhas, cordilheiras e escarpas relacionam-se com as massas de ar controlando os atributos do clima como a temperatura, a pressão, ventos, chuva, entre outros.

A quantidade de energia solar recebida por cada ponto do planeta ao longo do dia varia conforme a latitude, a altitude, a altura do sol e especialmente, às características da superfície a ela exposta. Por isso, as dimensões do relevo: a forma, o comprimento, a largura, a altura e o ângulo de inclinação e a orientação de suas vertentes, mais o tipo de cobertura e uso do solo (albedo) influenciam de maneira direta nas características do ambiente atmosférico local ao refletir diferencialmente a energia de volta à própria atmosfera.

Os resultados desses controles são identificados no meio acadêmico como o aquecimento diferencial das superfícies, o surgimento de células locais de alta e baixa pressão, formação de brisas, obstrução de ventos, formação de determinados tipos de nuvens, distribuição diferenciada de chuvas. E conhecidos são as resultantes desses processos as brisas marítimas, os ventos anabático e catabático, a chuva orográfica e a sombra de chuva.

É a relação intrínseca de uma série de processos físicos e químicos que se materializam sob a forma de fenômenos e efeitos atmosféricos que identificam climaticamente cada lugar, cada paisagem. Exemplos não faltam. Os picos nevados do Himalaia (Nepal), as altas temperaturas da depressão de Qattara (Egito), o 
deserto do Atacama (Chile) e a grande quantidade de chuvas do Havaí (EUA), são alguns. No Brasil, o Monte Roraima (RR), na divisa com a Venezuela e o Planalto da Borborema, que se estende desde o Alagoas até o Rio Grande do Norte, respondem por índices pluviométricos diferenciados nas regiões em que se localizam.

Mas, é no Sudeste, na zona costeira de São Paulo que encontramos uma das localidades mais chuvosas do Brasil. Muito influenciada pela orografia, a localidade paulista mais chuvosa está na Serra do Mar, nas proximidades da Cachoeira do Rio Itapanhaú, na Represa de Ponte Nova, a 450m de altitude, onde a média anual pode exceder os 4000mm (NUNES, 1993) no município de Salesópolis. O relevo é o controle que mais se destaca por gerar as diferenças de temperatura e na distribuição e quantidade de chuvas na região.

A chuva orográfica é um tipo de precipitação local que se forma quando uma barreira de relevo impede a passagem dos ventos marítimos, quase saturados de vapor d'água pela evaporação do mar. Durante a transposição desse obstáculo, os ventos, em ascensão, se resfriam e condensam o vapor de água originando nuvens e chuva a barlavento, isto é, na vertente exposta ao fluxo de ar. O efeito associado a esse fenômeno é a sombra de chuva e ocorre na vertente oposta, em abrigo, a sotavento dos fluxos. Após a transposição do obstáculo, o fluxo de ar, agora descendente, se aquece e "resseca", diminuindo consideravelmente a quantidade de umidade presente nesta parcela da atmosfera.

Autores como Bergeron (1968), o pai da Teoria da Chuva Orográfica, Smith (1979) em The influence of mountains on the atmosphere (A influência das montanhas na atmosfera), Barry e Chorley (1979) em Atmosphere, Weather and Climate (Atmosfera, tempo e clima) desenvolveram os clássicos sobre a temática. 
Entre os brasileiros de maior destaque são Conti (1967 e 1975), Nunes (1993) e Blanco (2000).

Puwaneswaran e Smithson (1991), demonstraram que no Sri Lanka a quantidade máxima de chuva é observada entre os 500 e $800 \mathrm{~m}$ e que em áreas tropicais úmidas a quantidade de chuva precipitada em um dado lugar aumenta até determinada altitude, quando passa a decrescer e que, em função da condensação do ar marítimo, que pode ocorrer em altitude, sobre relevos diferenciados e até uma certa distância da costa.

Inserida em um quadro morfo-climático regional semelhante ao da Represa de Ponte Nova encontra-se a NE, a llha de São Sebastião, a maior ilha marítima brasileira. Situada na fachada oriental da América do Sul, na Serra do Mar e na latitude do Trópico de Capricórnio. Apresenta, condições favoráveis à formação de chuva orográfica, relevo pronunciado, cobertura de vegetação de Mata Atlântica, ventos predominantemente oceânicos. A ilha, em termos locais, é a própria barreira aos fluxos de ar predominantes e, por meio de sua morfologia (altitude, comprimento e orientação), certamente exerce controle sobre a precipitação regional e local.

Esta dissertação de mestrado busca avaliar a existência dos efeitos do relevo na llha de São Sebastião, no Litoral Norte paulista, em particular, sobre a formação e distribuição da chuva orográfica nas duas grandes vertentes da ilha, aquela voltada para o oceano (barlavento) e a outra, voltada para o continente (sotavento). Podemos dizer que este é um trabalho sobre a variabilidade climática da constituinte chuva ou como as condicionantes geográficas locais e suas interações com a atmosfera geográfica influenciam nas variações internas da chuva.

Consideramos, então, como área de estudo a porção central da llha de São Sebastião (sede do município de llhabela) no setor litorâneo lesnordeste do Estado 
de São Paulo (tratado aqui como Litoral Norte) e como objeto de estudo, a chuva e suas relações com o relevo no intuito de desvendar parte da realidade climática desta área. Interessa-nos realizar uma análise da dinâmica da chuva associada à influência do relevo: formação, intensificação e distribuição da pluviosidade.

Diversos são os motivos que justificam a necessidade deste estudo.

O município de Ilhabela conta com apenas dois pluviômetros na vertente continental da Ilha de São Sebastião, o que impossibilita qualquer análise climática mais aprofundada na área.

A compreensão do ritmo e do regime climático, e em particular da chuva, em fachadas litorâneas orientais, sujeitas a grande variabilidade espaço-temporal e quantitativa de eventos chuvosos, constitui subsídio fundamental e estratégico para a confecção de um bom instrumento de planejamento urbano, dando maior visibilidade às áreas de risco.

Dependem também as ações mais significativas da Defesa Civil, de planejamentos antecipados, que essencialmente envolve o conhecimento do retorno dos eventos de intensidade extrema de chuva, ou seca, ou quando como é mais acionada, no caso de enchentes e deslizamentos de encostas.

A expansão do turismo certamente se beneficia dos aspectos naturais $O$ desenvolvimento do setor econômico terciário alavancado pela expansão das atividades turísticas que se beneficiam do ambiente local depende diretamente de sua relação com as nuances climáticas de seu território onde são praticadas.

A Ilha de São Sebastião ainda pode ser considerada como uma área preservada, pois conta com a existência do Parque Estadual de Ilhabela (PElb) que cobre aproximadamente $85 \%$ da extensão do município. O parque oferece infraestrutura básica para a realização da pesquisa. Porém, há um número relativamente 
pequeno de pesquisas desenvolvidas ou em desenvolvimento e, também há carência de estudos climatológicos - o parque não possui uma estação climatológica oficial e, não há conhecimentos sistematizados da chuva em sua área, que a caracterizem concernentemente ou que sirvam de banco de dados transversal a outros ramos de conhecimentos afins, geomorfologia, hidrologia, biogeografia, ecologia, botânica, entre outros.

A região em si ainda engloba um importante entroncamento rodo-portuário constituído pela BR-101 (Rio-Santos), SP-110 (Rodovia dos Tamoios) principal elo entre o Vale do Paraíba e o Litoral Norte, o porto de São Sebastião, o Terminal Almirante Barroso (TEBAR, da PETROBRÁS) e a balsa de llhabela que, apesar de se apresentarem numa rede de baixa densidade, possuem fluxo intenso de veículos leves e pesados, que se avoluma em períodos de férias e feriados prolongados, necessitando por conta disso, monitoramento climático e pluviométrico constante, principalmente no verão tanto para planos de manutenção das vias como para o monitoramento das encostas. 


\section{2) Área de estudo}

A área de estudo (Figura 1) localiza-se no Litoral Norte do Estado de São Paulo, distante $210 \mathrm{~km}$ a lesnordeste da capital. O arquipélago de São Sebastião é composto por lajes, ilhotas e mais nove ilhas, sendo a llha de São Sebastião, a maior, com $346 \mathrm{~km}^{2}$. Esta, por sua vez, abriga a sede do município de Ilhabela, sob as coordenadas geográficas latitude $23^{\circ} 46^{\prime} 28^{\prime \prime}$ Sul e longitude $45^{\circ} 21^{\prime} 20^{\prime \prime}$ Oeste (10m de altitude). É limitada pelo canal de mesmo nome com comprimento de 22,7 km e 8 km de largura, aproximadamente, com os municípios de São Sebastião a oeste, Caraguatatuba a noroeste e com o Oceano Atlântico, a leste.

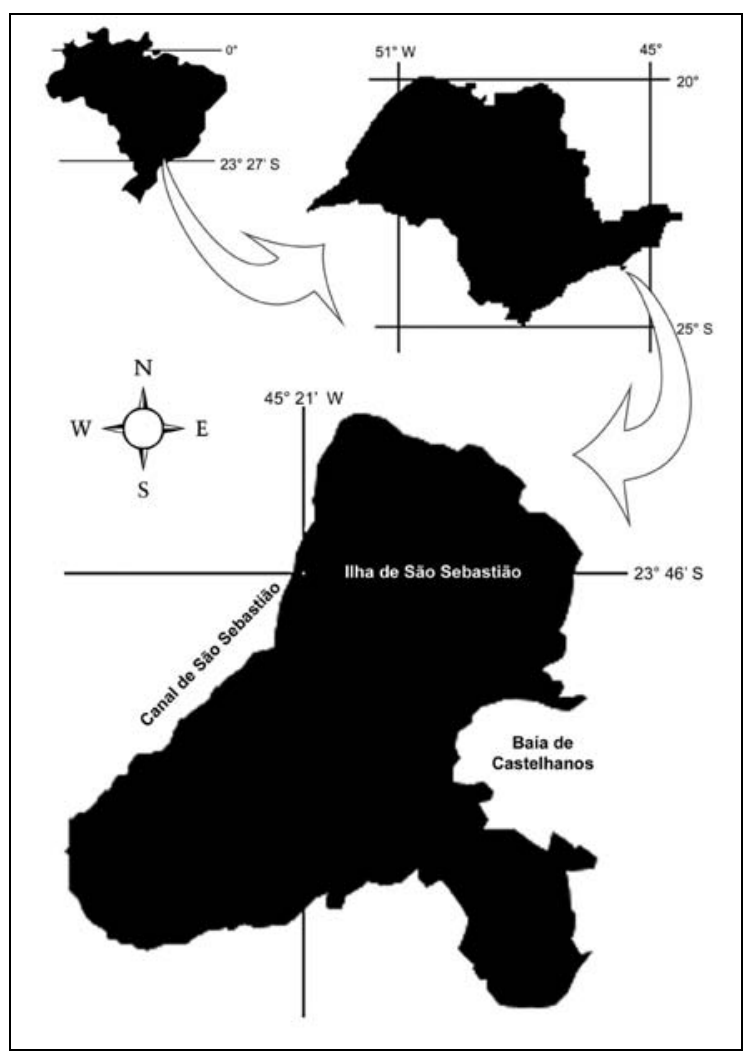

Figura 1 - Localização da área de estudo no contexto nacional e estadual. Org.: M. A. Milanesi (2007). 
A população fixa é de 26 mil habitantes e a flutuante, para férias, feriados prolongados e festas populares pode ultrapassar a marca das 100 mil pessoas (IBGE, 2007). A atividade econômica tradicional é a pesca artesanal praticada pelas comunidades caiçaras, hoje isoladas do setor urbano. A vocação para o turismo é de suma importância para a economia local que, atualmente está baseada na exploração dos recursos marinhos, pesca comercial, esportes náuticos e turismo. Beneficiam-se dos royallties ambientais recebidos da Petrobrás, por conta do TEBAR, em São Sebastião (Figura 2), onde são estocados parte do óleo bruto importado pelo país e que tem causado inúmeros acidentes ambientais nas últimas décadas. Há, contudo, políticas fomentadoras de desenvolvimento que estão atraindo fluxos de investimentos de diversas ordens, no intuito de fomentar a preservação de seu patrimônio natural, regular a atividade turística e garantir sua qualidade de vida de sua população.

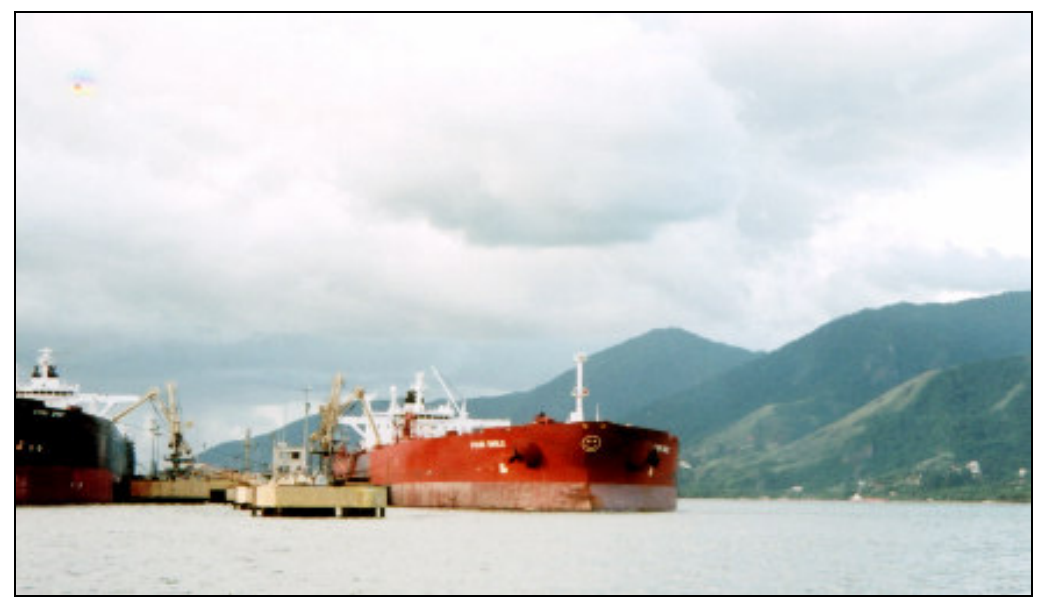

Figura 2 - Vista do ancoradouro do TEBAR da PETROBRÁS, no Canal de São Sebastião, com o setor norte de llhabela em segundo plano.

Org.: M. A. Milanesi (2005).

A Ilha de São Sebastião (Figura 3) possui relevo planáltico de orientação geral SW-NE em seu comprimento máximo (aproximadamente $27 \mathrm{~km}$ ). Apresenta desníveis altimétricos acentuados, acima dos $1300 \mathrm{~m}$, encostas com inclinação em 
torno de $30 \%$ e pequenas planícies. A vegetação de Mata Atlântica, que recobre a ilha apresenta-se em diversos estágios de desenvolvimento.

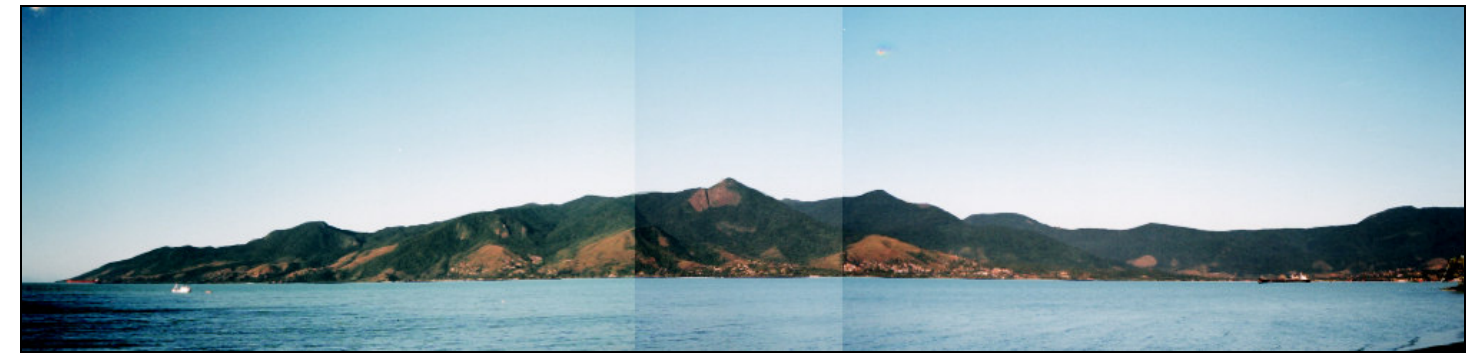

Figura 3 - Fotomontagem da vista da vertente continental da ilha, setor norte - centro, a partir da cidade de São Sebastião (01/08/2005, 16h).

Org.: M. A. Milanesi (2005).

O uso do solo urbano reflete a influência do relevo na reduzida malha viária da ilha. A principal via é a SP-131, que liga o norte ao sul, onde se observa uma intensa ocupação ao longo da orla, defronte ao canal e ao continente. Entre a Bacia do Perequê e a Vila, a mancha urbana é concentrada, alcançando também os primeiros morros até aproximadamente $200 \mathrm{~m}$ de altitude, no limite altimétrico do PElb, dispersando-se nas direções norte e sul. A morraria interior é ocupada pela vegetação. As áreas urbanas na Figura 4 são identificadas pelo tom róseo e a vegetação, pelo verde. 


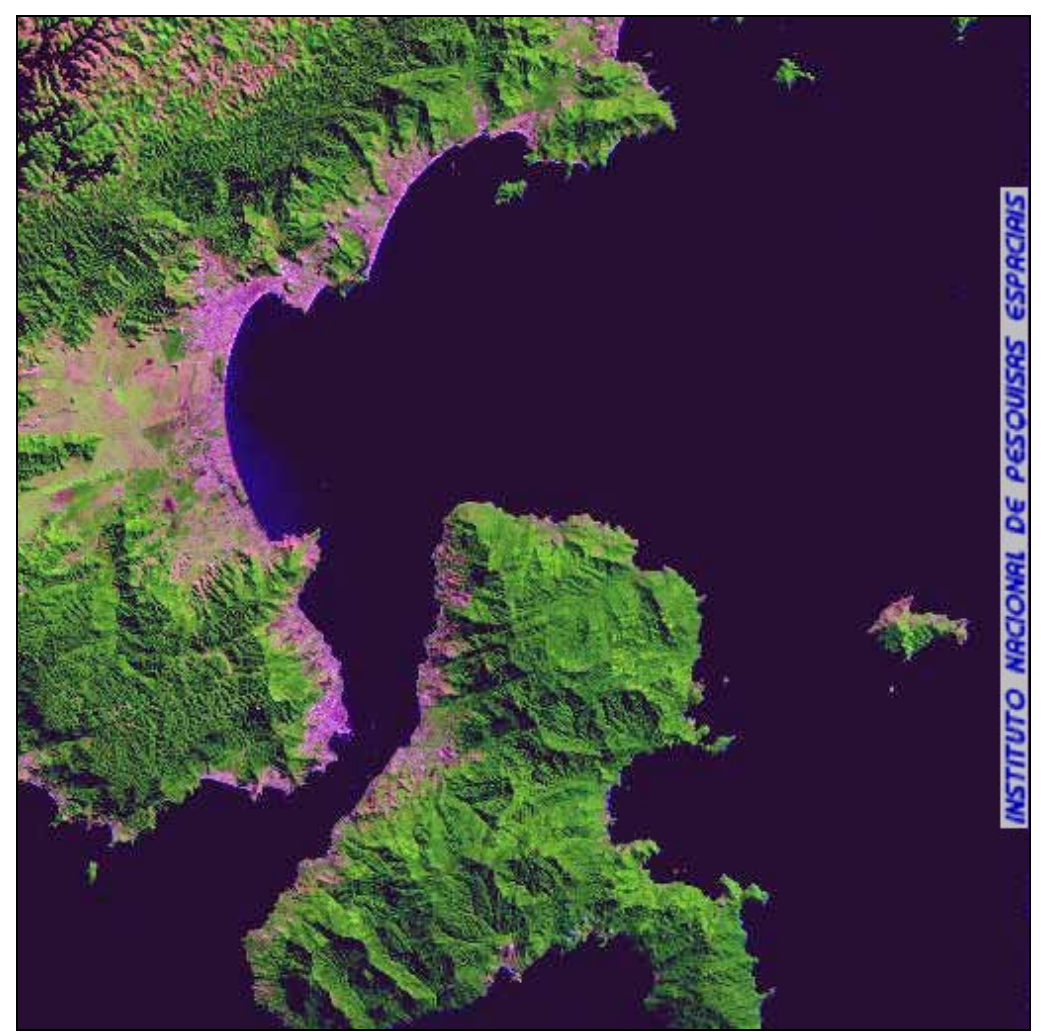

Figura 4 - Imagem da área de estudo, satélite Landsat 5TM, de 20 de agosto de 1988. Fonte: INPE (2006).

Outras áreas de planícies (Figura 5) são alcançadas por meio de transporte marítimo e trilhas, sendo ocupadas por comunidades caiçaras remanescentes, Praia de Castelhanos (na foto), Bonete e Enchovas, para citar as maiores. Nota-se, ainda, nessa imagem a presença de nuvens cumuliformes (cumulus humilis) baixas, formadas basicamente a partir do processo de evapotranspiração com base abaixo dos $300 \mathrm{~m}$ de altitude. 


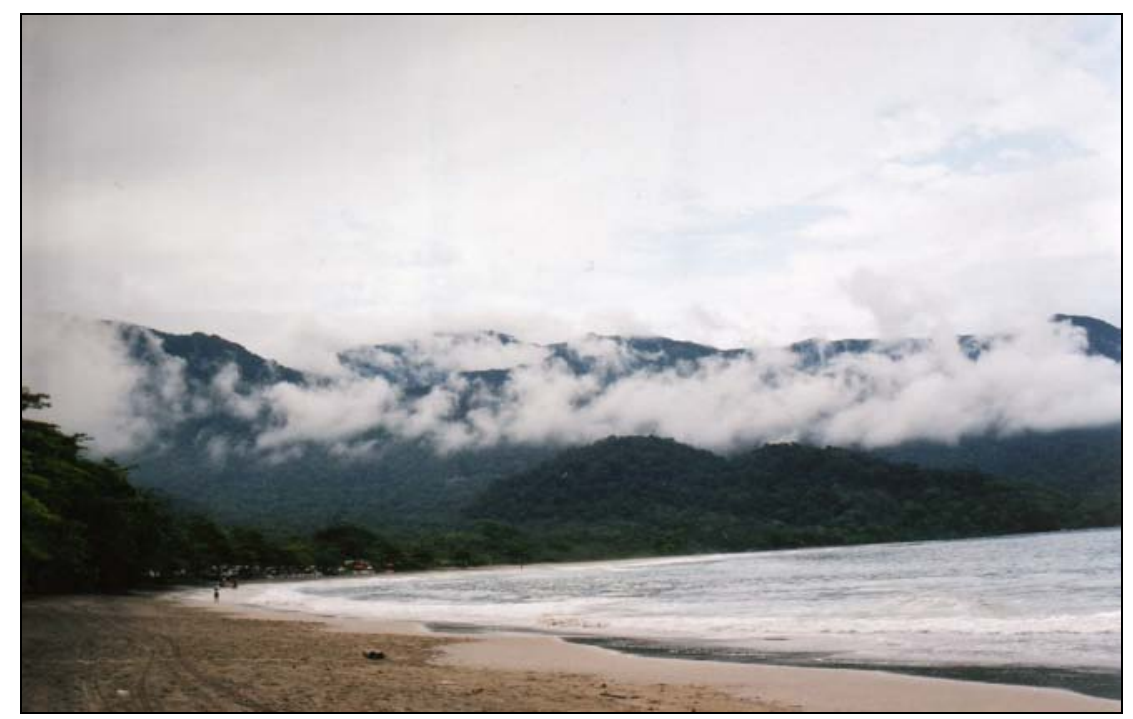

Figura 5 - Imagem da Praia de Castelhanos e a estreita área da planície litorânea que ocupa (01/11/04, 13h).

Org.: M. A. Milanesi (2004).

A Figura 6 apresenta parte da área dos municípios de São Sebastião e Ilhabela, o canal de São Sebastião, o TEBAR, a Estrada de Castelhanos, na porção central da ilha e a localização dos 13 pluviômetros experimentais utilizados na coleta de dados. A base utilizada é parte da carta topográfica do IBGE, de São Sebastião.

A Estrada de Castelhanos é uma importante via de ligação da ilha na direção W-E, em suas duas grandes vertentes: continental e oceânica. É a única ligação terrestre entre o setor urbanizado da ilha e as comunidades caiçaras de leste, a Estrada de Castelhanos corta o trecho central da ilha, num percurso de aproximadamente $22 \mathrm{~km}$, onde as altitudes variam entre 0 e $690 \mathrm{~m}$ e as declividades superam os $30 \%$, privilegiando três compartimentos geomorfológicos distintos: planície, vertente e divisor de águas. Sua maior extensão encontra-se inserida na área do PElb, não dispondo de calçamento ou pavimentação. Também é utilizada por "jipeiros" locais que dão suporte à atividade turística local transportando turistas e mantimentos até a Praia de Castelhanos. 


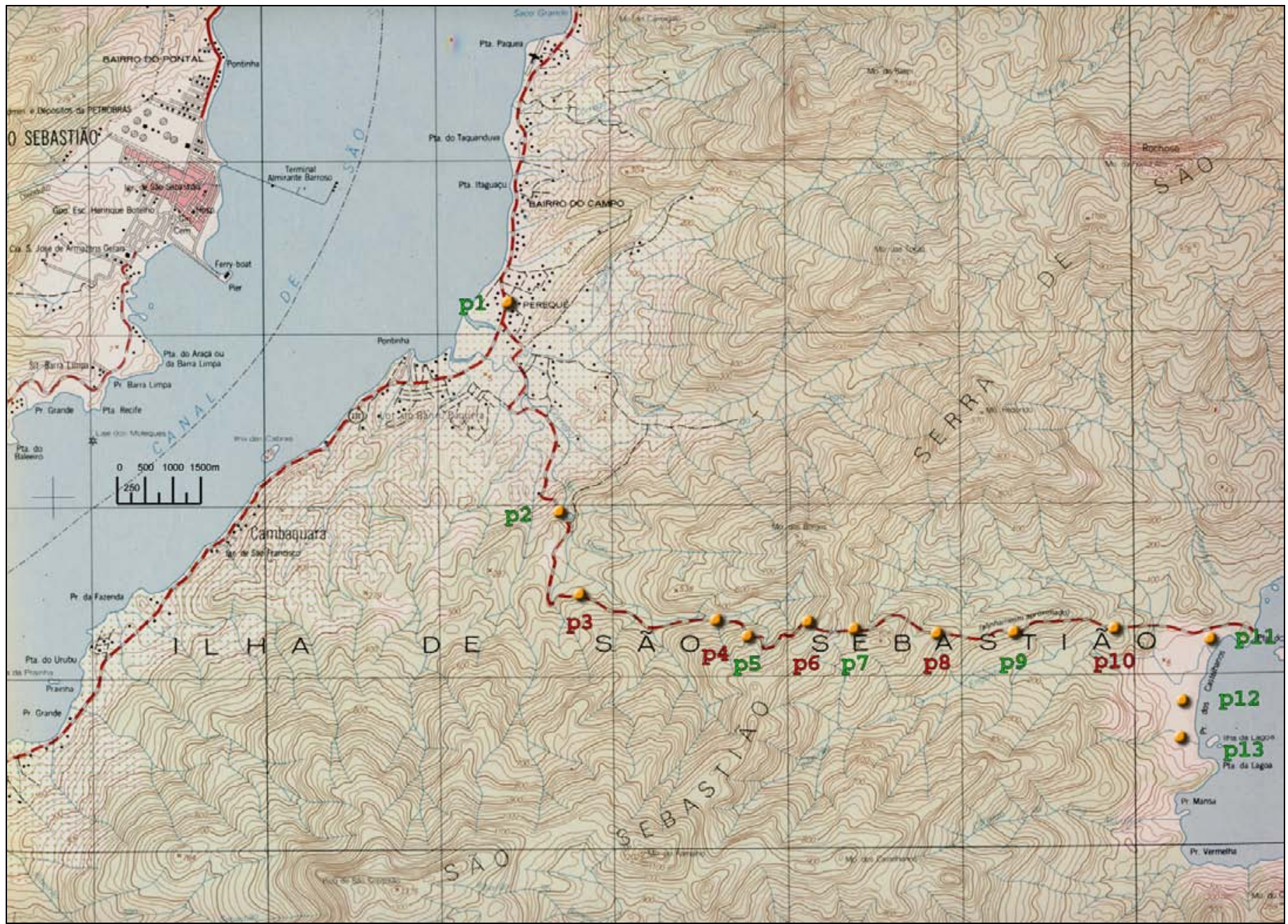

Figura 6 - Parte da carta topográfica São Sebastião e a localização dos pluviômetros ao longo da Estrada de Castelhanos.

Fonte: IBGE (1977). 
Ainda com relação à Figura 6 e a identificação dos postos pluviométricos utilizados cabe dizer que a proposta inicial da instalação de treze pluviômetros experimentais foi realizada, porém, alguns foram vandalizados e/ou furtados no decorrer da pesquisa, comprometendo a confiabilidade de suas observações. É o caso dos postos grafados em vermelho. Esses foram excluídos do universo de análise, restando aqueles grafados em verde, os oficiais aqui utilizados.

As características de traçado, elevação, declividade e comprimento naturalmente pesaram na preferência pela instalação dos postos pluviométricos para a coleta da chuva na Estrada de Castelhanos (Figuras 7 e 8), pois funciona como uma síntese do relevo ilhéu.

Pode ser observado na Figura 9, o perfil topográfico da ilha conforme a estrada, que realça a importância das altitudes, da orientação das vertentes e indicando o posicionamento dos pluviômetros (em verde aqueles oficiais e em vermelho aqueles descartados desta pesquisa). Foi de grande conveniência utilizá-la, pois a configuração das vertentes opostas pode ser expressa por meio de uma série diferenciada de indicadores da intensa dinâmica pluvial em quase toda sua de extensão solos expostos, deslizamentos, afloramentos rochosos e inúmeros lamaçais. 


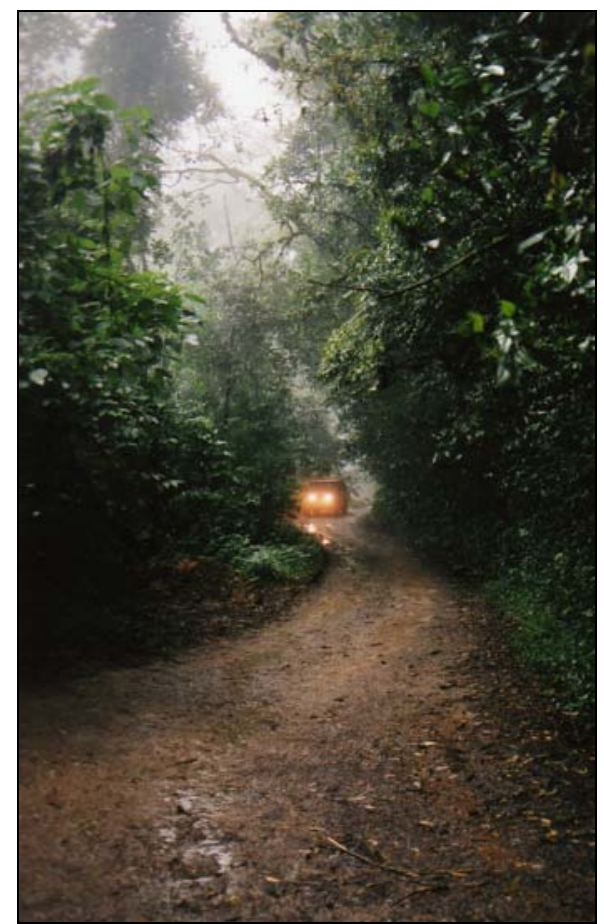

Figura 7 - Imagem da Estrada de Castelhanos, na Serrinha (divisor de águas) sendo trilhada por um jipe turístico em meio a um nevoeiro $(01 / 12 / 2004,14 \mathrm{~h})$.

Org.: M. A. Milanesi (2005).

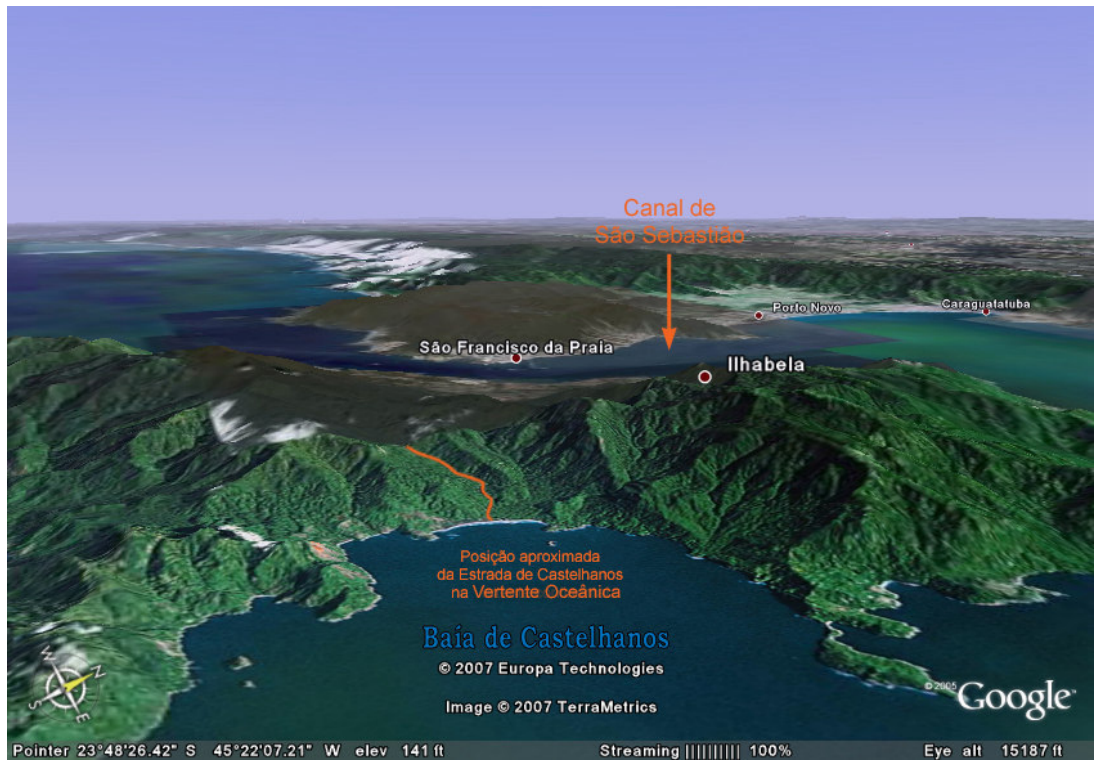

Figura 8 - Imagem da vertente oceânica da llha de São Sebastião e localização aproximada da Estrada de Castelhanos.

Fonte: Google Earth (2007)

Org.: M. A. Milanesi (2007). 


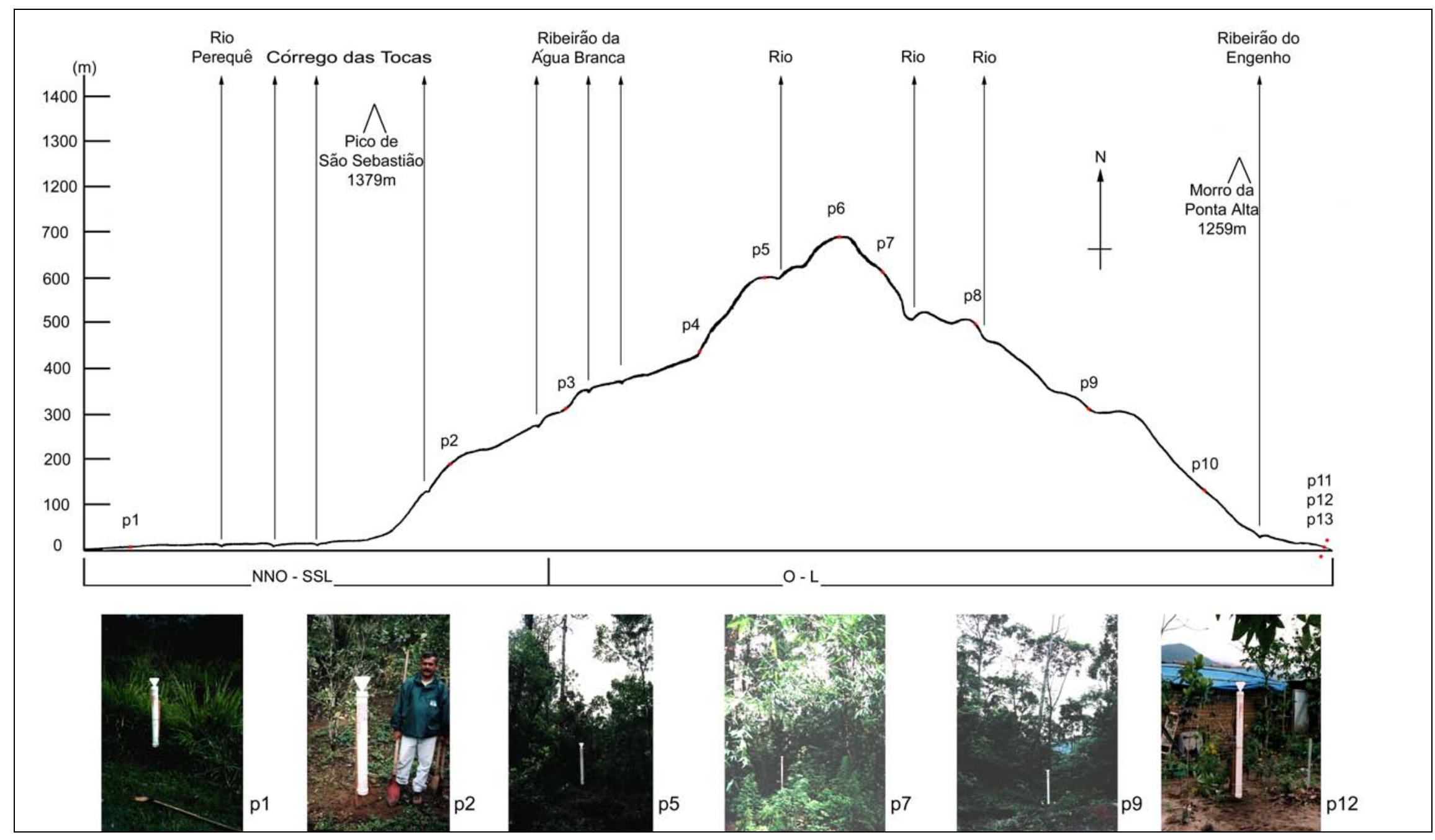

Figura 9 - Perfil topográfico da Estrada de Castelhanos e localização dos pluviômetros.

Fonte: IBGE (1977). 
A variabilidade pluvial e a fragilidade ambiental a que a ilha e a estrada, em particular, apresentam associa-se aos efeitos da atividade antrópica resultando em desequilíbrios, muitas vezes desastrosos, causando prejuízos naturais, sociais e econômicos.

A Figura 10 mostra a Estrada de Castelhanos sendo desobstruída de um deslizamento após evento de chuva intensa. Foram necessárias mais de 3 horas para conclusão do trabalho.

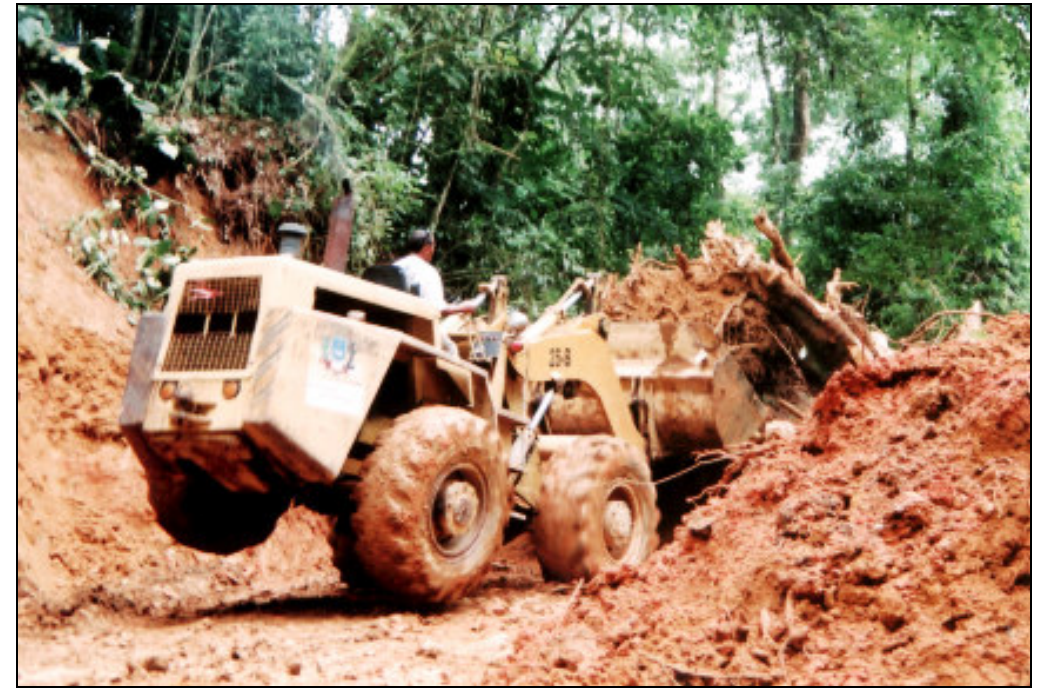

Figura 10 - Imagem da Estrada de Castelhanos sendo desobstruída de um deslizamento, após episódios de chuva intensa $(01 / 04 / 2005,12 \mathrm{~h})$.

Org.: M. A. Milanesi (2005). 


\subsection{Caracterização natural}

A área de estudo constitui-se no espaço de ocorrência da paisagem que Ab'Saber (2003) classifica como "mares de morros" no domínio tropical atlântico. Apresenta, de forma geral, clima tropical de alta influência oceânica e orográfica (Serra do Mar), situação que Ihe confere grande biodiversidade fauno-florística, representada pela existência da Mata Atlântica, formação florestal que se estende por boa parte do litoral brasileiro. Comparativamente com outros continentes e em mesmas latitudes, possui condições climáticas semelhantes: é quente e úmida, como a llha de Madagascar, na África.

No contexto geomorfológico, está inserida em área de dobramentos antigos do Atlântico, sobre rochas do Pré-Cambriano, fortemente desgastadas pela erosão, porém, apresentando altitudes muitas vezes superiores a 1000m (ROSS, 1996). De relevo escarpado alto e abrupto é identificado em grande extensão do litoral brasileiro, sobretudo no sul-sudeste como Serra do Mar. É uma importante forma de relevo, responsável pelas maiores altitudes encontradas na linha da costa e por abrigar parte da Mata Atlântica remanescente.

Cruz (1986), em estudo sobre a preservação das vertentes da Serra do Mar apresenta uma caracterização da dinâmica natural e antropogênica dos processos geomorfológicos na área de Caraguatatuba (SP). Segundo a autora, é no Litoral Norte paulista que as escarpas da Serra do Mar mais se aproximam do litoral, apresentando altitudes superiores a 1000m em seu contato com o Planalto Atlântico, que "de longe" lembram grandes muralhas. À base das escarpas estão as planícies litorâneas bastante recortadas e pouco desenvolvidas em área e, por vezes, 
entremeadas por costões rochosos e picos. No caso de Caraguatatuba, há um recuo maior da serra, deixando a baixada desenvolver-se e formando um conjunto geomorfológico costeiro amplo voltado para leste, o "bolsão". Em São Sebastião, limitam-se as planícies por esporões que avançam contra o mar em costões, a partir dos 600 - 700m, as planícies "de bolso". Os picos dos maciços alcalinos de Ilhabela atingem até 1202m. Têm como características forte amplitude topográfica, aprofundamento dos vales pela drenagem e altas declividades, superiores a $22^{\circ}$. A autora propõe que essas encostas escarpadas sejam castigadas freqüentemente pela elevada umidade provinda do oceano, sob a forma de neblinas e chuvas, provenientes de massas úmidas oceânicas e passagens de frentes frias.

Troppmair (1995) caracteriza a vegetação da região, a Mata Atlântica (Figura 11), como do tipo floresta pluvial de encosta, com barlavento condicionado aos ventos alíseos, que vem do mar. A encosta é atuante na formação das chuvas orográficas (entre 2000 e $3000 \mathrm{~mm} / \mathrm{ano}$ ), devido à declividade acentuada. Predominam os solos rasos (litosolos), sujeitos a deslizamentos, quando desmatados. A inclinação das vertentes mais ensolaradas favorece uma menor competição pela luz, apresentando árvores menor porte, em torno de $20 \mathrm{~m}$. De alta biodiversidade, sua heterogenia de espécies é marcada pela presença de leguminosas (ingá, angico), bigoneáceas (ipês), lauráceas (abacateiro, imbuia), mirtáceas (goiabeira, pitangueira), assim como as epífitas (orquídias e lianas) entre outras. Os estratos mais baixos, gramíneas e arbustos mantêm competição constante pela luz. A fauna de grande porte praticamente foi extinta pela ação do homem. 


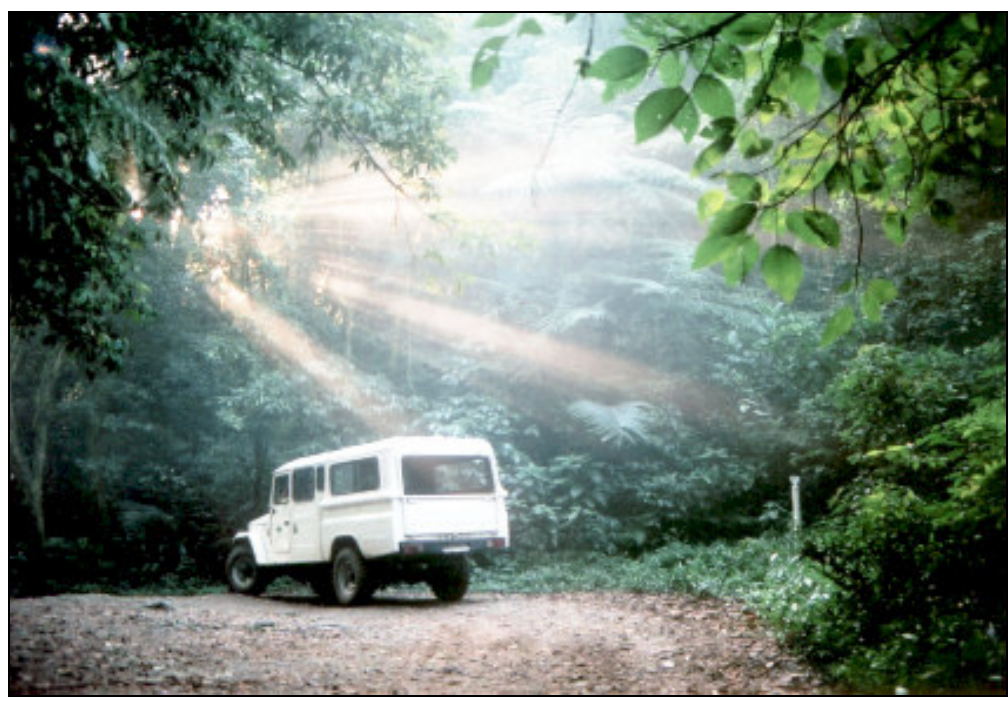

Figura 11 - Imagem da Serrinha (divisor de águas) e do posto $6(690 \mathrm{~m})$, na Estrada de Castelhanos (01/05/2005, 15h).

Org.: M. A. Milanesi (2005).

O paralelo $23^{\circ}$ está associado a um acentuado dinamismo meteorológico responsável pela atuação de sistemas atmosféricos secundários ou regionais de características distintas: os extratropicais (frios, originados nas altas e médias latitudes do hemisfério sul) e os intertropicais (quentes, originados tanto no interior do continente como no oceano em latitudes subtropicais), que geram um tipo de tempo muito comum no estado, a passagem de frentes (MONTEIRO, 1973).

Segundo a classificação climática de Monteiro (1973) para o Estado de São Paulo baseada na participação das massas de ar na gênese das chuvas, o litoral é controlado por algumas das mais importantes correntes de circulação atmosférica da América do Sul. As correntes de sul (responsáveis pela Massa Polar Atlântica (MPA) e dinâmica de frentes como a Frente Polar Atlântica (FPA)), as correntes de lestenordeste (Massa Tropical Atlântica (MTA)) e em menor freqüência pelas correstes de oeste-noroeste (Massa Tropical Continental (MTC)). O diferencial entre essas massas de ar é dado pela temperatura e pelo teor de umidade em seu interior, que garante a possibilidade da chuva. Cada uma delas possui uma área de domínio e 
atua com intensidades variadas, segundo as estações do ano e os centros de pressão a que estão vinculadas, além de outros controles de escala hemisférica.

Conforme esta classificação, Ilhabela está complexamente inserida no limite teórico entre aquelas duas importantes regiões climáticas do estado, que em sua feição litorânea, apresenta algumas características elementares como a existência de um período seco pouco nítido durante o outono-inverno, quando a orografia pode ser realçada e, sobretudo, o choque entre massas de ar diferenciadas. Esses choques são os responsáveis pela formação de frentes e dentre elas, a FPA é liderança na gênese da chuva regional.

A alternância entre a ação desses dois sistemas atmosféricos e conseqüentemente, das massas de ar a eles associadas, aliados às características do relevo, da vegetação e a proximidade do oceano influenciam na formação e intensificação de chuvas e na sua distribuição espacial regional e afirma a variabilidade climática a que a área está sujeita (MONTEIRO, 1973).

Para Conti e Ângelo Furlan (1998), o regime pluviométrico tem em sua gênese a atuação das massas polares $(\mathrm{mP})$ que dinamiza a frente polar atlântica (FPA), caracterizando verões chuvosos e os invernos com pequenos períodos de estiagem, onde as temperaturas médias anuais ficam em torno de $24^{\circ} \mathrm{C}$ e a pluviosidade média anual acima dos $1500 \mathrm{~mm}$, com valores superiores nas encostas a barlavento.

O Instituto Brasileiro de Geografia e Estatística (IBGE) talvez seja responsável pela primeira informação cartográfica oficial acerca da distribuição espacial da chuva da área de estudo, quando da publicação da Carta de Isoietas Anuais da Região mais Chuvosa do Brasil (sem data), entre os anos de 1914 e 1938 . Os valores da $1^{\text {a }}$ Normal Climatológica (sic) estão aqui representados no trecho da carta que inclui a área de estudo (Figura 12). Podemos notar que a área do canal e da cidade de São 
Sebastião está inclusa na isoieta de $1500 \mathrm{~mm}$ de chuva anual e que na medida em que as altitudes tornam-se maiores, aumentam os valores de chuva, estando as áreas mais altas inclusas nas isoietas 2000 a 2500mm. Chamamos a atenção para o fato da inexistência de postos pluviométricos na ilha neste período, logo a cartografia histórica das chuvas da área é teórica. E desconhecemos até o momento, pesquisas que comprovem a esta cartografia ou intenções que se proponham a realizá-la.

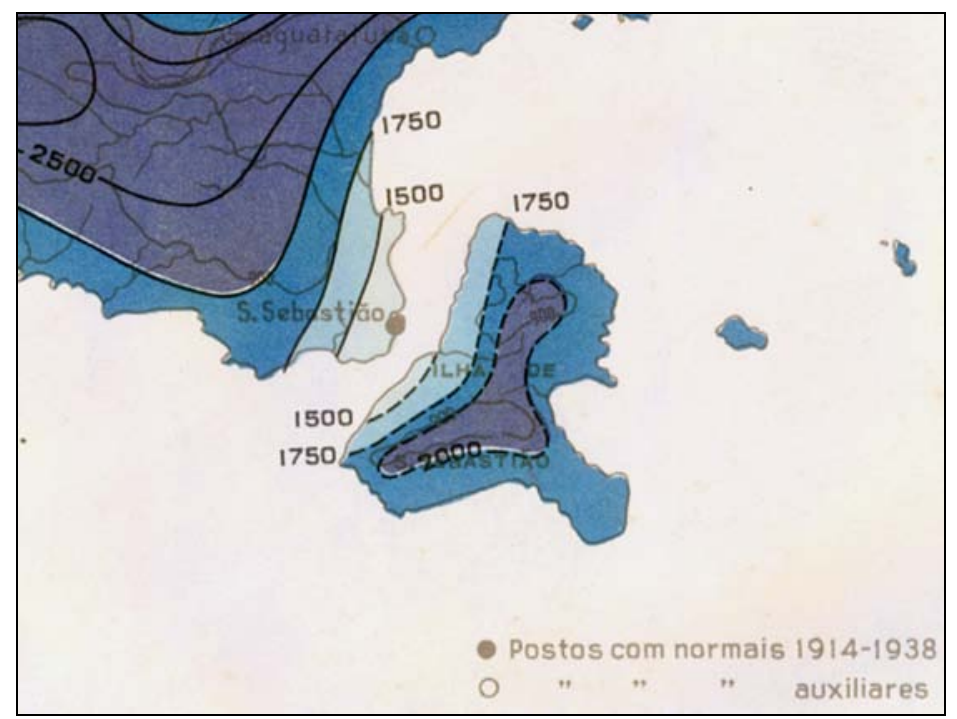

Figura 12 - Parte da Carta de isoietas da região mais chuvosa do Brasil.

Fonte: IBGE (s/d)

A imagem do satélite sino - brasileiro CBERS 2 (Figura 13), de 20 de março de 2006, apresenta a porção sudoeste do litoral Norte de São Paulo, correspondente ao município da Bertioga e da área de estudo. Pode-se notar pela imagem registrada às 13h 02min 51s - GMT (10h 02mim 51s - HL), a nebulosidade que contorna boa parte da face leste da ilha, em forma de arco que acompanha o relevo. Em sua porção sul nota-se uma concentração de nuvens, também relacionada ao relevo, pois aí se encontra o Maciço de São Sebastião, a parte mais elevada desta área. 


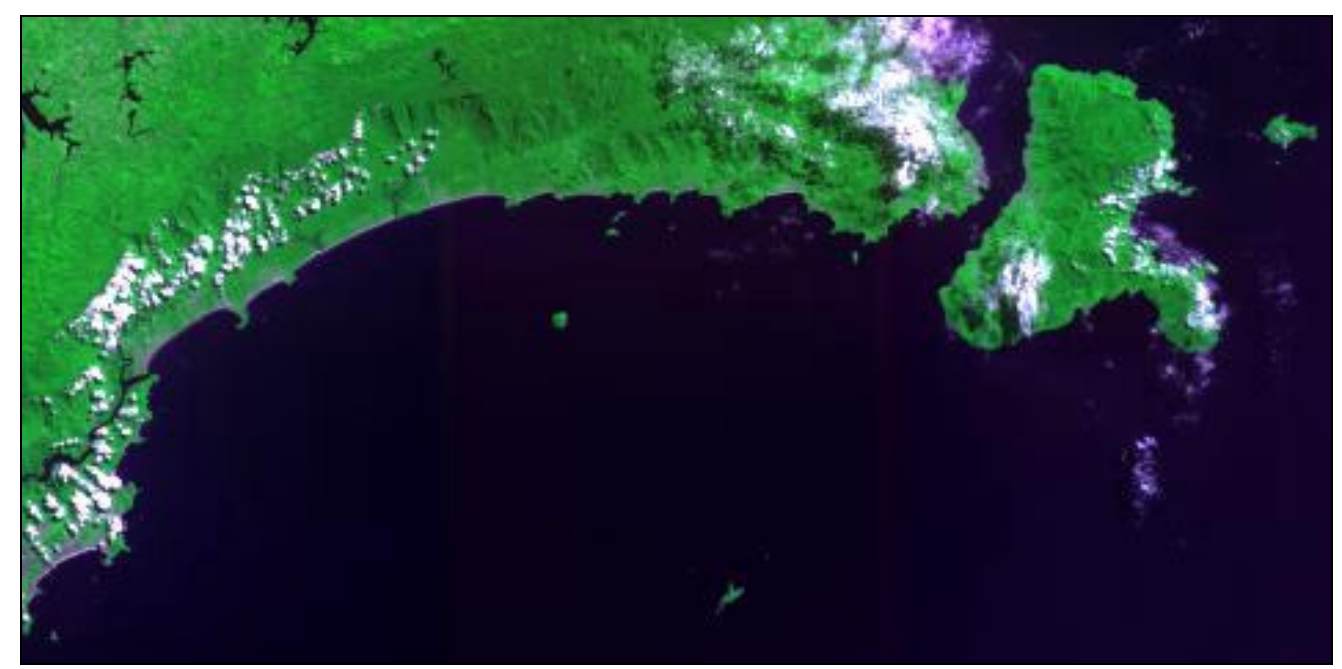

Figura 13 - Imagem da área de estudo, satélite CBERS2 CCD, de 20 de março de 2006, com nebulosidade orográfica.

Fonte: INPE (2006)

\subsection{Climatologia regional}

Segundo a classificação climática de Köppen, a faixa litorânea do Estado recebe a classificação Af, caracterizada pelo clima tropical chuvoso, sem estação seca com a precipitação média do mês mais seco superior a $60 \mathrm{~mm}$. Em pontos isolados do litoral, como na área de estudo, ocorre o tipo Am, que também é descrito como clima tropical chuvoso, com inverno seco onde o mês menos chuvoso tem precipitação inferior a $60 \mathrm{~mm}$. O mês mais frio tem temperatura média superior a $18^{\circ} \mathrm{C}$ (sic) (CENTRO DE PESQUISA METEOROLOGICA E CLIMATICA APLICADA A AGRICULTURA - CEPAGRI, 2007)

Para a apresentação da climatologia regional da área de estudo nos baseamos nos dados da $3^{a}$ Normal Climatológica (1961 a 1990), publicada pelo Instituto 
Nacional de Meteorologia (INMET), em 1992, para o posto meteorológico Ubatuba $(\mathrm{SP})$.

\subsubsection{Insolação e Nebulosidade}

A Figura 14 apresenta as normais climatológicas de insolação e nebulosidade para o posto Ubatuba. Ao longo do ano nota-se uma elevada amplitude na insolação apresentando um máximo de 110 horas de brilho solar, em julho, e um mínimo de 73,3 horas, em outubro. Quando comparada à nebulosidade, notamos uma nítida correlação negativa. Na medida em que a primavera se aproxima, a nebulosidade aumenta alcançando um pico de oito décimos de céu encoberto em outubro, fazendo com que o número de horas de brilho solar diminua. $\mathrm{O}$ inverso pode ser notado durante o restante do ano, a partir do verão até o final do inverno sobressaem-se as horas de brilho em virtude da redução da nebulosidade. A proximidade da serra e do oceano somada às altas temperaturas garante um intenso processo de evaporação das águas e formação de nuvens. Ao longo do ano, os dias invariavelmente apresentam algum tipo nebulosidade, ocupando uma área média mínima de 4,5/10 do céu. 


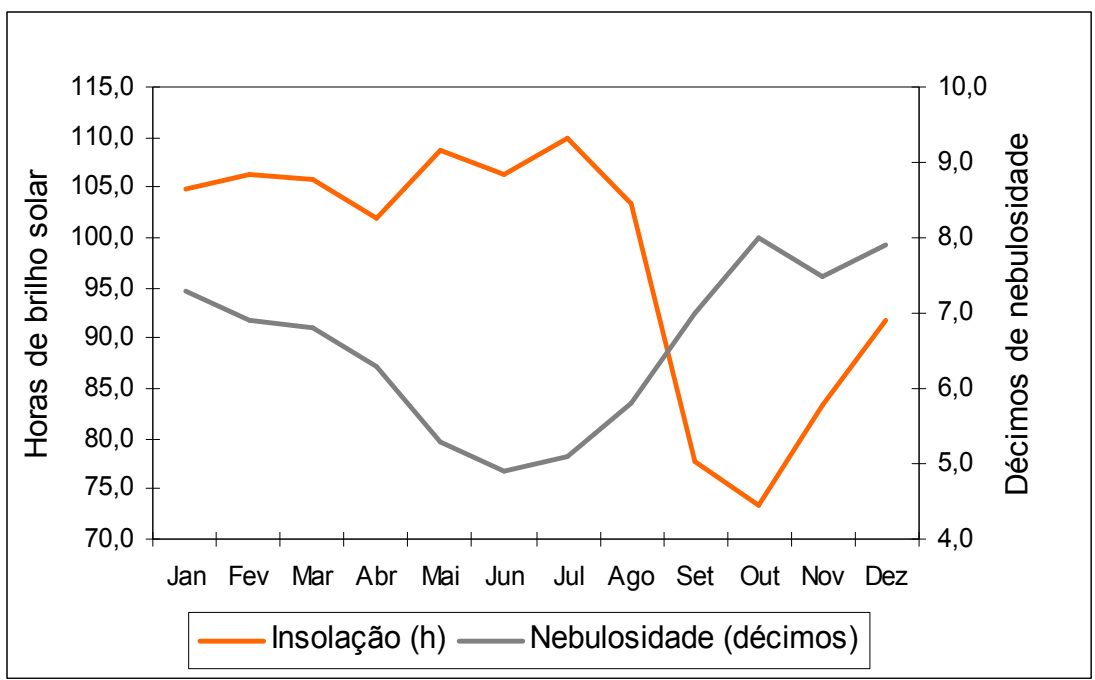

Figura 14 - Normais de insolação e nebulosidade para o posto Ubatuba, entre 1961 e 1990. Fonte: INMET (1992).

\subsubsection{Temperatura do ar}

As normais de temperatura do ar para o mesmo período em Ubatuba (Figura 15), apresentam as temperaturas máximas e mínimas (normais), além de sua média compensada.

Observa-se uma alta correlação positiva nas distâncias entre os valores. As médias compensadas de temperatura variam de $25^{\circ} \mathrm{C}$, em fevereiro e $18^{\circ} \mathrm{C}$, em julho. A amplitude térmica entre as temperaturas máximas é da ordem de $6,2^{\circ} \mathrm{C}$, com valor máximo em fevereiro $\left(30,3^{\circ} \mathrm{C}\right)$. A amplitude térmica das mínimas é da ordem de $8^{\circ} \mathrm{C}$, com valor mínimo em julho $\left(12,8^{\circ} \mathrm{C}\right)$. A amplitude térmica é uma marca dos climas tropicais, pode ser reduzida em função da maritimidade, que regula o clima regional. 


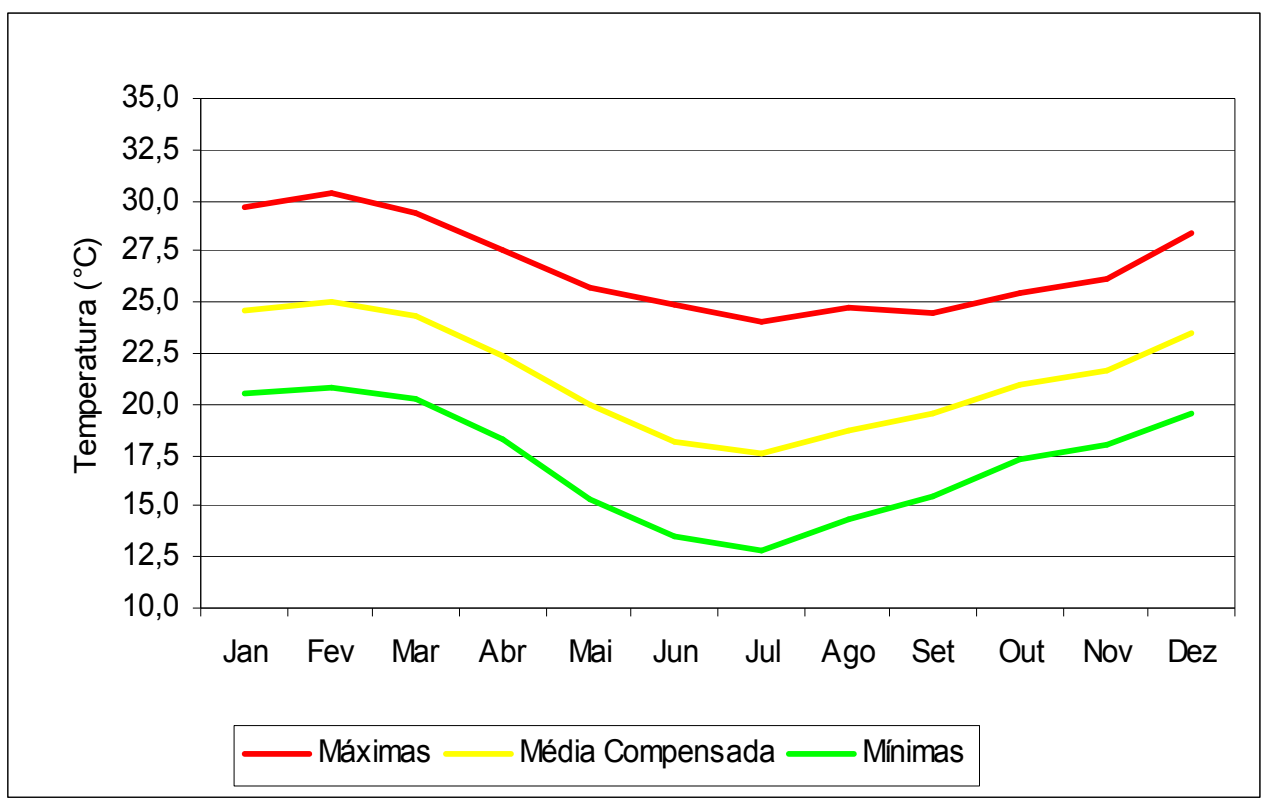

Figura 15 - Normais de temperatura para Ubatuba, entre 1961 e 1990.

Fonte: INMET (1992).

\subsubsection{Precipitação}

$\mathrm{Na}$ Figura 16 é representada a normal para totais mensais e máximos acumulados de chuva em $24 \mathrm{~h}$ nos respectivos meses. O primeiro fato a chamar a atenção é a existência marcada do regime anual. Nos meses invernais de julho, agosto e setembro a precipitação acumulada fica em torno e abaixo de $100 \mathrm{~mm}$, o que é relativamente reduzido se comparado aos meses de primavera e verão, entre outubro e abril, quando são observados valores superiores a $220 \mathrm{~mm}$. Os valores médios em dezembro e janeiro representam o triplo dos valores médios durante o inverno

Com relação à altura de chuva acumulada em $24 \mathrm{~h}$, nos meses de abril, junho, julho, novembro e dezembro, quando superam as normais mensais, é que se pode 
perceber o retorno esporádico dos eventos de chuva intensa. Tais eventos como frentes reflexas, oclusas, instabilidades de noroeste e ondas de leste, entre outros, de atuação regrada conforme as estações do ano devem ser considerados para sua explicação.

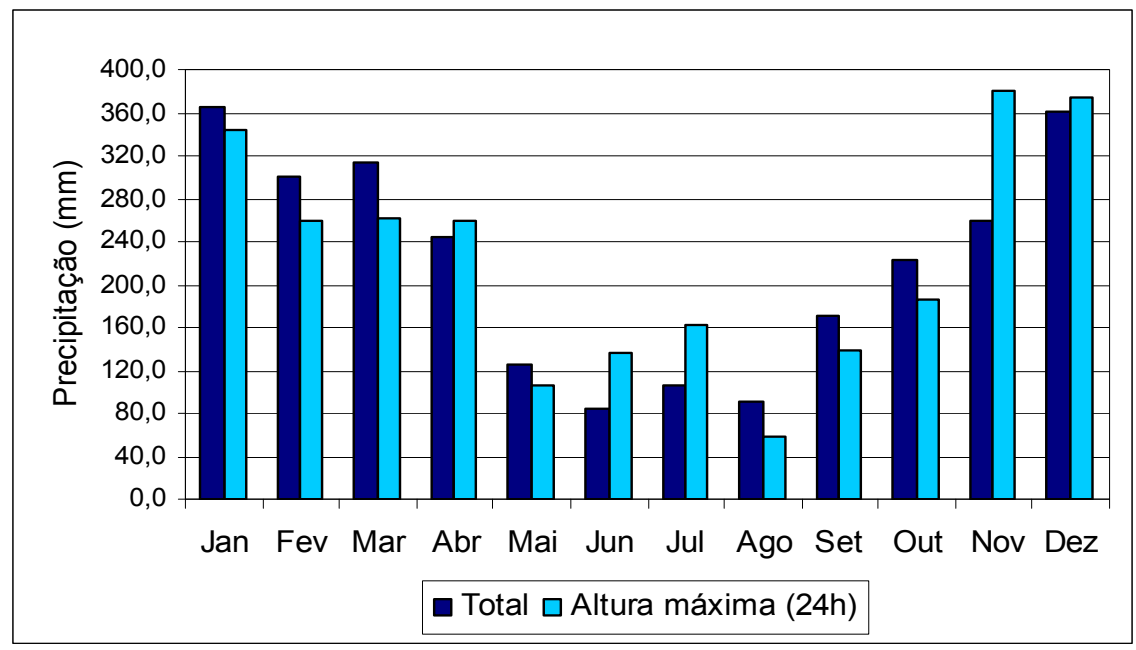

Figura 16 - Normais de precipitação e chuva máxima em 24h para o posto Ubatuba, entre 1961 e 1990.

Fonte: INMET (1992).

\subsubsection{Balanço Hídrico Climatológico}

O balanço hídrico climatológico fornecido pelo CEPAGRI está representado na Figura 17 e demonstra com clareza a contabilidade da água no solo da ilha ao longo do ano. É fator de influência desde para o desenvolvimento de uma cultura vegetal até a dinâmica florestal e climática de uma localidade.

Apresenta alta correlação com os dados de chuva de Ubatuba. Pode-se perceber nos meses de inverno e primavera (os menos úmidos), retiradas de água acima da capacidade do solo de retê-la gerando a deficiência hídrica para o período (deficit de $12 \mathrm{~mm}$, em setembro). O início do verão (e o retorno da estação chuvosa) é responsável pela reposição das perdas dos períodos anteriores. O final do verão e 
praticamente todo o outono quando correlacionados às maiores quantidades precipitadas de chuva, indicam excesso de água no solo (em média, acima de 30 mm, porém, diminuindo com a proximidade do inverno).

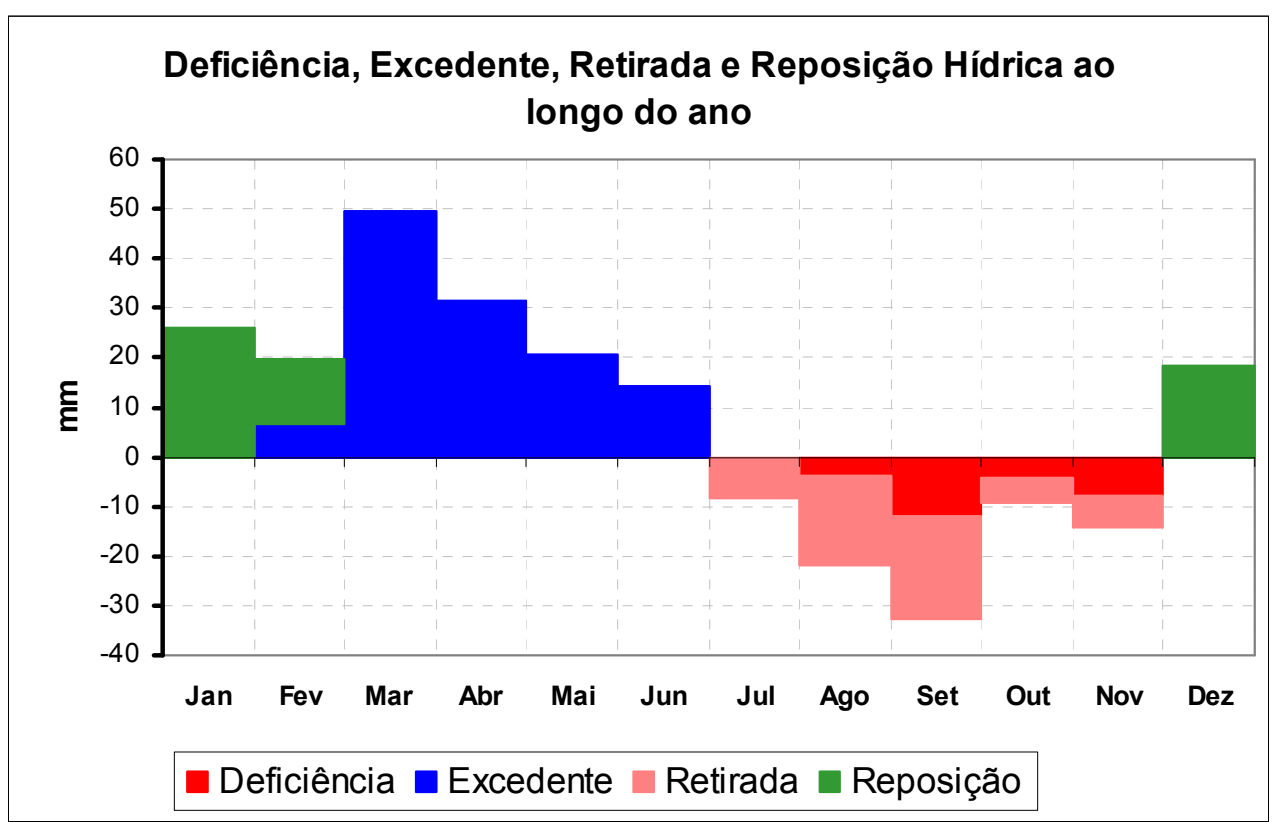

Figura 17 - Balanço hídrico climatológico normal de llhabela.

Fonte: CEPAGRI, (2006).

\subsubsection{Dinâmica Regional da Pluviosidade}

Monteiro (1973), em seu Atlas Pluviométrico, caracteriza o litoral com média anual de $1400 \mathrm{~mm}$ por ano e suas serranias com quantidades de chuva superiores a 2000mm/ano. A Ilha de São Sebastião, por sua vez, apresenta na vertente oceânica quantidades superiores a $1700 \mathrm{~mm} / \mathrm{ano}$ e, na vertente oposta, inferiores, sendo que nas áreas de maior altitude pode atingir a média de $2000 \mathrm{~mm} / a n o$. O período da primavera-verão é marcado pela atuação da MTA, produtora de bom tempo e, das ondas de leste, com maior potencial de chuva. Já no outono-inverno, as chuvas de 
origem frontal são o diferencial representando mais de $50 \%$ das chuvas no litoral. Apresenta ainda, intensidade média de chuva entre 60 a $80 \mathrm{~mm}$ acumulados em $24 \mathrm{~h}$ e, eventos de chuva concentrados entre 100 e 150 dias por ano.

Monteiro (1969), em estudo sobre a FPA, conclui sobre a frontogênese (criação de frentes), ser esta um acontecimento lógico entre o choque de duas massas de ar, porém, individualmente tendendo a produzir bom tempo. No litoral paulista normalmente ocorre a frontólise (estágio final da existência de um sistema de frente), e por conta disso, área de teórica de oclusão e reflexão do eixo da frente, habitualmente, pouco geradores de chuva. Dessa forma, entende-se que o aquecimento basal e o efeito orográfico poderiam contribuir de alguma forma com algum teor de precipitação. Ressalta ainda que nas proximidades da área de estudo, os valores de chuva são muito elevados e podem atingir níveis anuais superiores a $3000 \mathrm{~mm}$.

Monteiro, em 1973, classifica o litoral em duas grandes feições climáticas. A primeira classificação, Litoral e Planalto Atlântico Norte, teoricamente, corresponde à porção norte da ilha. É caracterizada por 30 a 40\% de atuação das massas polares (incluindo as passagens da frente polar), ao longo do ano. As quantidades de chuva de outono-inverno são em torno de $500 \mathrm{~mm}$ e aquelas de primavera-verão, superam os $2000 \mathrm{~mm}$. Na primavera-verão, as ondas de leste interagem com o setor nortenordeste da ilha, podendo gerar chuvas orográficas. A segunda classificação, Litoral e Planalto Atlântico Sul, correspondente à porção sul da ilha, apresenta maior porcentagem na atuação das massas polares e conseqüentemente, mais chuva. $O$ relevo também exerce importante influência, tanto regional dada a orientação do trecho entre o Guarujá e São Sebastião (leste-oeste), sua elevação e proximidade ao oceano, chega a atingir precipitações anuais $4500 \mathrm{~mm}$, quanto local. Por 
analogia, o relevo do sul da ilha também poderia responder pela intensificação das quantidades de chuva observadas no inverno.

Observamos, de forma ampla, ao longo da série histórica analisada na região da área de estudo a presença constante de uma densa cobertura de nuvens, associada certamente às temperaturas elevadas (acima de $20^{\circ} \mathrm{C}$ ), em ao menos 6 meses do ano, que, aliadas à presença de baixas pressões predominantes no verão, aos efeitos da maritimidade e à intensa evapotranspiração vegetal, pressupõem, nesta estação, concentração de elevados valores pluviométricos e à existência, não de um período seco, mas, de um período menos úmido que caracteriza o inverno da região, invariavelmente sujeito às incursões das massas polares.

\subsection{Pluviometria regional}

Segundo Milanesi (2004), por meio da análise das séries históricas totais (de diversos períodos) de precipitação de sete postos pluviométricos do DAEE (Figura 18), instalados em situação de exposição e abrigo aos fluxos de ar predominantes nos municípios da região do litoral norte paulista, apontam para uma variação espacial entre 1300 a $2300 \mathrm{~mm}$ anuais. 


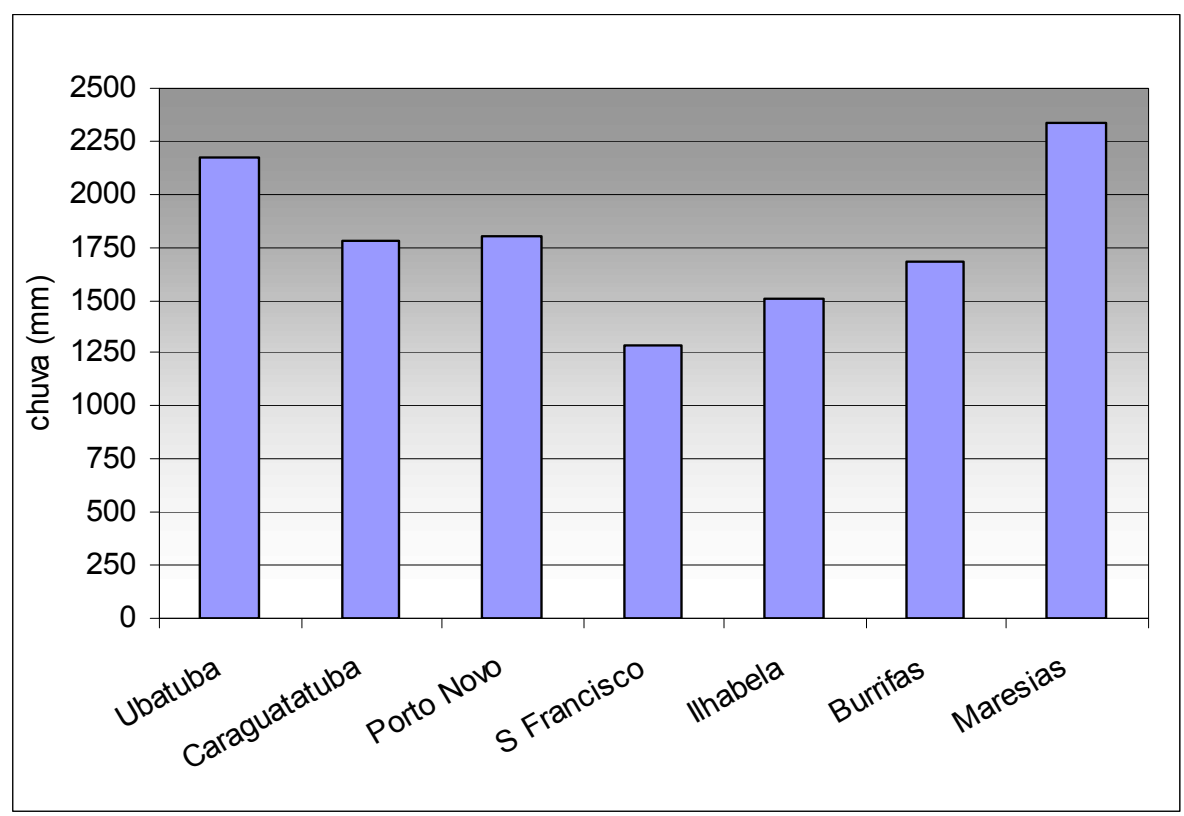

Figura 18 - Média climatológica do acumulado anual da precipitação para os postos do DAEE Ubatuba, Caraguatatuba, Porto Novo, São Francisco, Ilhabela, Burrifas e Maresias.

Org.: M. A. Milanesi (2004).

Em situação de exposição estão os postos Maresias e Ubatuba, com médias superiores a $2000 \mathrm{~mm}$ anuais. Em posição intermediária, no continente estão Porto Novo e Caraguatatuba com $1750 \mathrm{~mm}$, em média e, na vertente continental da ilha, essa média é um pouco menor (1650mm), com dois postos ativos a sotavento. Em situação de abrigo absoluto está o posto São Francisco e apresenta média inferior a 1300mm. Essa variação é sem dúvida uma clara expressão da influência do relevo da ilha que barra a incursão dos ventos predominantes de SE, gerando a sombra de chuva.

Os registros mensais máximos de chuva de $838,7 \mathrm{~mm}$, no posto Ubatuba, 714 $\mathrm{mm}$, no posto Burrifas (sul da ilha), $664,1 \mathrm{~mm}$, em Maresias, até $600 \mathrm{~mm}$ nos postos de Ilhabela (centro), Caraguatatuba e São Francisco e, abaixo de $500 \mathrm{~mm}$, Porto Novo, acusam grande variabilidade tanto temporal, quanto espacial. 


\subsection{Climatologia local}

A principal característica climática da ilha é gerada por meio da interação entre os fluxos aerológicos regionais e as suas características topográficas (aspectos morfológicos do relevo): a elevada diferença da umidade relativa do ar perceptível em suas vertentes opostas.

Sant'anna Neto (1993), propôs sua classificação para os sistemas naturais costeiros do Estado de São Paulo, sob a visão geossistêmica. É formalizada por meio do cruzamento de informações dos fatores abióticos mais a vegetação regional, formadores da paisagem natural. O resultado dessa interação aponta para o clima, como o determinante das variações espaciais e temporais, conferindo a esta região, uma forte complexidade morfo-climática.

Para Sant'anna Neto (op. cit.) a Ilha de São Sebastião insere-se na unidade denominada Fachada Atlântica, onde os índices anuais de chuva variam entre 2000 a 3000mm, de forma mais ou menos homogênea. A exceção dessa homogeneidade se dá no eixo Ilhabela/ São Sebastião/ Caraguatatuba, propiciada pelas serras do Juqueriquerê e de São Sebastião, que retardam a passagem das frentes, de modo que a Ilha de São Sebastião contribui para a existência de uma "ilha de sombra de chuva" na fachada de Caraguatatuba, onde a média anual de pluviosidade é inferior a $1800 \mathrm{~mm}$.

A ilha é composta por dois maciços rochosos: Serraria, ao norte e São Sebastião, ao sul, limitados por um cólo a 690m de altitude - a "Serrinha" (divisor de águas), por onde passa a Estrada de Castelhanos. Dada sua expressão altimétrica, com destaque para os picos do Baepi $(1025 \mathrm{~m})$ e do Papagaio $(1307 \mathrm{~m})$, ambos ao 
norte da ilha e o Pico de São Sebastião, com 1379m a sul, a vertente voltada para o oceano atua como barreira para os fluxos atmosféricos dominantes, úmidos, provenientes do setor SE.

Essas correntes de ar na transposição da barreira elevam-se, resfriando e condensando o vapor d'água a barlavento, podendo gerar nuvens e chuva (orográfica). Do outro lado, na vertente continental, protegidos dos fluxos, agora descendentes (quentes e secos), há o surgimento de uma atmosfera local menos úmida, que caracteriza o efeito de sombra de chuva. Na Figura 19 registramos a porção central da vertente continental da ilha, em janeiro de 2005 , às $16 \mathrm{~h}$. Pode-se notar a ocupação urbana nas altitudes menores em avanço sobre os morros e dois conjuntos de nuvens, cirrus na alta atmosfera e stratus sobre a ilha, quando da transposição do divisor de águas, possivelmente formada pela frente de brisa.

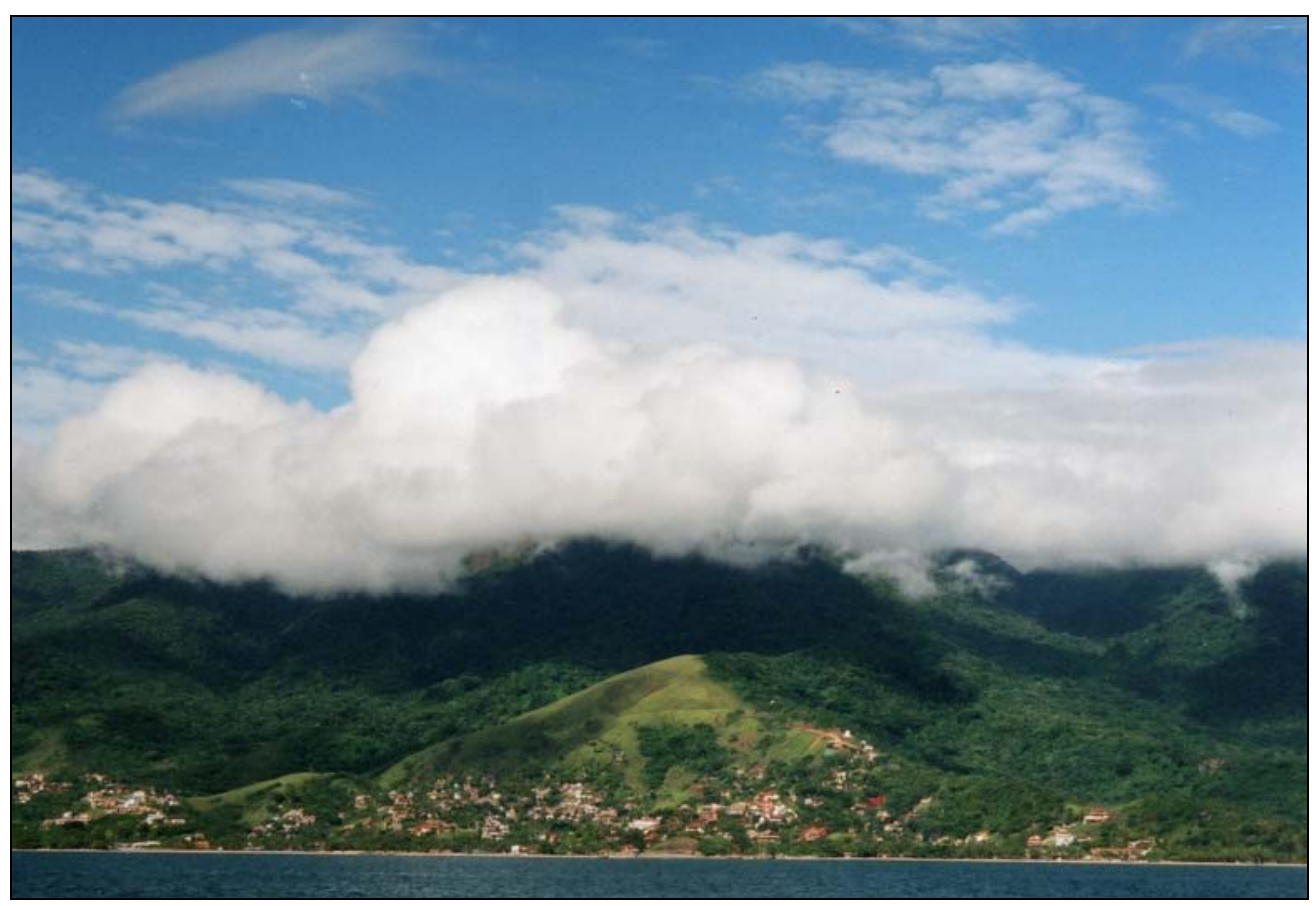

Figura 19 - Imagem da vertente continental da llha de São Sebastião, vista a partir da balsa. Possível observação da frente de brisa. $(01 / 01 / 05,16 \mathrm{~h})$

Org.: M. A. Milanesi (2005). 


\subsection{Pluviometria local}

A análise da pluviometria local só é possível para a vertente continental, na porção centro sul da ilha. Acrescidos do posto Usina Água Branca (200 m), agora, os três postos da ilha, no período de seu funcionamento (Água Branca possui apenas 17 anos de funcionamento, Burrifas com 23 anos e Ilhabela, 57 anos) firmam média climatológica anual de 1676,1 mm de chuva, para o município.

Na Figura 20, a média climatológica dos totais anuais de chuva para o posto Usina Água Branca, a $250 \mathrm{~m}$ apresenta os maiores valores (1838 mm/ano), Burrifas com 1680,8mm/ano é intermediário e, com menor quantidade de chuva média acumulada está o posto Ilhabela $(1509,6 \mathrm{~mm} / \mathrm{ano})$. Isso significa que em Burrifas chove $8,6 \%$ a menos que no posto Água Branca. O posto Ilhabela apresenta totais médios $10 \%$ inferiores a Burrifas. O posto pluviométrico Usina Água Branca apresenta quantidades de chuva em torno de $18 \%$ superiores ao posto Ilhabela.

As quantidades máximas mensais de chuvas observados nesses postos foram, Ilhabela, com 621,6 mm em janeiro de 1996, no posto Usina Água Branca, com 709,4 mm em fevereiro de 1959 e posto Burrifas, com 714 mm em março de 1983. 


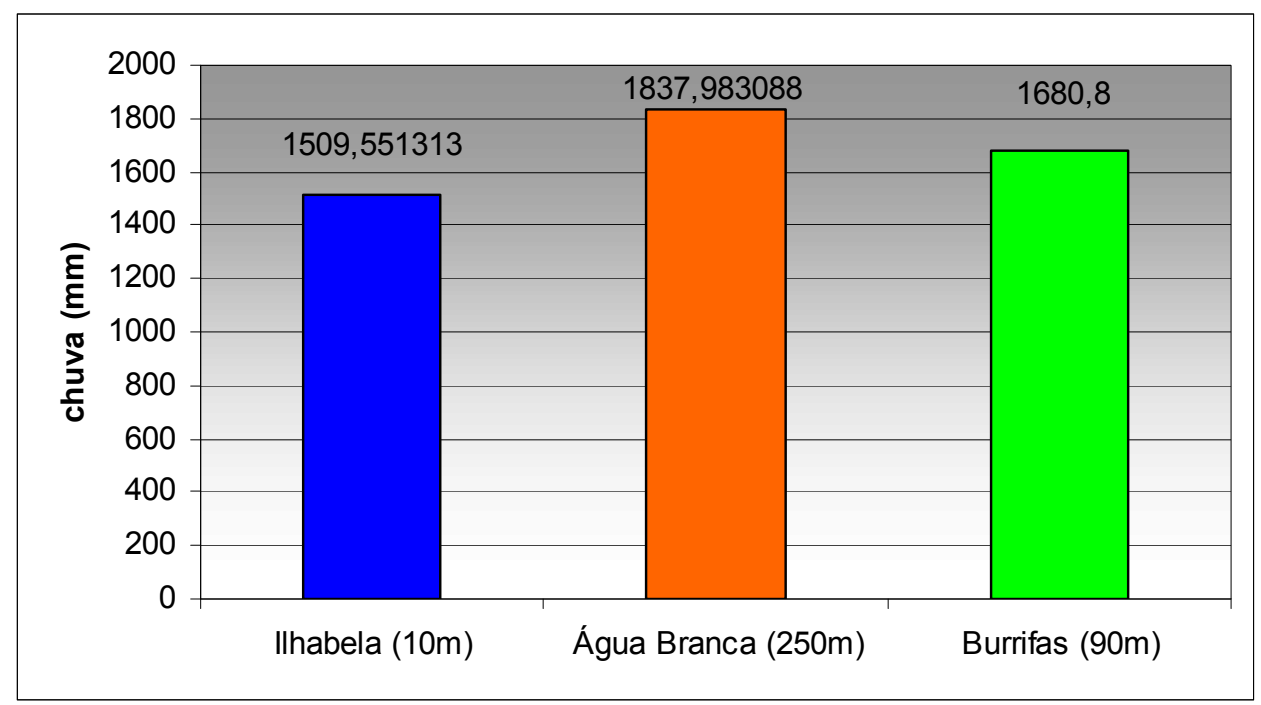

Figura 20 - Média climatológica dos totais anuais de chuva nos postos pluviométricos do DAEE na llha de São Sebastião.

Org.: M. A. Milanesi (2006).

Espacialmente, tanto médias anuais como as máximas mensais refletem a situação geográfica do sítio o qual os postos estão inseridos. Descartando as correntes de ar geradoras de chuva, o relevo age com influência notada, resultando na distribuição das quantidades observadas.

A média climatológica mensal da precipitação, na Figura 21, demonstra a influência da altitude e da situação geográfica de cada posto nas quantidades observadas e aponta para a existência de uma tendência pluviométrica na distribuição local da chuva.

O posto llhabela, a norte, além de apresentar totais anuais médios de chuva menores, também não apresenta médias climatológicas mensais superiores aos outros dois postos. No período de primavera-verão seus valores equiparam-se aos do posto Burrifas. No outono-inverno, os valores de chuva são sempre inferiores aos de Burrifas e Água Branca.

O posto Burrifas, a sul, apresenta valores de chuva ligeiramente superiores aos do posto Ilhabela na primavera-verão, com exceção de dezembro e valores 
inferiores aos do Água Branca. No período de outono-inverno, a superioridade sobre o posto Ilhabela fica mais perceptível. Entretanto, seus valores para o período, equiparam-se aos valores do posto Água Branca e até mesmo o superam na maior parte dos meses.

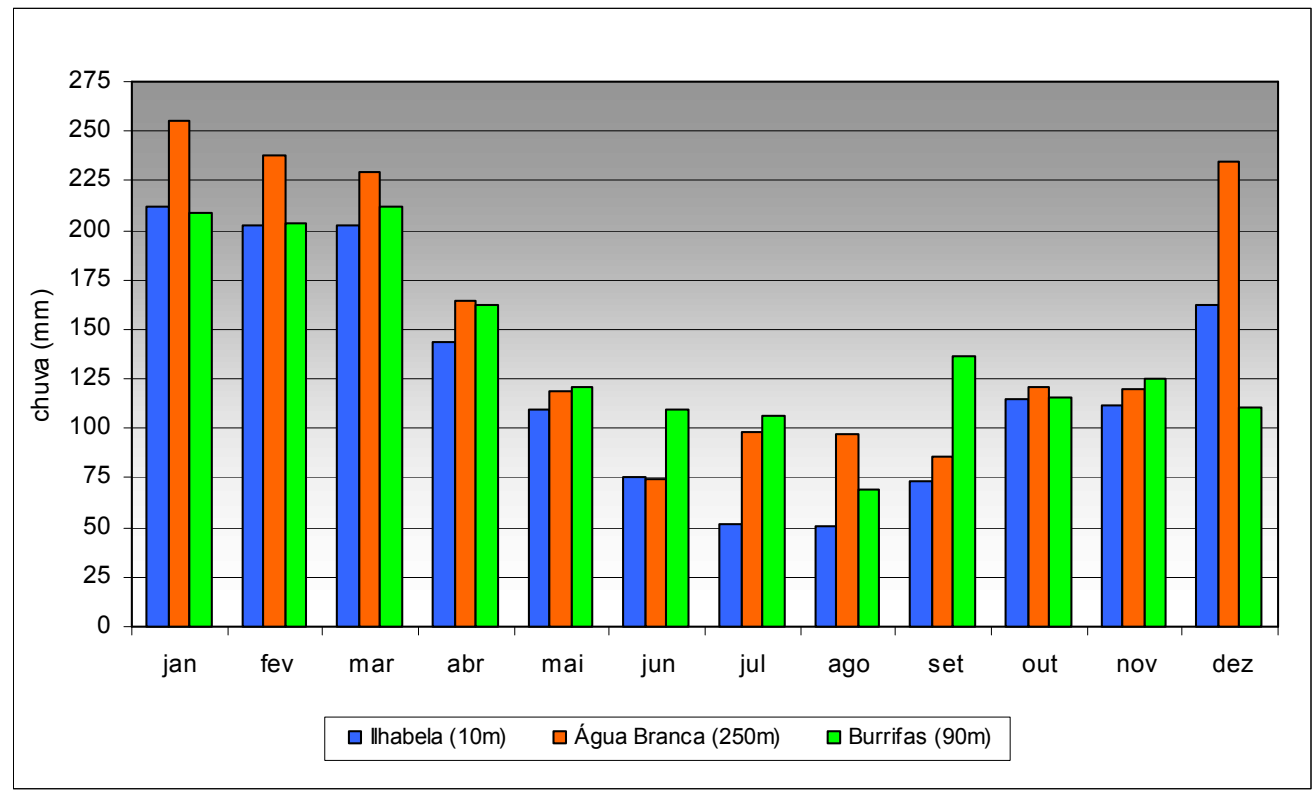

Figura 21 - Média climatológica mensal da precipitação para os postos do DAEE Ilhabela, Usina Água Branca e Burrifas.

Fonte: DAEE (2006).

O posto Usina Água Branca, no centro da ilha e em maior altitude supera os outros postos no total acumulado de chuva, porém sua distribuição temporal mostra um certo jogo com Burrifas, haja vista que Ilhabela quase sempre apresenta valores inferiores. No período da primavera-verão, Água Branca apresenta valores invariavelmente superiores a Burrifas. Já na estação oposta, é o posto Burrifas que suplanta o Água Branca, com exceção de agosto.

O que se percebe a sotavento da Ilha de São Sebastião, por meio da análise desses três postos é a diminuição da chuva no sentido sul-norte e o incremento desta com a altitude. No período da primavera-verão as chuvas são bem distribuídas entre todos os postos. O contrário acontece no outono-inverno, quando as chuvas 
concentram-se no setor sul da ilha. Em mais da metade do ano, o posto de maior altitude obteve as maiores quantidades de chuva.

Nos três casos, o relevo exerce influência preponderante. Mas, quanto à concentração das chuvas no sul, no inverno, isso pode ter sido realçado pela quantidade de frentes que se deslocam passando sobre a área de estudo pelo setor sul.

A figura 22 registra o momento de entrada de uma frente geradora de chuva pela ponta sul do canal. Nota-se o trecho sul da ilha completamente encoberto pela nebulosidade estratiforme de origem frontal, enquanto a porção norte apresenta aspecto caótico da nebulosidade, uma marca da indefinição do sistema atuante.

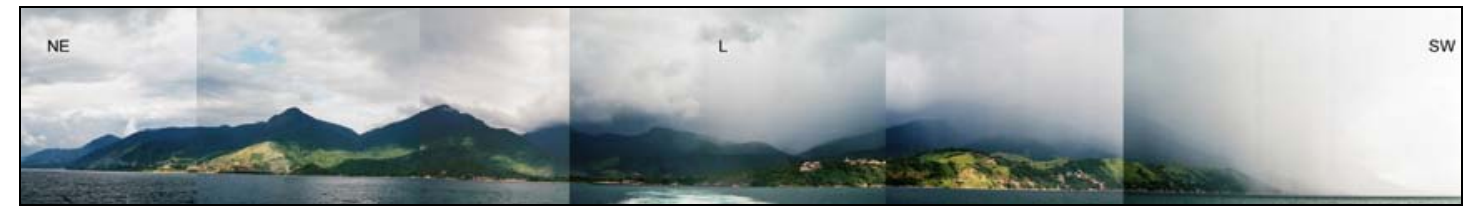

Figura 22 - Fotomontagem da vertente continental da llha de São Sebastião, vista a partir da balsa, com chuva no setor sul. $(02 / 02 / 05,17 \mathrm{~h})$

Org.: M. A. Milanesi (2005). 


\section{Hipótese de trabalho}

A partir dos pressupostos teóricos a serem mais claramente estabelecidos a posteriori, o aumento dos volumes de chuva com a altitude, postulado por Bergeron (1968), baseados no binômio relevo (orientação de vertentes e altitude) versus escoamento do ar, pretendemos quantificar e validar a afirmação da existência de um fenômeno atmosférico de ordem local, a chuva orográfica, a barlavento da llha de São Sebastião.

França (1951), já identificava a diferença pluviométrica entre as faces oceânica e continental da llha de São Sebastião devido às altitudes de seu relevo em estudo de Geografia Humana sobre a llha de São Sebastião.

Conti (1975), em seu clássico trabalho sobre a circulação secundária e efeito orográfico na gênese das chuvas na região lesnordeste paulista, investigou os principais mecanismos genéticos da precipitação, por meio do método da análise rítmica do Litoral Norte, Serra do Mar, no Vale do Paraíba e da Serra da Mantiqueira, demonstrando o predomínio dos sistemas extratropicais (fluxos polares) e a importância da atividade frontal na gênese de chuvas regionais. Propõe o autor que o relevo não mantém em sua altimetria, a principal relação com a precipitação, apenas em conjunto com a exposição de vertentes, interferindo na distribuição da pluviosidade pelo espaço, confirmando a existência das chuvas de relevo e da sombra de chuva.

Ao discutir sobre a influência da llha de São Sebastião sobre a chuva, Conti (op. cit.) aponta para o declínio das quantidades na vertente oeste e em sentido ao município de Caraguatatuba (Juqueriquerê), caracterizando a sombra de chuva. 
Quanto à chuva orográfica, lembra que somente observações na vertente exterior da ilha poderiam dar uma medida do contraste entre ambos os lados.

A reduzida malha de postos pluviométricos da ilha, apenas dois em funcionamento e um terceiro desativado com 17 anos de observações, dispõem de dados apenas para a vertente continental e a inexistência de dados sistematizados de chuvas referentes à vertente oceânica da ilha, impossibilitam a confirmação do fenômeno em escala local. Logo, a produção cartográfica referente aos atributos climáticos da Ilha de São Sebastião e, em especial, a distribuição espacial da chuva não é considerada expressão da realidade climática local, senão teoricamente.

Assim, destacamos as hipóteses norteadoras desta pesquisa: para a existência dessa sombra de chuva, é necessário um fluxo de ar úmido predominante que possibilite a nebulosidade e a chuva a barlavento da llha de São Sebastião, o que caracterizaria a chuva orográfica. E, acerca da chuva orográfica, em termos de quantidade, se é reconhecido o aumento da chuva até determinada altitude, permitindo elevadas quantidades a barlavento dos escudos da Serra do Mar, por analogia, esperamos que também sejam observadas chuvas vultuosas a barlavento da ilha, nas vertentes oceânicas, extraindo da atmosfera quantidades consideráveis de sua umidade, o que caracterizaria a sombra de chuva a sotavento da área. 


\section{Objetivos}

O questionamento mais amplo desta pesquisa baseia-se na investigação da relação "pluviosidade x orografia", ou seja, avaliar a dinâmica da chuva sob o controle do relevo, na llha de São Sebastião.

$\checkmark$ Desenvolver um pluviômetro experimental para a coleta da precipitação in loco, em diferentes unidades geomorfológicas, em diferentes altitudes;

$\checkmark \quad$ Verificar a participação dos aspectos geográficos no entorno dos pluviômetros na coleta da chuva;

$\checkmark \quad$ Evidenciar da existência de efeitos causados pelo relevo como as chuvas orográficas e a sombra de chuva;

$\checkmark \quad$ Entender o grau de influência da ilha na distribuição espaço-temporal da chuva local;

$\checkmark$ Desvendar a resposta da relação chuva versus relevo, na atuação dos principais tipos de tempo e na ocorrência de eventos extremos;

$\checkmark \quad E$, finalmente, não esgotando o tema, tentar identificar a existência de uma gênese para a chuva orográfica local ou a existência de uma constante nebulosidade local. 


\section{Referencial Teórico e Metodológico}

\subsection{Tempo e Clima}

As principais teorias do clima que orientam este estudo são aquelas propostas por Sorre e Monteiro, que propõem um caráter dinâmico à Climatologia, em contraposição às definições clássicas de Hann e Köppen, que consideram o clima como o estado médio da atmosfera. Conti (2001), retoma a questão do método afirmando que a Climatologia Geográfica não invalida os procedimentos clássicos, como a quantificação e a análise estatística, desde que sejam adequados à investigação.

Sorre (1951, apud Megale, 1984) define clima como "a série de estados da atmosfera em sua sucessão habitual", ou o retorno freqüente de determinados tipos de tempo em uma localidade, enfatizando o uso de uma "visão" mais ampla da noção de clima, que considere em seu dinamismo as leis da Meteorologia Dinâmica, responsáveis pela circulação atmosférica e suas relações intrínsecas com o lugar onde acontecem; empresta de Pédélaborde a definição dos estados da atmosfera como uma combinação original e efêmera de propriedades dos atributos do clima, expressas por meio das variações da radiação solar, temperatura, pressão, ventos, umidade e chuva, entre outros, que levou à noção de tipos de tempo ou quando uma dessas combinações se repete com freqüência.

Sorre (1951) evidencia a fundamental importância dos controles geográficos do local (latitude, altitude, exposição de vertentes, declividade, proximidade de corpos 
d'água, vegetação, uso e ocupação do solo em interação com circulação secundária da atmosfera), na idéia de diferenciação da daqueles tipos de tempo, dado o controle climático que exercem sobre os atributos do clima na troposfera.

Ainda Sorre, em 1951, estabelece que um estudo da variabilidade acerca dos tipos de tempo de cada lugar considere individualmente sua freqüência, duração e retorno, em outras palavras, a identificação da amplitude temporal de sua atuação, que origina a definição de ritmo, já que pode expressar sinteticamente as variações do clima.

Essa combinação única de "lugar x sucessão de tipos de tempo", não é finita, dado o estado caótico da atmosfera, no qual a probabilidade de existirem repetições idênticas de um tipo de tempo é ínfima. Porém, esses tipos de tempo, tendem a se repetir de forma agrupada e semelhante, com o passar do tempo cronológico, o que possibilita, estatisticamente, sua previsão.

Monteiro elabora e difunde o método da análise rítmica em climatologia por toda a sua obra, especialmente em Análise Rítmica em Climatologia. Problemas de atualidade climática e achegas para um programa de trabalho, de 1971, em que tal metodologia é exposta e discutida. A análise qualitativa é sua grande contribuição na caracterização do ritmo climático, pois considera os mecanismos da circulação atmosférica e suas dinâmicas regionais.

Monteiro (1969, p. 13), em observação à sucessão dos estados da atmosfera, propõe ser este o momento em que a abordagem climatológica atinge o nível geográfico:

"...é pela sucessão que se percebe as diferentes combinações dos elementos climáticos entre si e suas relações com os demais elementos do quadro geográfico. É a seqüência que conduz a o ritmo, e o ritmo é a essência da análise dinâmica". 
Monteiro (1971, p. 09), propõe que a observação climatológica seja feita em sua seqüência contínua para a análise dos tipos de tempo, independentemente do período cronológico de análise. Esta continuidade legitima a noção de sucessão, pois somente o desenrolar dos estados atmosféricos pode revelar o tipo em suas gradações e facetas:

“...o ritmo climático só pode ser compreendido através da
representação concomitante dos elementos fundamentais do clima em
unidade de tempo cronológico pelo menos diárias, compatíveis com a
representação da circulação atmosférica regional geradora dos
estados atmosféricos...”.

Dessa forma, a decomposição cronológica diária faz-se necessária, pois a sucessão dos estados atmosféricos ocorre em unidades menores (horas e minutos), “...apenas a partir da escala diária é possível associar à variação dos elementos do clima, os tipos de tempo que se sucedem segundo mecanismos de circulação regional". (p. 09).

Quanto às técnicas de análise utilizadas no tratamento dos dados, nota-se que a análise qualitativa esta indissoluvelmente ligada à análise estatística (quantitativa) tradicional, ou seja, enquanto esta última detém-se no tratamento de períodos históricos de observação e mensuração dos fenômenos meteorológicos, cuidando das variações dos atributos climáticos no espaço geográfico, incorrendo em generalizações, aquela trata das variações individuais em cada ponto de amostragem no tempo cronológico. De qualquer forma, essa individualidade deve refletir um parentesco através do ritmo de variação destes fenômenos em tempo real, que está indissoluvelmente ligada à individualização climática regional.

Valida, então, a noção de ritmo, sendo “...as variações anuais percebidas através das variações mensais dos elementos climáticos..." e regime, como "a repetição dessas variações mensais em vários e sucessivos anos”, admitindo que o ritmo climático e que a compreensão do regime só possa ser apreendido em, ao 
menos, 30 anos de observações, como sugere a OMM (Organização Meteorológica Mundial).

Considera que a escala regional é a mais apropriada para a expressão do ritmo climático, pois é aí que os mecanismos da circulação atmosférica transformam-se em sistemas, sob a influência da continentalidade:

"Dentro de regiões climáticas diversificam-se climas locais, os quais, à medida que decrescem em ordem de grandeza espacial, estão comprometidos pela influência direta dos fatores geográficos que agem introduzindo modificações quantitativas nos elementos climáticos". (Monteiro, 197, p. 12).

Para uma pesquisa que deseja identificar o comportamento pluviométrico de uma determinada área como a Ilha de São Sebastião, é de importância capital a decisão pela escolha da escala de análise do fenômeno.

Segundo o procedimento da análise rítmica, transitaremos entre a escala regional, pois visa, de forma geral, o entendimento da dinâmica atmosférica das massas de ar sobre a área de estudo e adjacências, e a escala local a qual se referem os dados de campo.

Definimos as escalas do clima utilizadas segundo a concepção sorreana, de 1951.

Clima regional: expressa uma associação de climas locais, uma síntese da ação dos controles climáticos como a latitude, relevo, a maritimidade e a vegetação. É esta generalização que mais se aproxima da realidade regional, quando a dinâmica atmosférica é mais simples e, a variação do relevo, mais uniforme.

Clima local: é a expressão das condições atmosféricas predominantes no entorno da estação meteorológica. É aquele que se pode definir por meio da coleta de dados numéricos de seus elementos. Um conceito associado ao clima local, mais indicado para nossa escala de análise, é o de topoclima: onde os caracteres do relevo (exposição, altitude, alinhamento, forma, entre outros) geram alterações 
principalmente na quantidade de calor recebido, o que evidentemente modifica a dinâmica dos atributos climáticos e dos tipos de tempo, em conseqüência.

Cabe dizer ainda sobre a definição de clima local e tipologia dos estados da atmosfera, que os eventos extremos, afastados do habitual, não são contemplados nessa definição, porém, não sendo excluídos do conceito, dada a sua excepcionalidade, pois que também fazem parte da série temporal.

Monteiro, em 1971, postula também, a noção de regiões climáticas, onde estas não se apresentam de maneira linear, com limites fixos, mas sim, de forma teórica, podendo ser caracterizada pela existência de uma faixa de transição, gradual, onde há o contato de regiões diferenciadas.

São oportunas as considerações desses referenciais teóricos, pois são eles que dão consistência ao método adotado para a investigação do tema, ainda que não expliquem a relação entre chuva e relevo, permeiam nosso olhar sobre os fatos observados contribuindo como input da análise e da crítica.

Em 1973, Monteiro aplicou sua metodologia da análise rítmica ao Estado de São Paulo e publicou seus resultados na obra $A$ dinâmica climática das chuvas no Estado de São Paulo - estudo geográfico sob a forma de atlas, em que caracteriza os sistemas atmosféricos dominantes na América do Sul, as formas de sucessão dos tipos de tempo, a importância da atividade frontal e características sazonais e conclui classificando o estado em nove unidades climáticas sob a luz da análise qualitativa, segundo a geomorfologia e o comportamento da pluviosidade no período analisado, entre 1941 e 1957 e entre 1944 e 1961.

No cartograma final do estudo de Monteiro, nossa área de estudo surge justamente no limite teórico entre duas zonas climáticas: a tropical e a subtropical e, entre duas regiões climáticas controladas por massas equatoriais e tropicais, ao 
norte da Ilha de São Sebastião, e por massas tropicais e, polares e de latitudes médias, ao sul.

A compartimentação denominada Litoral e Planalto Atlântico Norte, faz referência regional à área de pesquisa, que se individualiza das demais por apresentar valores de chuva muito significativos se comparados às outras áreas do litoral devido à proximidade óbvia ao oceano, à existência da Mata Atlântica e, preponderantemente, às características morfológicas da Serra do Mar e à sujeição das muitas incursões dos sistemas frontais durante o ano.

Tarifa (1975) explica os mecanismos atmosféricos por meio dos quais ocorrem os diferentes graus de intensidade das chuvas de primavera e verão no Estado de São Paulo. Utiliza-se da quantificação dos centros isobáricos de ação para caracterização de quatro formas possíveis de atuação dos fluxos polares. Classifica os fluxos polares em Dominante (com atuação MPA e frentes) quando a pressão atmosférica mantém-se acima de $1021 \mathrm{mb}$ (milibares) acentuando o controle extratropical; entre 1020 e 1016 mb, o fluxo polar é Indireto (com atuação da MTA, MTC e frentes); entre 1014 e 1010 mb, este fluxo é Oscilante, possibilitando um maior equilíbrio entre os sistemas (ação da MTC, INW) e, abaixo de 1009 mb o fluxo polar é Nulo (com atuação predominante da MTA e MTC), de controle totalmente intertropical. Considera que os limites entre as categorias são teóricos.

Os resultados de Tarifa (1975) atribuem às correntes perturbadas de sul, mas principalmente, para as atuações da FPA a geração de $67 \%$ das chuvas. Em segundo lugar, as Calhas Induzidas e FPR são responsáveis por $17 \%$ do total precipitado. As Instabilidades de Noroeste respondem por $10 \%$. Os $6 \%$ restantes da chuva são produzidos pelas atuações da MPA e MTC. Conclui que as atuações dos 
fluxos polar Dominante e Nulo individualmente não produzem grandes quantidades de chuvas.

\subsection{Chuva}

A precipitação faz parte de um grande circuito que a água percorre diariamente em seus diversos estados físicos. É a partir de processos físicos atmosféricos que envolvem transferência de energia (calor) que se dá a transformação da água no estado gasoso (vapor d'água) para o estado líquido (chuva, garoa) e, eventualmente, sólido (granizo) em que se descreve no ciclo da água. No Brasil, a forma mais comum de precipitação é a líquida, conhecida como chuva.

A saturação do ar, a quantidade de vapor nele existente, é que permite a formação da chuva. Esta saturação pode acontecer de duas maneiras: por resfriamento, ao se elevar sobre o relevo e, por meio do aumento do vapor d'água na atmosfera, pela evaporação, que é preponderante na área de estudo. A ascenção do ar úmido em um determinado ambiente determina que ao alcançar níveis altimétricos mais elevados atinja temperaturas mais baixas. Como a capacidade do ar de conter vapor de água varia de acordo com a temperatura, o resfriamento da massa de ar gera a diminuição de seu volume, reduzindo a capacidade do ar em mantê-la. A condensação do vapor ocorre preferencialmente sobre os núcleos higroscópicos (aerossóis, poeiras e sais, notadamente o cloreto de sódio - $\mathrm{NaCl}$ proveniente da evaporação das águas marítimas), gerando gotículas de dimensões microscópicas, ainda incapazes de vencer as forças ascendentes que as mantém 
em suspensão, formando as nuvens. Quando a gotícula se torna suficientemente grande e pesada para vencer a resistência do ar, inicia-se o processo de colisão, que aglutina novas gotículas à primeira. Assim, mais um novo processo se inicia concomitantemente à colisão, a coalescência - à medida que a gota cresce, em sua trajetória gravitacional, torna-se maior e passa a sofrer com a resistência do ar, que a divide em gotas menores, reconduzindo ao processo de coalescência (até que a chuva precipite do ar a umidade nele contida, quando esta pára).

Ayoade (1988) classifica a precipitação líquida em três tipos de chuva: a convectiva, a ciclônica e orográfica. Este último tipo é o alvo desta pesquisa.

A chuva convectiva está ligada aos movimentos verticais da atmosfera causados por aquecimento diferencial em uma certa área do terreno. É associada a nuvens do tipo cumulus e cumulonimbus. A intensidade de sua precipitação é elevada, gerando quantidades elevadas de chuva em curto período de tempo. Costuma ocorrer distribuída isoladamente nos fins de tarde do verão.

O tipo frontal é decorrente dos movimentos atmosféricos horizontais de grande escala (sinóticos) associados ao choque entre sistemas de alta e baixa pressão. Apresenta intensidade moderada e contínua de chuva, com duração de horas a dias, podendo ser generalizada por vastas áreas por onde a depressão se desloca.

Já a chuva orográfica por definição é aquela gerada por movimento vertical forçado do ar sobre uma área em elevação. Sua precipitação usualmente ocorre a barlavento de montanhas e pode se apresentar a partir de nuvens tipo cumulus, duração e quantidade muito variáveis, logo, de intensidade questionável.

Pezzopane, et al. (1995) avaliaram o dinâmica da chuva ao longo do dia no decorrer do ano em três municípios paulistas (Ribeirão Preto, Pindorama e Ubatuba), no período de 1957 a 1976, a partir de suas diferenças horárias. Aponta 
para a orografia e para os movimentos convectivos como determinantes no comportamento da chuva ao longo do dia. Seus resultados afirmam que em Ubatuba a freqüência horária da chuva apresenta as diferenças mais significativas em um ano. Nos meses de diferenças menos significantes (junho a setembro), a probabilidade de chuva acima de $5 \mathrm{~mm} / \mathrm{h}$ é menor que $5 \%$ em todos os horários do dia, com predomínio de chuva frontal. Nos meses de diferenças significativas (outubro a maio), o período da manhã é o de menor probabilidade de chuva. Em janeiro, o horário de maior probabilidade de chuvas é entre as 13 e as 3h da manhã, com intensidades máximas por volta das 17 às 19h, com predomínio de chuvas convectivas.

\subsection{Vento}

Todo deslocamento de ar sobre a superfície terrestre é denominado vento. Em escala local, em dependência dos atributos geográficos e do aquecimento diferenciado entre continente e oceano, é conhecido como brisa.

Todo vento sopra das áreas de alta pressão para as áreas de baixa pressão. 0 mecanismo formador das brisas pode ser descrito em decorrência da pressão atmosférica, ou o peso que a atmosfera exerce sobre um determinado lugar. A pressão varia conforme a temperatura ou o aquecimento de superfícies diferentes (aquecimento diferencial). Quando uma coluna de ar se aquece em relação à atmosfera adjacente, torna-se mais leve e capaz de vencer a força da gravidade da Terra, apresentando pressão mais baixa. A conseqüência desse processo é sua 
expansão e divergência em níveis superiores. Para substituir esse ar em elevação ocorre movimento lateral do ar (advecção), vento, propriamente dito. Esse não é o único mecanismo de vento conhecido, porém, dada a escala deste trabalho, não nos é pertinente sua explicação.

Em zonas costeiras, como a área de estudo, a brisa (vento local) mais perceptível é a do mar ou brisa diurna. Durante o dia, a radiação incidente sobre o continente gera um aquecimento atmosférico maior do que o sobre o oceano, logo, a existência de uma região de baixa pressão sobre o continente é evidenciada. Como resultado desse aquecimento diferencial, o movimento do ar, ocorrerá do oceano para o continente, em níveis altimétricos mais baixos, configurando a brisa do mar. À noite, o processo se inverte e o fluxo de ar será do continente para o oceano.

De forma invariável, a presença do oceano, se constitui como a maior fonte de vapor d'água nas áreas costeiras, podemos crer então que a brisa do mar tem como característica indissociável, a presença de umidade.

\subsection{Chuva Orográfica}

A teoria de Bergeron - Findensen, de 1935, descreve o processo formador da chuva orográfica, em nuvens frias (com temperatura inferior a $0^{\circ} \mathrm{C}$ ) que, geradas pela ascensão diferencial da coluna de ar (convecção), mantém simultaneamente cristais de gelo e gotículas de água em seu interior, que se vaporizam sobre os cristais, tornando-se núcleos de condensação, proporcionando um aumentando de 
volume, que ocasiona precipitação mais intensa. (Tucci e Bertoni (2000) apud Conti e Mendes (2003)).

Ayoade (1988) caracteriza chuva orográfica como a causada total ou principalmente pela ascensão do ar úmido, sobre uma área em altitude (montanhas), que sofrem resfriamento adiabático (redução da temperatura da coluna de ar em $0,6^{\circ} \mathrm{C}$ a cada $100 \mathrm{~m}$ de altitude, sem transferência de calor para o ambiente), e resulta na formação de nuvens e chuvas. O deslocamento horizontal da massa de ar úmido pode provocar o contato com uma atmosfera de menor temperatura, induzindo o processo de condensação e, conseqüentemente, de precipitação.

Para Ramos et al. (1989) apud Guerra e Cunha (1994), as chuvas de ordem local são as principais responsáveis pelas variações quantitativas sobre um determinado espaço, sobrepondo-se até mesmo às perturbações frontais. Possuem mecanismos causais conhecidos: convecção do ar por aquecimento diferencial e ascensão forçada do fluxo aerológico por barreiras orográficas.

Bergeron (1968, apud Blanco, 1999), descreve a existência de mecanismos de intensificação na gênese da chuva de relevo: autoconversão, convecção disparada e semeador-alimentador.

No mecanismo da autoconversão, a chuva é o resultado da elevação forçada da coluna de ar em grande escala pela vertente. Se a temperatura, a umidade e os ventos forem constantes, o crescimento das gotas e a coalescência deverão ser similares em qualquer ponto da montanha, provocando chuva com característica temporal uniforme. Este processo é típico em situações de fluxos de ar fracos sobre orografia de grande escala e em nosso caso, está associado à ação da brisa marinha. 


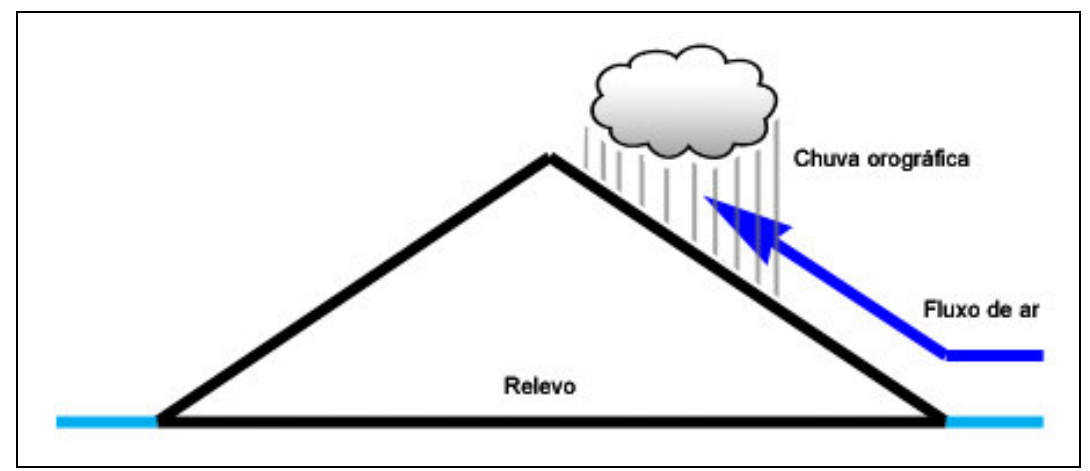

Figura 23 - Esquema teórico do mecanismo de autoconversão.

Org.: M. A. Milanesi (2007).

A chuva gerada pelo mecanismo da convecção disparada ocorre fundamentalmente pela formação de nuvens tipo cumulonimbus, de grande desenvolvimento vertical, na vertente mais ensolarada da montanha. Não apresenta uma característica marcante na distribuição vertical da chuva na encosta, porém, caso a encosta seja vegetada, pode agir como fonte de umidade em altitudes mais elevadas. Este processo é claramente uma marca do aquecimento diferencial de vertentes opostas, dada a quantidade de radiação solar absorvida ao longo do dia.

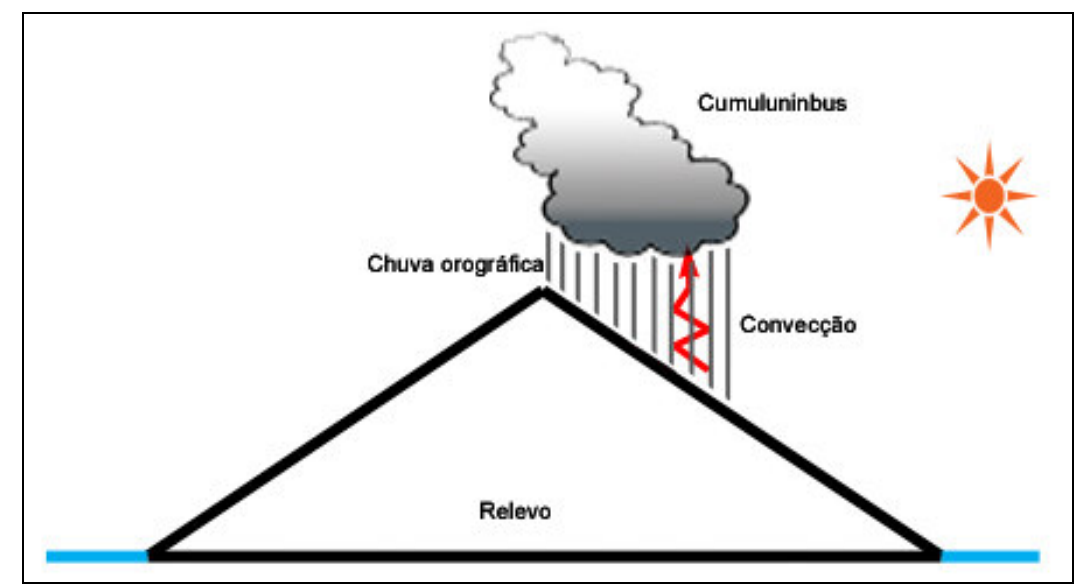

Figura 24 - Esquema teórico do mecanismo de convecção disparada.

Org.: M. A. Milanesi (2007).

O último mecanismo de intensificação orográfica é conhecido como semeadoralimentador (seeder-feeder) e pressupõe a existência de nuvens mais altas em 
processo de precipitação (seeder) sobre nuvens mais baixas (feeder) ocorrentes pela ascensão da coluna de ar sobre a vertente, aumentando a colisão entre as gotas. No modelo conceitual de Bergeron, a chuva de altos níveis umidece a camada de ar abaixo por meio da evaporação da gota em sua trajetória gravitacional. A perda de massa de água para o ambiente facilita a formação de nuvens baixas, com bases aproximadamente entre 50 e 200m acima do nível da superfície.

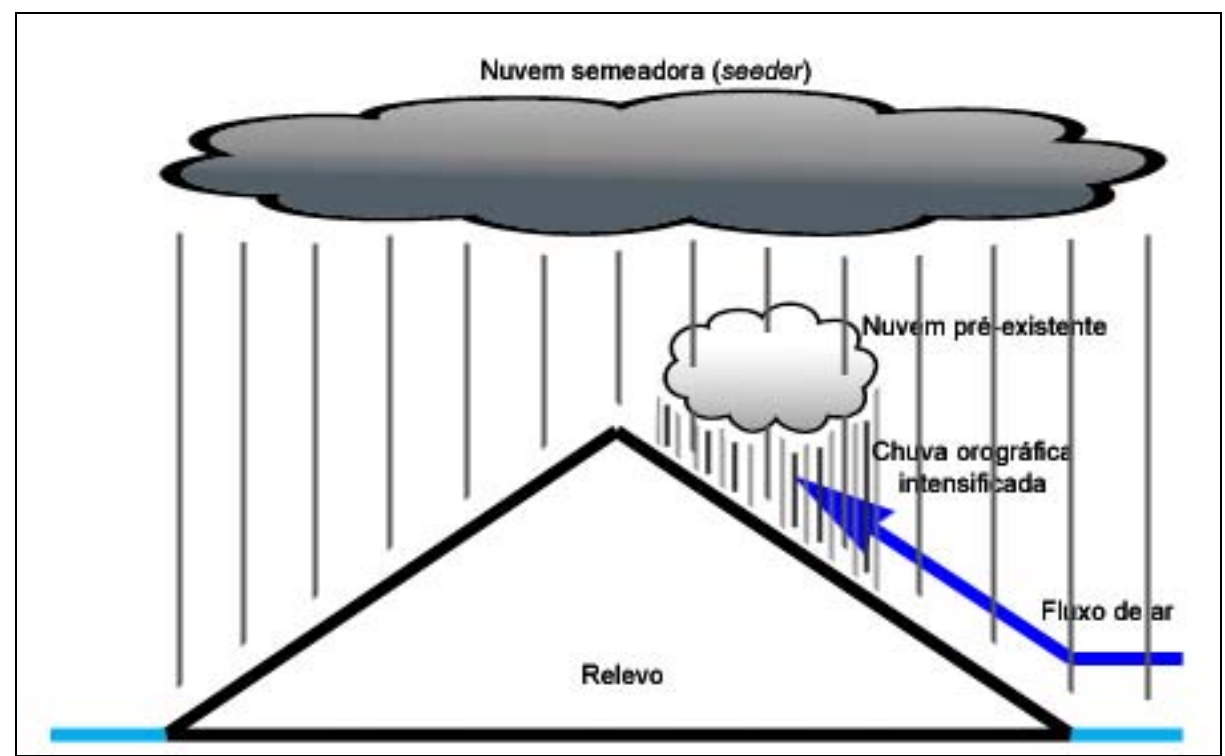

Figura 25 - Esquema teórico do mecanismo seeder-feeder, proposto por Bergeron (1968).

Org.: M. A. Milanesi (2007).

Blanco (1999) que introduz a teoria de Bergeron (1968) acerca da intensificação orográfica, atribui a Smith (1979) o decifrar dos mecanismos desse tipo de chuva. 


\subsubsection{Mecanismos da Precipitação Orográfica}

Barry e Chorley (1979) afirmam que as montanhas influenciam a chuva das seguintes formas:

a) ao retardar por atrito, uma corrente de ar que se move do oceano para o continente gerando convergência e ascensão;

b) causando convergência e elevação através do afunilamento da corrente de ar nos vales;

c) provocando instabilidades convectivas ao favorecer o deslocamento inicial (quando estável) de correntes de ar, por meio de aquecimento diferencial (vertentes diretamente expostas a maior ou menor insolação);

d) forçando a ascensão turbulenta do ar pela fricção superficial (atrito com a superfície), incorrendo na formação de nuvens stratus e stratocumulus e possível precipitação de garoa ou chuvas rápidas;

e) aumentando a precipitação de origem ciclônica e retardando seu deslocamento.

Segundo Ayoade (1988), o relevo exerce diversos graus de controle sobre a precipitação respeitando determinados limites como o seu tamanho e sua orientação relativa aos ventos úmidos e, à estabilidade atmosférica. Quando estável, o efeito orográfico é restrito aos níveis mais baixos, mais próximos às vertentes ou montanhas e influi na redistribuição da chuva. Quando instável, o efeito orográfico potencializa e redistribui o volume da precipitação por uma área maior. Afirma ainda que uma posição perpendicular do obstáculo natural à entrada das massas de ar torna-se fundamental para a geração das chuvas. 
ROE et al. (2003) dizem que o controle da distribuição da chuva orográfica está ligado à geometria da montanha ou vertente, em especial ao trinômio elevação, declive e orientação. Quanto maior a montanha, maior será sua influência sobre a chuva.

Em suma, o controle orográfico sobre a precipitação advém de inúmeros controles que variam tanto em escala espacial quanto temporal. A proximidade do obstáculo de relevo a grandes corpos d'água como o oceano é, sem dúvida, um facilitador do processo, ao disponibilizar vapor d'água necessário para sua realização. Os fatores físicos específicos à morfologia do relevo como área, comprimento, largura, altitude, declividade, orientação geral e das vertentes, profundidade dos vales aliados à cobertura do solo e rugosidade do terreno, são determinantes no processo de controle. Porém, o principal desencadeante do processo genético da chuva orográfica parece ser o fluxo de ar, representado pela atuação dos sistemas atmosféricos regionais (ventos predominantes), pela brisa marinha e pela própria instabilidade potencial da atmosfera circundante (convecção).

Não se pode dizer que a llha de São Sebastião seja comparável a um grande alinhamento montanhoso a ponto de gerar perturbações na alta atmosfera, por outro lado, também não se pode considerá-la como de pequena expressão altimétrica, pois que seus pontos mais altos estão acima dos $1000 \mathrm{~m}$, altitude superior a muitas áreas da Serra do Mar. Além de sua favorável situação geográfica, parece que os elementos morfológicos mais importantes para a ativação da chuva orográfica estão ligados ao aquecimento diferencial das vertentes (orientação e exposição à atividade solar diurna), a suas declividades e à canalização e convergência dos fluxos de brisa pelos vales (encaixados e dissecados) da vertente oceânica da ilha. 
Evidentemente, a disponibilidade de vapor d'água para a atmosfera está garantida dada a proximidade do oceano e a direção dos ventos predominantes que a transporta.

A possibilidade de todos os mecanismos ocorrerem na área de estudo é muito grande.

A circulação secundária ou a atuação dos sistemas de altas e baixas pressões marca na região a presença de ventos do setor sudeste (massas de ar vindas do oceano e de latitudes mais altas), indo de encontro aos paredões da Serra do Mar e da Ilha de São Sebastião, de alinhamento geral SW-NE. Por sua altitude e extensão, a ilha interfere, mas não necessariamente altera, as características dessas massas de ar, incrementando seu potencial de saturação e condensação.

A convergência e elevação dos fluxos de ar ocorrem no momento da transposição do relevo da ilha, quando o ar marítimo está se alterando suas características originais (resfriamento adiabático). É responsável pelo acúmulo de nebulosidade nas porções mais altas da ilha, na "Serrinha".

As instabilidades convectivas (movimentos verticais da atmosfera), causadas por aquecimento diferencial, ocorram em toda a área, pois não dependem necessariamente da existência de montanhas ou de um relevo mais proeminente, por estarem voltadas em sentido ao oceano (sudeste), recebendo um maior volume de insolação ao longo do dia, o que ativa a circulação atmosférica local (mecanismo de brisa do mar). Este fato somado às características do solo, como a umidade e a cobertura (predominantemente vegetação), denota um conjunto de características que colaboram com a intensidade da evaporação, o que também pode trazer acúmulo de nebulosidade, sob a forma de nuvens do tipo cummulus, podendo ou não provocar chuva. 
Ainda, por si só, os obstáculos naturais não chegam a remover toda a umidade presente em uma massa de ar, mesmo assim, recebem mais chuvas a barlavento do que as áreas circundantes a sotavento, o que esboça o fenômeno conhecido por "sombra de chuva".

Individualizada de sua região, não acreditamos que a ilha seja capaz de retardar o deslocamento de frentes.

\subsection{Revisão Bibliográfica}

Leopold (1949) utilizando-se de medidas locais dos gradientes de pressão de superfície, informações de sondagem atmosférica via balão, dados de estações meteorológicas e filmagem descreve o padrão das nuvens que surge da interação entre o vento predominante e as brisas nas 4 principais ilhas do Havaí (EUA), a fim de examinar as chuvas locais e prover a explicação desses padrões nos termos da interação entre o sistema de ventos sobre e ao redor de massas montanhosas. A autora demonstra que esses sistemas de nuvens são a origem da chuva e que são suficientemente freqüentes para serem importantes influencias nos microclimas locais. O tipo de interação é, a princípio, controlado pelo tamanho e altura do obstáculo de relevo. As montanhas altas podem bifurcar o vento predominante em duas correntes de fluxo ao seu redor, enquanto um relevo mais baixo permite o vento soprar por cima de sua linha de cumeeira.

Os quatro tipos de interações entre a brisa do mar e o vento predominante, são diferenciados entre si, porém a interação depende de três fatores essencialmente: 
a) largura da área: define onde o aquecimento/resfriamento vai ocorrer para causar as brisas de terra e do mar, que presumivelmente, regula o evento;

b) a altura e a forma do obstáculo de relevo em relação à camada de inversão térmica, ajuda a determinar se o vento vai passar sobre os topos ou se vai se dividir em duas correntes laterais;

c) aspectos morfológicos da área em que o regime das brisas, principalmente a marinha, se desenvolve, abrigo ou exposição aos fluxos.

O tipo Lanai ocorre numa ilha de relevo baixo, onde o vento predominante não se bifurca lateralmente, passando por cima da cumeeira e empurrando a brisa marinha de sentido oposto gerando uma alongada frente de nuvens que pode gerar um pouco de precipitação. À tarde, no verão, associadas a essa linha de nuvens, podem surgir nuvens convectivas que geram as tempestades Naulu, a oeste da cumeeira da ilha.

O segundo tipo, Maui-Kauai, também ocorre com a oposição entre o vento predominante e a brisa marinha, porém, o relevo desta ilha é composto de dois cones vulcânicos com aproximadamente 3048 m e 1024 m, o menor. O cone maior bifurca o vento predominante, fazendo com que a linha de nuvens tenha o aspecto da letra "u", a sotavento do cone maior, não produzindo chuva, talvez convectiva a oeste. $\mathrm{O}$ cone menor permite a passagem do vento. Entre os dois cones e a barlavento da ilha, a brisa marinha torna-se mais forte e habitualmente vê-se a formação de uma linha de nuvens geradoras de chuva, em torno de 400 in por ano, a $1000 \mathrm{~m}$, podendo dobrar de quantidade no verão ou em altitudes superiores. 
O terceiro e quarto tipos de interação acontecem na Grande Ilha do Havaí e também estão relacionados a relevo de cones vulcânicos, o do Mauna Loa (norte da ilha) e o do Mauna Kea (sul da ilha), respectivamente com 4145m e $4267 \mathrm{~m}$.

O tipo Kona, terceiro tipo, ocorre também com oposição entre os fluxos atmosféricos, mas é marcado pela presença de uma grande área protegida do vento predominante a sotavento do $\mathrm{M}$. Loa onde ocorre a formação de nuvens e chuva convectivas, típicas do verão. Em dias de aquecimento intenso, esse movimento convectivo pode fazer com que o desenvolvimento vertical da nuvem se estenda até o limite da camada de inversão térmica, quando o topo desta "dobra" no sentido do vento principal. Contornando o vulcão pelo lado leste, o encontro dos fluxos forma uma linha de nuvens adjacente à vertente do obstáculo.

O quarto e último tipo leva o nome do maior vulcão da área, Mauna Kea, e ao contrário do outros tipos de interação entre os fluxos atmosféricos, acontece com ventos predominantes e brisa do mar coincidentes, de mesma direção. Durante o dia a brisa reforça a intensidade do vento, a bifurcação do fluxo perde sua validade e a linha de nuvens forma-se contra a vertente a barlavento, onde a chuva orográfica é normal e dominante, até os $1200 \mathrm{~m}$. À noite, a brisa da terra (oposta ao fluxo principal) é mais forte e gera céu limpo. Entre os vulcões, também existe um istmo, uma sela, que os separa, canalizando os fluxos numa verdadeira zona de convergência, onde a linha de nuvens ganha status de fog (nevoeiro), invariavelmente tocando o solo e respondendo por elevadas quantidades de precipitação.

Os resultados de Leopold (1949) confirmam a importância da circulação local na gênese e distribuição dos fenômenos aerológicos nas ilhas havaianas e em muito 
contribuem para o entendimento deste complexo queda-de-braço das brisas frente aos ventos predominantes na ilha de São Sebastião.

Conti (1975), afirma que a região lesnordeste paulista recebe constantemente o ar marítimo de sudeste ocorrendo, portanto, um aumento da pluviosidade nos escudos da Serra do Mar e redução a sotavento. Nesse sentido coloca que quando o fluxo do ar é invertido (instabilidade de noroeste) as vertentes continentais recebem maior precipitação, diminuindo para o litoral, porém, pouco intensa; em se tratando de um fluxo de sudeste mantido por um anticiclone, as chuvas podem ser generalizadas; uma outra possibilidade é a formação de uma ruptura que separa o ar continental do marítimo, perpendicularmente à frente-fria, é a calha induzida provocadora de pancadas isoladas de chuva.

Uma análise mais minuciosa dos cartogramas de Conti (1975), onde constam as cartas de isoietas dos anos seco (1963), habitual (1964) e chuvoso (1966), indicam a existência teórica da chuva orográfica na vertente da ilha voltada para o oceano. Em 1963, ano de pluviosidade reduzida, a vertente continental apresentou entre 1001 e 1100 mm de chuva e a vertente oceânica entre 1101 e 1200mm por ano, em média. Houve pouca ou nenhuma definição do efeito orográfico entre as estações do ano. O ano habitual de 1964, além de reforçar a diferença entre a vertente continental (entre 1001 e 1200 mm) e oceânica (entre 1201 e 1300 mm), apresenta uma faixa intermediária entre elas com valores de chuva na casa dos 1001 e 1200 mm. Essa faixa intermediária supostamente está justaposta às áreas de altimetria mais elevada. Houve clara definição do efeito orográfico em todas as estações do ano. Já o ano de 1966, de pluviosidade elevada, também marcou a situação de oposição entre as vertentes. A continental apresentou-se menos úmida 
com valores entre 1201 e 1300 mm, enquanto a oceânica, entre 1301 e 1400 mm. Houve boa definição do efeito orográfico entre as estações.

Sant'Anna Neto (1990), sobre o ritmo climático na zona costeira paulista, também aponta para o Litoral Norte como área de choque entre os sistemas intertropicais e extratropicais e, conseqüentemente frontólises, dada a situação latitudinal dessa porção do Estado. Apesar de o Litoral Norte ser menos suscetível às penetrações polares, a posição e a proximidade das escarpas ao litoral acentuam os efeitos causados pela orografia. Infere sobre a sombra de chuva e sobre a chuva orográfica, localizadas tanto nas escarpas quantos nos maciços isolados, especialmente quando voltadas para o setor sul.

Nunes (1993) avalia a relação entre chuva e altimetria no estado de são Paulo, por meio dos dados de 97 estações pluviométricas, entre 1956 e 1990, com o auxílio da técnica de análise de clusters, afirmando que a explicação das grandes diferenças pluviométricas entre os diversos setores do estado não deve ser apenas altimétrica, com exceção do litoral, onde tem peso relevante. No litoral e setores serranos orientais confirma-se a correlação existente, delineando uma tendência geral. Para a autora, no litoral, abaixo dos $20 \mathrm{~m}$ de altitude, os postos que recebem influência mais direta da brisa do mar apresentam totais anuais diferenciados do que aqueles localizados abaixo dos $300 \mathrm{~m}$. Entre os 300 e $600 \mathrm{~m}$ de altitude, as quantidades de chuva variam de $1200 \mathrm{~mm}$ a $1400 \mathrm{~mm}$ ao longo do ano, de forma homogênea, principalmente no litoral central e norte. Os três postos mais altos (Barragem Edgad de Souza, 725m, Barragem das Pedras, 730m e Bairro de Antonina, 570m), no alto da Serra do Mar, nas proximidades de Cubatão, apresentam as maiores quantidades de chuva caída, acima de $4000 \mathrm{~mm}$ por ano, em média. 
Nunes (1997), avalia a variabilidade espacial e temporal da chuva para o Estado de São Paulo, considerando 104 postos por um período uniforme (19561990). As análises foram desenvolvidas com o uso de estatística convencional, multivariada e geoestatística, permeadas pela questão escalar, visto que o estudo se baseou em fenômenos cuja abrangência foi diferenciada no tempo e espaço. Os resultados marcam a grande variabilidade espacial e temporal da chuva no território paulista. A área costeira se destacou, por apresentar registros muito superiores aos do interior. A maior variabilidade ocorreu no outono e inverno, estações sensíveis à influência da ENOS em sua fase quente (EI Niño). Verificou-se igualmente influência de fenômeno quente no Atlântico Sul. O primeiro dinamizou os totais de chuva e o segundo, diminuiu.

Para Nunes (1997) as médias climatológicas da chuva de São Sebastião (1522 $\mathrm{mm}$ ) e Ilhabela $(1483,3 \mathrm{~mm})$ identificam-se em um agrupamento diferenciado dos postos adjacentes, por apresentar volumes inferiores em toda a série temporal analisada, porém, tendo comportamento correlacionável com os outros postos litorâneos de seu universo de análise. Explica o fato pela posição da Serra do Juqueriquerê, que provoca sombra de chuva, sem referência direta ao relevo da llha de São Sebastião. Ressalta que a primavera no posto llhabela registrou os volumes mais baixos de chuva entre todas as 104 séries, inferiores até mesmo aos de outras áreas tradicionalmente mais secas.

Milanesi (1997) demonstrou que os maciços rochosos do interior da ilha funcionam como uma barreira natural que altera as características do fluxo de ar predominante em sua transposição. Foi demonstrada a diferença nos valores de umidade relativa em suas duas vertentes; aquela exposta ao fluxo de ar mostrou-se mais úmida, enquanto a outra a sotavento, apresentou valores inferiores. A 
influência da ilha torna-se notável quando observados os reduzidos totais de chuva na área da cidade de São Sebastião, na análise de séries temporais homogêneas de chuva para 7 postos pluviométricos do Litoral Norte.

Os resultados, em geral, comprovam a ocorrência de apenas um dos efeitos orográficos perceptíveis em escala regional, a sombra de chuva, caracterizada no eixo dos municípios de São Sebastião, Caraguatatuba e Ilhabela, causada, em essência, pela Ilha de São Sebastião, deixando em aberto a questão da chuva orográfica.

Blanco (1999), em seu estudo sobre os processos de intensificação orográfica da precipitação na Serra do Mar, analisou dados colhidos de estações automáticas, dados do Radar da Ponte Nova, além de imagens de satélites e observações meteorológicas de superfície com o objetivo de questionar os altos valores de chuva lá recorrentes. Conclui que os eventos pós-frontais e o mecanismo seeder-feeder predominam e são responsáveis por esta intensificação naquela área.

Cândido (2007), analisa o efeito orográfico na distribuição das chuvas em uma porção do Estado de São Paulo que engloba a Região Metropolitana de Campinas, Piracicaba, Tietê, Rio Claro e Circuito das Águas, por meio dos dados pluviométricos de uma série histórica de 30 anos e rede de 89 postos fornecidos pelo Departamento de Águas e Energia Elétrica (DAEE) do Estado de São Paulo.

De acordo com o autor, o relevo denunciou ser um elemento de destaque na constituição do clima da região analisada, visto que exerce pronunciada influência sobre as chuvas, evidenciando a relação existente entre as menores altitudes e as menores quantidades de chuva. No Vale do Rio Tietê, de altitudes inferiores a 450 metros, o montante de chuvas é significativamente menor (média anual de $1226 \mathrm{~mm}$ no município de Tietê) do que na Serra da Mantiqueira (altitudes superiores a 1500 
m) com precipitação média observada superior a 1800mm/ano. A observação dos mapas confeccionados durante a pesquisa indica que o padrão de distribuição espacial das chuvas permanece praticamente o mesmo ao longo do ano, sendo que o que varia são os montantes precipitados. 


\section{Referência Procedimental}

Os procedimentos operacionais utilizados para o desenvolvimento deste trabalho foram baseados nos quatro níveis da pesquisa científica em Geografia, apresentado por Libault, em 1971.

No primeiro nível, compilatório, realizamos a pesquisa bibliográfica acerca das bases teóricas da climatologia, das teorias da precipitação e de trabalhos realizados envolvendo o tema precipitação orográfica. Também foi feito o levantamento dos dados oficiais de precipitação na área de estudo e de sua caracterização física. Investigamos a literatura referente à construção de pluviômetros, haja vista que os dados pluviométricos obtidos na área de estudo foram coletados por meio de pluviômetros experimentais. Consideramos aqui também o material cartográfico, imageamento de satélite, trabalhos de campo e documental fotográfico.

No nível correlatório, sistematizamos e homogeneizamos os dados coletados, a fim de permitir a comparação adequada entre os dados oficiais de chuva e aqueles coletados pelos pluviômetros experimentais. Foram considerados como elementos dessa sistematização, além do período histórico, ano hidrológico de 2004 - 2005 (doravante designado $\mathrm{AH}$ 04/05), um aspecto do relevo como a orientação geral, estarem os pluviômetros voltados para o continente ou para o oceano (a barlavento ou sotavento aos fluxos atmosféricos predominantes), com o objetivo de prepará-los para posterior interpretação.

Concluídas as etapas anteriores, pudemos encaminhar o trabalho no nível semântico (terceiro). Organizados os dados e confrontados com as teorias e hipóteses de trabalho, a quantificação da chuva ganhou significado considerando 
suas possíveis variáveis, sendo então passíveis de interpretação. É por meio do raciocínio geográfico que procuramos, a partir das relações de correspondência obtidas nas constatações anteriores, alcançar uma concepção maior do problema. Este nível representa a análise e a síntese do cruzamento do teórico com o empírico e nos permitiu atingir uma gama de resultados.

No último nível, o normativo, os resultados foram classificados na tentativa de transformá-los em normas que possam ser utilizadas posteriormente, isto é, num pequeno banco de dados pluviométricos, o qual, pela diversidade de sínteses cartográficas pelas quais pode ser representado, facilita a interpretação do fenômeno. E, por isso, ser referência para outros trabalhos em ambientes semelhantes. 


\section{Materiais e Métodos}

\subsection{Dados e postos institucionais}

Para a caracterização climática da área de estudo compilamos os dados da $3^{a}$ Normal Climatológica do Brasil do posto meteorológico de Ubatuba, que compreende o período entre 1961 e 1990, publicado pelo Instituto Nacional de Meteorologia (INMET), em 1992 e identificado no Quadro 1.

O posto meteorológico Ubatuba foi escolhido não por ser o mais próximo da área de estudo, mas por ser a única estação meteorológica convencional de superfície de $1^{\mathrm{a}}$ classe da região, com série histórica capaz de fornecer observações simultâneas dos principais atributos climáticos durante um longo período de tempo. É composta de vários instrumentos que indicam e registram continuamente a variação dos atributos insolação, temperatura, pressão atmosférica, umidade relativa do ar e precipitação, que são lidos e anotados por um observador em determinados horários e, posteriormente enviado ao $8^{\circ}$ DISME (Distrito Meteorológico de São Paulo) por meio de comunicação.

Quadro 1 - Posto meteorológico do INMET utilizado para a caracterização climática regional da área de estudo.

\begin{tabular}{|l|l|l|l|l|l|l|}
\hline Instituição & Número & Nome & Município & $\begin{array}{l}\text { Altitude } \\
\text { (m) }\end{array}$ & $\begin{array}{l}\text { Coordenadas } \\
\text { geográficas }\end{array}$ & $\begin{array}{l}\text { Série } \\
\text { histórica }\end{array}$ \\
\hline INMET & 83786 & Ubatuba & Ubatuba & 8 & $\begin{array}{l}\text { Lat: } 24.26^{\circ} \mathrm{S} \\
\text { Lon: } 45.06^{\circ} \mathrm{W}\end{array}$ & 1961 a 1990 \\
\hline
\end{tabular}

Os dados de insolação, nebulosidade, temperatura (máxima, mínima e média compensada), umidade relativa do ar e chuva (total mensal e $24 \mathrm{~h}$ ) foram analisados 
e transformados em gráficos. Originalmente, a média climatológica mensal é a unidade de medida utilizada nas normais. Não houve necessidade de triagem.

Os dados representativos da pressão atmosférica não puderam ser utilizados por conta da discrepância que apresentavam em seus valores, logo, a caracterização da pressão será apresentada a partir dos dados da PCD de Caraguatatuba.

Para o entendimento da climatologia regional da precipitação foram compilados os dados das séries históricas colocadas à disposição digitalmente pelo Departamento de Águas e Energia Elétrica o Estado de São Paulo (DAEE), com base no levantamento da rede de postos pluviométricos existentes na região.

Os dados do balanço hídrico climatológico do município de Ilhabela viabilizaram o conhecimento dos estoques hídricos do solo durante o ano.

O Quadro 2 elenca os cinco postos utilizados para a composição da base de dados pluviométricos regionais e indica o número de anos excluídos do universo do tratamento estatístico por apresentarem mais de $16 \%$ (dois meses) de descontinuidades. Estão localizados em três municípios do Litoral Norte, Ubatuba, Caraguatatuba e São Sebastião. Todos eles estão situados em planícies litorâneas e, à exceção dos postos Ubatuba (E2-052) e Maresias (E2-124), são diretamente influenciados pela configuração espacial do Canal de São Sebastião.

Quadro 2 - Postos pluviométricos do DAEE utilizados para a base de dados regional

\begin{tabular}{|l|l|l|l|l|l|l|}
\hline Instituição & Número & Nome & Município & $\begin{array}{l}\text { Altitude } \\
(\mathbf{m})\end{array}$ & $\begin{array}{l}\text { Coordenadas } \\
\text { geográficas }\end{array}$ & $\begin{array}{l}\text { Série } \\
\text { histórica }\end{array}$ \\
\hline DAEE & E2-045 & São Francisco & São Sebastiẫo & 20 & $\begin{array}{l}\text { Lat. } 23^{\circ} 46^{\prime} \mathrm{S} \\
\text { Lon: } 45^{\circ} 25^{\prime} \mathrm{W}\end{array}$ & $\begin{array}{l}1943 \text { a 2000 } \\
(-14)\end{array}$ \\
\hline DAEE & E2-046 & Caraguatatuba & Caraguatatuba & 20 & $\begin{array}{l}\text { Lat. } 23^{\circ} 38^{\prime} \mathrm{S} \\
\text { Lon: } 45^{\circ} 26^{\prime} \mathrm{W}\end{array}$ & $\begin{array}{l}1943 \text { a 2000 } \\
(-5)\end{array}$ \\
\hline DAEE & E2-052 & Ubatuba & Ubatuba & 1 & $\begin{array}{l}\text { Lat. } 23^{\circ} 26^{\prime} \mathrm{S} \\
\text { Lon: } 45^{\circ} 04^{\prime} \mathrm{W}\end{array}$ & $\begin{array}{l}1945 \text { a 2000 } \\
(-15)\end{array}$ \\
\hline DAEE & E2-124 & Maresias & Sẫo Sebastiẫo & 5 & $\begin{array}{l}\text { Lat. } 23^{\circ} 47^{\prime} \mathrm{S} \\
\text { Lon: } 45^{\circ} 33^{\prime} \mathrm{W}\end{array}$ & $\begin{array}{l}1970 \text { a } 1999 \\
(-3)\end{array}$ \\
\hline DAEE & E2-128 & Porto Novo & Caraguatatuba & 10 & $\begin{array}{l}\text { Lat. } 23^{\circ} 42^{\prime} \mathrm{S} \\
\text { Lon: } 45^{\circ} 27^{\prime} \mathrm{W}\end{array}$ & $\begin{array}{l}1970 \text { a 1997 } \\
(-9)\end{array}$ \\
\hline
\end{tabular}


O Quadro 3 relaciona os três postos pluviométricos existentes no município de Ilhabela utilizados para a composição da base de dados regional e local e também indica o número de anos excluídos do universo de análise. Estão localizados em diferentes altitudes da vertente continental da ilha, portanto, em situação de abrigo ao fluxo predominante. Ao sul está Burrifas a 90m de altitude, o Usina Água Branca a 250m, nas proximidades da Estrada de Castelhanos, e o posto llhabela, encontrado mais ao norte, na vila, a $10 \mathrm{~m}$ de altitude.

Os dados das séries históricas de chuva do DAEE que apresentaram anos com falha nas observações (1 ou 2 meses inconsistentes ou inexistentes) foram corrigidos com base na média climatológica mensal.

De posse do banco de dados triado, procedemos ao cálculo das médias climatológicas mensais, a principal unidade de medida e tempo utilizada neste estudo, em conformação com as Normais Climatológicas.

Quadro 3 - Postos pluviométricos do DAEE utilizados para a base de dados regional e local

\begin{tabular}{|l|l|l|l|l|l|l|}
\hline Instituição & Número & Nome & Municipio & $\begin{array}{l}\text { Altitude } \\
(\mathbf{m})\end{array}$ & $\begin{array}{l}\text { Coordenadas } \\
\text { geográficas }\end{array}$ & $\begin{array}{l}\text { Série } \\
\text { histórica }\end{array}$ \\
\hline DAEE & E2-012 & Ilhabela & Ilhabela & 10 & $\begin{array}{l}\text { Lat. } 23^{\circ} 47^{\prime} \mathrm{N} \\
\text { Long: } 45^{\circ} 21^{\prime} \mathrm{W}\end{array}$ & $\begin{array}{l}1943 \text { a } 2000 \\
(-12)\end{array}$ \\
\hline DAEE & E2-050 & $\begin{array}{l}\text { Usina Agua } \\
\text { Branca }\end{array}$ & Ilhabela & 250 & $\begin{array}{l}\text { Lat: } 23^{\circ} 49^{\prime} \mathrm{N} \\
\text { Long: } 45^{\circ} 21^{\prime} \mathrm{W}\end{array}$ & $\begin{array}{l}1958 \text { a 1975 } \\
(-1)\end{array}$ \\
\hline DAEE & E2-142 & Burrifas & Ilhabela & 90 & $\begin{array}{l}\text { Lat: } 23^{\circ} 55^{\prime} \mathrm{N} \\
\text { Long: } 45^{\circ} 27^{\prime} \mathrm{W}\end{array}$ & $\begin{array}{l}1975 \text { a } 1998 \\
(-6)\end{array}$ \\
\hline
\end{tabular}

Como referência da pesquisa e da climatologia local escolhemos a Plataforma de Coleta de Dados (PCD) do CPTEC (Centro de Previsão de Tempo e Estudos Climáticos) - INPE, Caraguatatuba (Quadro 4), por ser a estação meteorológica automática, mais próxima e mais completa da área de estudo, com monitoramento diário e horário dos atributos do clima. Esta PCD possui curta série histórica de observações, porém, por ser uma estação automática dotada de quase todos os sensores de mensuração climatológica foi considerada essencial para a observação 
do ritmo climático do $\mathrm{AH}$ 04/05. Também está situado em área de planície faceada ao canal e seus dados são atualizados digitalmente a cada 3 horas.

Os dados de radiação solar acumulada, temperatura média (das máximas, das mínimas e média climatólgica), pressão atmosférica (médias e moda), direção e velocidade do vento (médias e moda), umidade (médias e moda) e chuva (total mensal e 24h) obtidos desta PCD também passaram por tratamento estatístico de forma a sintetizar os valores diários e horários em médias e modas mensais para que se pudesse compará-los e relacioná-los com os dados coletados em trabalho de campo. Por outro lado, mantivemos a formatação original dos dados para que cumprisse com sua função original, o de permitir uma análise rítmica local para o mês de menor total de chuva (seco) e para o mês de maior total de chuva (úmido).

Quadro 4 - Plataforma de coleta de dados (PCD) meteorológicos do CPTEC/INPE referencial da pesquisa

\begin{tabular}{|l|l|l|l|l|l|l|}
\hline Instituição & Número & Nome & Município & $\begin{array}{l}\text { Altitude } \\
(\mathbf{m})\end{array}$ & $\begin{array}{l}\text { Coordenadas } \\
\text { geográficas }\end{array}$ & $\begin{array}{l}\text { Série } \\
\text { histórica }\end{array}$ \\
\hline INPE & 32521 & Caraguatatuba & Caraguatatuba & 3 & $\begin{array}{l}\text { Lat: } 23.69^{\circ} \mathrm{S} \\
\text { Lon: } 45.42^{\circ} \mathrm{W}\end{array}$ & $\begin{array}{l}2004- \\
\text { presente }\end{array}$ \\
\hline
\end{tabular}

\subsection{Pluviômetro experimental}

Para a quantificação da pluviometria local foi necessário o desenvolvimento de um pluviômetro experimental (acumulador e não registrador) de baixo custo para a coleta dos dados de chuva na Estrada de Castelhanos, que cumprisse a função do pluviômetro padrão Ville de Paris, todavia, com precisão adequada ao tipo de observação. 
Justificamos a construção dos pluviômetros com base na insuficiência da rede de postos pluviométricos oficiais (anteriormente identificados no Quadro 3) na llha de São Sebastião, o que inviabilizaria a execução da pesquisa, já que os volumes coletados não poderiam ser comparados com aqueles da vertente oposta. Também levamos em consideração a dificuldade de acesso e do trânsito de veículos "normais" na Estrada de Castelhanos.

A característica totalizadora ou acumuladora dos pluviômetros deve-se ao intervalo relativamente longo entre as coletas dos dados (as coletas foram mensais) e, portanto, necessitando de uma capacidade maior de armazenamento.

De maneira geral o projeto para construção do pluviômetro considerou: os materiais utilizados (resistência ao tempo, mobilidade e agressão ao meio ambiente), capacidade do reservatório e informações acerca da pluviometria da região, perdas por evaporação, além da facilidade de montagem e desmontagem para a quantificação dos volumes e reparos que porventura pudesse necessitar.

Os materiais escolhidos para a construção do pluviômetro foram: o PVC (para o reservatório e as tampas superior e inferior), plástico injetado (para o funil de captação), estaca de madeira (para suporte do reservatório), além de cola adesiva e abraçadeiras plásticas. A opção por componentes plásticos deu-se pela leveza do material, que facilita seu manuseio; à sua resistência a choques e a intempéries (sol, chuva, vento e maresia); pela durabilidade, com vida útil do PVC de 50 anos. Considerou-se que o material plástico é inerte no solo e reciclável.

Durante a etapa de montagem dos pluviômetros, o problema chave foi regular a capacidade do reservatório, dada a freqüência das observações (mensal). Duas considerações foram realizadas para resolução desse problema: o relevo da ilha e a 
pluviometria regional. O primeiro determinou a opção por capacidades diferentes e o segundo, a capacidade máxima de cada reservatório.

Quanto à pluviometria regional foram analisadas as séries históricas completas de precipitação (sem quaisquer exclusões) dos postos pluviométricos do DAEE utilizados nesta pesquisa. $\mathrm{O}$ objetivo foi a identificação dos meses de máxima pluviosidade e de seus volumes máximos e assim, projetá-los com uma margem de erro, onde não haveria a possibilidade, ao menos, teórica, de que os volumes a serem medidos extravasassem o reservatório.

Decidimos por pluviômetros com reservatórios de capacidades nominais máximas diferentes dada a existência da sombra de chuva a sotavento da ilha e a fim de otimizar o corte do tubo de PVC, com comprimento padrão de $3 \mathrm{~m}$. Os reservatórios apresentam comprimentos de $1 \mathrm{~m}$ e $1,5 \mathrm{~m}$, e correspondem basicamente à vertente em que foram instalados, os primeiros, num total de 6 estão localizados na face continental da estrada e os outros sete, na face oceânica (Figura 26).
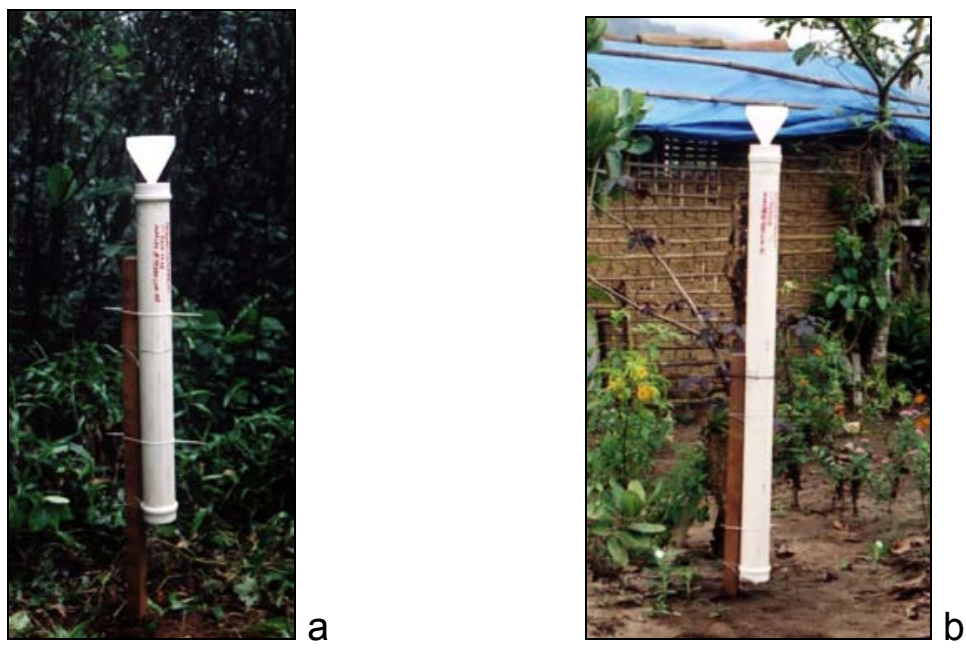

Figura 26 - Pluviômetros experimentais instalados em llhabela (à esquerda, o menor). Org.: M. A. Milanesi (2007) 
Por serem pluviômetros não registradores capazes apenas de registros totais, o sistema de medidas e coletas fez-se com o uso de três recipientes medidores (becker) com capacidades diferentes (1000ml, 250ml e 50ml) (Figura 27).

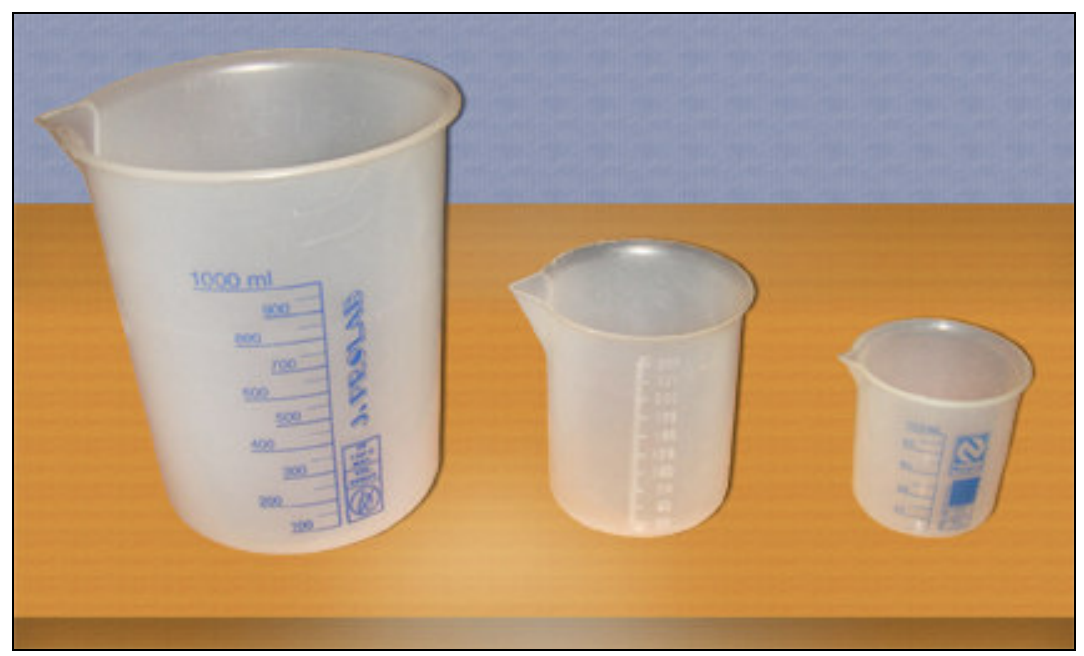

Figura 27 - Recipientes de medida (becker) utilizados para quantificação dos volumes de chuva.

Org.: M. A. Milanesi (2007).

Segundo Ayoade (1988), o volume de precipitação acumulada nos reservatórios mantém dependência com a área de captação e altura do pluviômetro (em relação ao solo), taxa de evaporação e velocidade do vento, além das características do sítio onde foi instalado.

Dadas as características muito variadas dos sítios de instalação, não foi passível a consideração quanto à velocidade do vento.

Com relação à altura dos pluviômetros, os menores foram calçados em sua base, respeitando a normalização da Organização Meteorológica Mundial (OMM) mantendo-os a $150 \mathrm{~cm}$ do solo. Já os maiores, sua dimensão, foram mantidos a aproximadamente $160 \mathrm{~cm}$.

A equação utilizada para o cálculo do volume do reservatório, haja vista seu formato cilíndrico, foi: 


$$
V=\pi R^{2} h
$$

em que,

V: volume de chuva observado,

h: nível de água,

R: raio da boca do funil (área de captação) e,

$\pi: 3,1415$

Neste caso, o volume observado, que se apresentará em mililitros (ml) precisa ser convertido em altura de chuva $(\mathrm{mm})$. Então, partindo do princípio que $1 \mathrm{~mm}$ de chuva equivale a $11 / \mathrm{m}^{2}$, o que fizemos foi utilizar a análise dimensional para transformar as unidades de medida de volume (de ml para I, dividindo-a por 1000) e de área de captação (de $\mathrm{cm}^{2}$ para $\mathrm{m}^{2}$, dividindo-a por 10000).

O raio médio dos funis é de $7,25 \mathrm{~cm}$ (os 13 funis foram aferidos com paquímetro), o que corresponde a uma área de captação aproximada de $165 \mathrm{~cm}^{2}$ e reservatórios com alturas estabelecidas de $100 \mathrm{~cm}$ e $150 \mathrm{~cm}$, portanto, as alturas máximas de chuva a serem acondicionadas são estimadas em $432 \mathrm{~mm}$ (menor) e $723 \mathrm{~mm}$ (maior).

Segundo Azevedo (2001), em estudo similar com pluviômetros experimentais, utilizando o mesmo modelo de funil, as perdas por evaporação potencial do volume de precipitação coletado são desprezíveis, dado o gargalo do funil com aproximadamente $1,2 \mathrm{~cm}$ de diâmetro.

Os dados de campo coletados com os 13 pluviômetros experimentais foram anotados em uma tabela. Dadas ações de vandalismo como furto, desmembramento de suas partes, derrube e quebra intencional, acréscimo de volumes por urina e outros líquidos e remoção não autorizada de seu sítio original, as quantidades coletadas necessitaram de triagens para sua homogeneização para que se 
pudessem compor a à análise estatística. Esta triagem adotou o critério utilizado anteriormente: a eliminação dos postos com mais de duas coletas prejudicadas (16\% do total).

No Quadro 5 são apresentados os postos pluviométricos originais instalados na Ilha de São Sebastião ao longo da Estrada de Castelhanos, sua altitude e localização. Também são identificados aqueles que apresentaram inconsistências nas coletas.

Quadro 5 - Postos pluviométricos originais instalados na Ilha de São Sebastião

\begin{tabular}{|c|c|c|c|c|}
\hline Posto & $\begin{array}{l}\text { Cota } \\
\text { (m) }\end{array}$ & Sítio de instalação & Localização & Problemas \\
\hline p1 & 3 & Planície do Perequê & particular & Removido (1x) - mantido \\
\hline p2 & 170 & vertente continental & particular & \\
\hline p3 & 300 & torre de observaçã̃o & PElb - trilha & $\begin{array}{c}\text { Quebrai adulterado (4x) - } \\
\text { eliminado }\end{array}$ \\
\hline p4 & 450 & vertente continental & PElb - estrada & $\begin{array}{c}\text { Desmontel quebra (3x) - } \\
\text { eliminado }\end{array}$ \\
\hline p5 & 600 & vertente continental & PElb - estrada & $\begin{array}{l}\text { Desmontei quebra }(2 x) \text { - } \\
\text { mantido }\end{array}$ \\
\hline p6 & 670 & divisor de águas & PElb - estrada & $\begin{array}{l}\text { Desmontel quebra }(4 x) \text { - } \\
\text { eliminado }\end{array}$ \\
\hline p7 & 600 & vertente oceânica & PElb - estrada & $\begin{array}{c}\text { Desmontel quebra }(2 x) \text { - } \\
\text { mantido }\end{array}$ \\
\hline p8 & 460 & vertente oceânica & PElb - estrada & Vandalismo' furto - eliminado \\
\hline p9 & 290 & vertente oceânica & PElb - estrada & Vandalismo (1x) - mantido \\
\hline$p 10$ & 145 & vertente oceânica & PElb - estrada & Vandalismol furto - eliminado \\
\hline p11 & 5 & Planície de Castelhanos & particular & \\
\hline p12 & 5 & Planície de Castelhanos & particular & \\
\hline p13 & 2 & Planície de Castelhanos & particular & Adulterado (1x) - mantido \\
\hline
\end{tabular}

Os postos 2, 11 e 12 não apresentaram quaisquer tipos de problemas. O posto 1 foi removido do lugar original da instalação e reinstalado a aproximadamente $70 \mathrm{~m}$ sob condições geográficas locais muito semelhantes. Porém, não foram computados na análise estatística os dados dos postos 8 e 10, com 58,3\% das observações comprometidas por furto do equipamento. Também não entraram nesta análise os postos 3, 4 e 6 por conterem mais de 16\% das observações comprometidas por vandalismo. Como conseqüência disso dos 13 postos originalmente instalados restaram 8 com boa confiabilidade de dados.

Em especial, os dados dos postos 11, 12 e 13 foram transformados, a partir de sua média, em uma só série. Localizados na porção norte (p11), na porção central 
(p12) e na porção sul (p13) da Praia de Castelhanos (de face SE, com aproximadamente $2 \mathrm{~km}$ de extensão), apresentaram durante o período dos trabalhos de campo uma homogeneidade e qualidade muito elevada com relação aos dados lá obtidos.

Desta forma, os dados oficiais de chuva deste estudo compõem-se daqueles obtidos dos 6 postos pluviométricos restantes. Assim, mantivemos as nomenclaturas originais dos postos, 1, 2, 5,7 e 9. Já os postos 11, 12 e 13 tornaram-se p12, por meio de sua média.

O Quadro 6 apresenta os "novos" postos pluviométricos, efetivamente utilizados no estudo. Podemos notar ainda, a especialidade de sua localização, a sua posição diferenciada no contexto geomorfológico da ilha, contemplando planície, meia vertente e vertente alta, próxima do divisor de águas.

Quadro 6 - Postos pluviométricos oficiais desta pesquisa

\begin{tabular}{|l|l|l|l|}
\hline Posto & Cota (m) & Sítio de instalaçäo & Localizaçảo \\
\hline 11 & 3 & Planície do Perequê & particular \\
\hline p2 & 170 & vertente continental & particular \\
\hline$p 5$ & 600 & vertente continental & PElb - estrada \\
\hline$p 7$ & 600 & vertente oceânica & PElb - estrada \\
\hline$p 9$ & 290 & vertente oceânica & PElb - estrada \\
\hline p12 & 5 & Planície de Castelhanos & particular \\
\hline
\end{tabular}

Na busca pela homogeneização dos dados, procedemos ao preenchimento das falhas dos postos que tiveram problemas em até dois meses, com base na média entre os valores do posto anterior e posterior.

O banco de dados pluviométrico estabelecido com os trabalhos de campo recebeu tratamento gráfico e estatístico dos dados, visando definir um ritmo da precipitação de ocorrência, sazonalidade, a influência orográfica e sua decorrente espacialização (altitudinal), para a confecção de cartogramas na busca de seu perfil pluviométrico. 
Precedida da análise quantitativa, a análise rítmica para caracterização da gênese dos tipos de tempo produtores de chuva no AH 04/05 restringiu-se à quantificação das observações da dinâmica geral da pressão atmosférica da PCD de Caraguatatuba, segundo Tarifa (1975), para a identificação do grau de intensidade dos fluxos polares durante o ano. Ocorreu paralelamente à consulta da Revista Climanálise, do CPTEC/INPE.

Ao contrário de Tarifa (1975) estabelecemos limites estáticos para as situações de indefinição entre os diversos fluxos, a saber: $1021 \mathrm{mb}$ para indefinição entre o fluxo polar Direto e o Indireto; 1015mb para a indefinição entre o fluxo Indireto e o Oscilante e, 1009mb entre o Oscilante e o fluxo polar Nulo.

Porém, por ser uma constatação estatística, sem o balizamento da análise em escala sinótica, não pudemos determinar precisamente os tipos de tempo que originaram as chuvas observadas.

O banco de dados pluviométrico recebeu tratamento estatístico tradicional, em busca de sua temporalidade e espacialidade. Foi sucedido pela análise das informações com outros postos da área, que permitiu uma série de relacionamentos entre a pluviosidade e o relevo, até alcançarmos sua correlação linear, que resultou numa equação que descreve o gradiente pluviométrico local em função das altitudes.

O cruzamento das informações dos três modelos da intensificação da chuva orográfica de Bergeron (1968) com os quatro padrões de interação entre a brisa e o vento predominante propostos por Leopold (1949), forneceram bases para o entendimento da distribuição da nebulosidade no barlavento da ilha brasileira, quando procedeu-se à construção gráfica de um modelo teórico longitudinal para o 
descrevendo uma situação atmosférica ideal. Este modelo corrobora a teoria da chuva orográfica.

A síntese final deste trabalho também é a construção de modelo que se baseia em Bergeron e Leopold, porém, agora relacionados e aplicados à distribuição espacial da chuva na Ilha de São Sebastião observada no AH 04/05.

\subsection{Trabalhos de campo}

Foram realizados ao todo 14 trabalhos de campo, sendo 2 para montagem e desmontagem do equipamento e 12 para a verificação dos volumes coletados, em todo o dia primeiro de cada mês. O período de coleta compreendeu o ano hidrológico de 2004 e 2005 (AH 04/05), que se iniciou em $1^{\circ}$ de outubro de 2004 e findou em 30 de setembro de 2005.

A escolha pelo ano hidrológico se deu por contemplar o período de "reaquecimento" do hemisfério sul com a chegada da primavera, em que há a intensificação cíclica dos processos globais que comandam o retorno da estação chuvosa, que marca o regime climático regional.

O acompanhamento diário dos boletins meteorológicos especializados foi necessário, pois os eventos extremos de chuva, aqueles que escapam ou não são considerados como habituais, normalmente não são previstos, onde então o trabalho de campo se faria a cada 15 dias, ou na medida em que fossem necessários.

A instalação do equipamento aconteceu em 30 de setembro de 2004 permitindo as coletas de chuva já em outubro. Promoveu ainda, a troca entre o conhecimento 
local e o acadêmico, como melhor forma de reconhecer neste espaço, os sítios mais adequados para a instalação dos equipamentos, pois deles dependem quantidades milimétricas importantíssimas de chuva. Contamos com as sugestões de Seu João nosso motorista e funcionário do PElb, conhecedor da estrada há mais de vinte anos, que nos auxiliou na decisão dos melhores sítios para a instalação dos pluviômetros, haja vista que nem todos os postos puderam ser instalados nas margens da estrada. Por outro lado, tentamos encontrar bons sítios no ambiente da mata que não apresentassem um dossel fechado. Os postos instalados em terrenos particulares não possuíam obstáculos naturais à coleta da chuva.

Considerou-se concomitantemente, de forma teórica, a técnica do sky view factor, que pressupõe uma avaliação do nível de obstruções às quais a área de captação do pluviômetro está sujeita.

Durante a etapa da escolha do sítio e instalação dos pluviômetros, procuramos seguir as considerações do DAEE que determina em suas "Recomendações para a instalação de um posto pluviométrico" o uso do procedimento padrão da OMM, para garantia de máxima confiabilidade em ambientes urbanos, derivada por nós para o ambiente natural.

O cumprimento das mais de 15 considerações da OMM para a instalação dos pluviômetros não pode ser contemplada dada a quantidade de restrições que o Sistema Nacional de Unidades de Conservação (SINUC) propõe para suas unidades.

A Figura 28 registra o momento de desmonte do equipamento para a coleta da medida de chuva. Durante os trabalhos de campo fomos assessorados pelo auxiliar de pesquisa do PElb, Marcos Aurélio (em pé), sem o qual, nossos esforços teriam de ser redobrados para a realização das rotinas desta tarefa. 


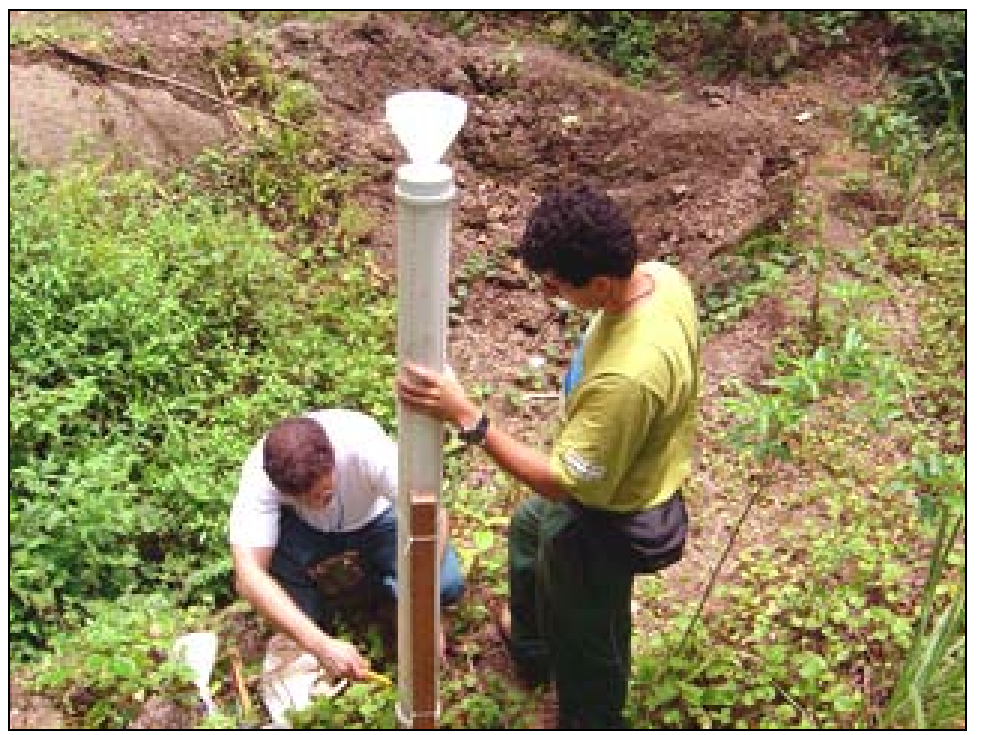

Figura 28 - Trabalho de desmontagem do pluviômetro experimental para medição da chuva. Autor: Carlos Senger (2006) 


\subsection{Material cartográfico}

Para a execução deste estudo utilizamos os seguintes materiais cartográficos:

a) carta topográfica São Sebastião na escala 1:50.000 folha SF-23-Y-D-VI-

3. Esta contém $80 \%$ da llha de São Sebastião, incluindo a totalidade da Estrada de Castelhanos, de onde foi extraído o perfil topográfico, para avaliação da altimetria e declividade local, além de localizar os postos pluviométricos, carta hipsométrica, para avaliação do modelado do relevo nas adjacências da estrada, incluindo os dois pontos mais elevados da ilha e contorno da ilha para confecção de modelagem teórica acerca da brisa do mar, do fluxo de ar predominante e das áreas das vertentes onde se verificou acumulo de nuvens e chuva,

b) Imagem do satélite CBERS2 CCD, de 20 de março de 2006, que registra a ocorrência do alinhamento da nebulosidade com o relevo, característica do controle da orografia sobre a circulação do ar.

c) Imagem do satélite Landsat-5 TM, composição colorida: bandas 3/4/5 de 20 de agosto de 1988. Fornece uma idéia da ocupação do solo. 


\section{Resultados e discussão}

A análise rítmica mensal da PCD de Caraguatatuba traça um quadro da dinâmica climática do $\mathrm{AH}$ 04/05, numa tentativa de aplicação da técnica de Monteiro, 1973.

\subsection{Radiação Solar}

A variação da radiação solar acumulada foi obtida por meio da média climatológica diária dos valores observados, está de acordo com o diagrama de Sellers (1965, apud Varejão e Silva, 2006), para as áreas tropicais como demonstra a Figura 29, com média mensal de $448 \mathrm{kcal} / \mathrm{cm}^{2} . \mathrm{min}$.

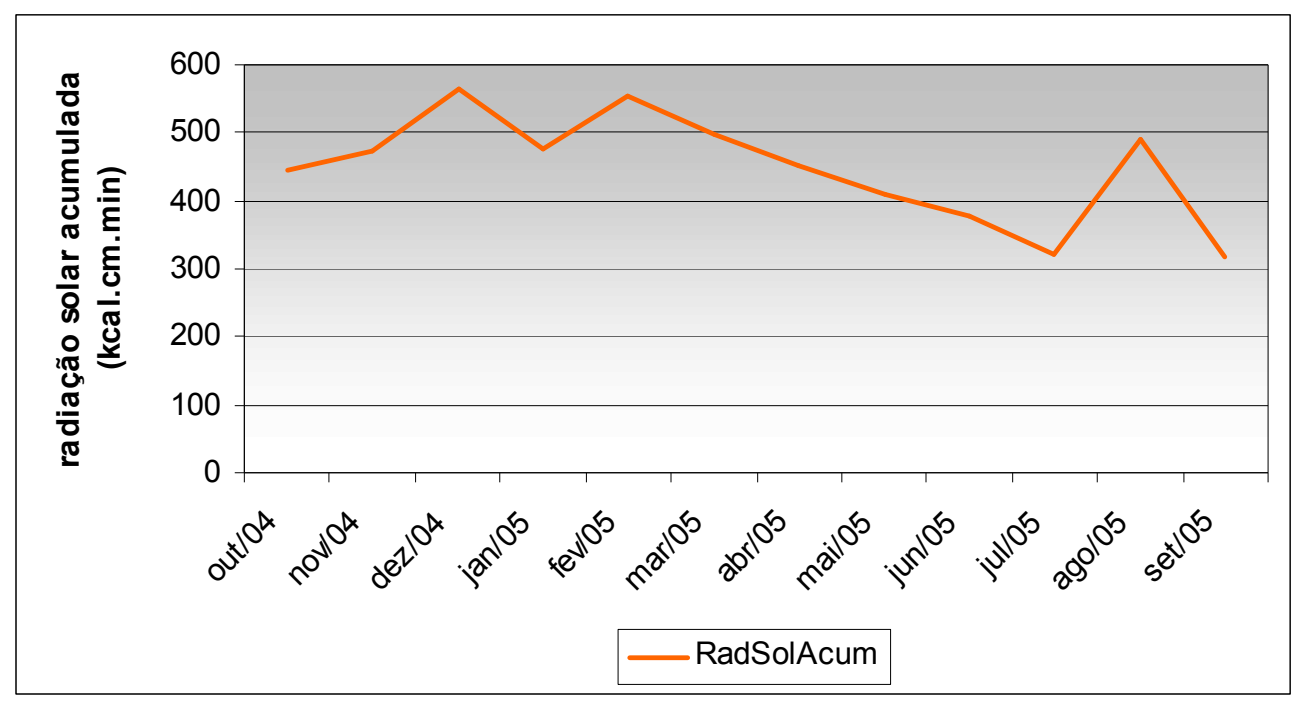

Figura 29 - Radiação solar acumulada média para a PCD Caraguatatuba durante 0 ano hidrológico 2004 e 2005.

Fonte: CPTEC (2006). 
Na primavera (out., nov. e dez.), no mês de dezembro, a radiação atinge seu máximo com $564,5 \mathrm{kcal} / \mathrm{cm}^{2} . \mathrm{min}$. No inverno (jul., ago. e set.) a quantidade de energia cai para a metade, com mínimo em $319,3 \mathrm{kcal} / \mathrm{cm}^{2} \cdot \mathrm{min}$, em setembro.

O outono (abr., mai. e jun.) e a primavera, apesar de transicionais, não apresentaram valores semelhantes. A característica marcante do outono é a gradual diminuição da energia que, ao contrário, na primavera, caracteriza-se pelo ganho até atingir os máximos, teoricamente, no verão (jan., fev. e mar.).

\subsection{Temperatura do ar}

Ao fornecer energia extra ao hemisfério mais iluminado, este se caracterizará, de forma geral, pelo aumento da sua temperatura sazonal, tanto atmosférica quanto oceânica.

$\mathrm{O}$ regime das temperaturas no $\mathrm{AH}$ 04/05 apresentou boa correlação com a radiação solar. Teoricamente, mais quantidade de radiação emitida pela superfície indica maior o aquecimento basal da atmosfera.

A Figura 30 mostra a média climatológica da temperatura do ar, média das máximas e das mínimas. Apresentou média climatológica da temperatura de $24,3^{\circ} \mathrm{C}$, com máximas em março de $2005\left(44^{\circ} \mathrm{C}\right)$ e mínima de $13^{\circ} \mathrm{C}$, em julho e agosto de 2005. A amplitude térmica média foi de $12,7^{\circ} \mathrm{C}$. 


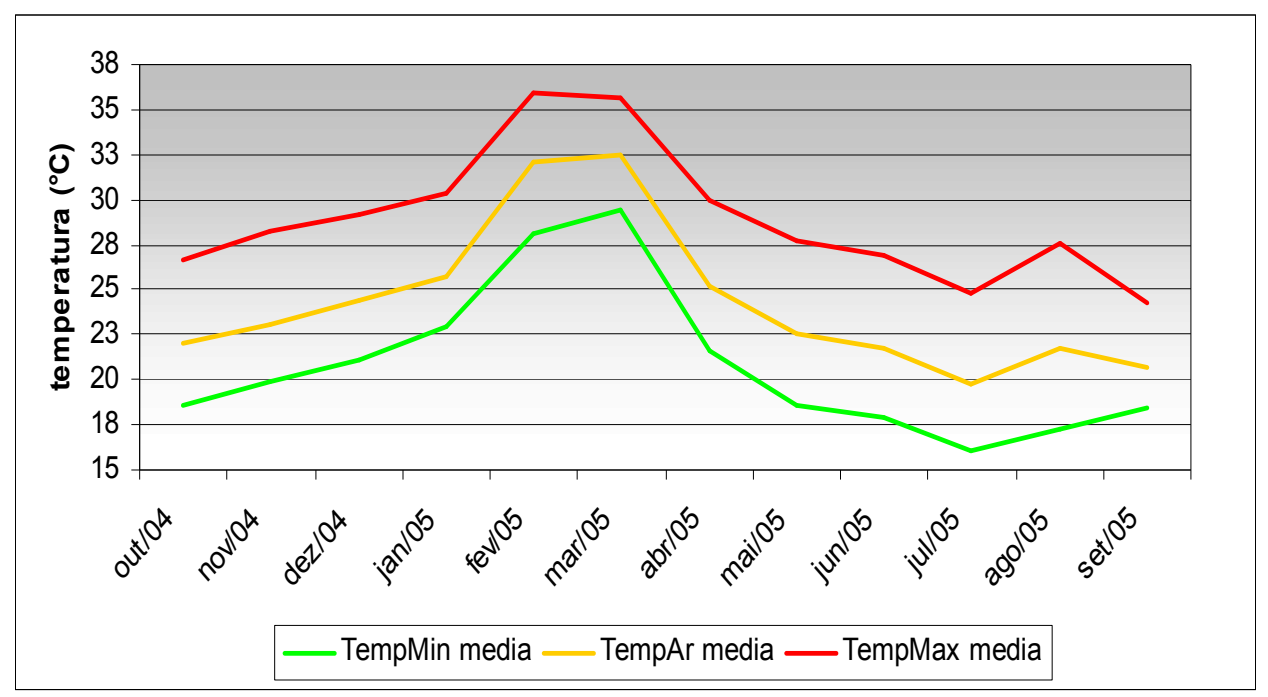

Figura 30 - Temperaturas média, média das máximas e média das mínimas para a PCD de Caraguatatuba durante o ano hidrológico 2004 e 2005.

Fonte: CPTEC (2006).

A primavera apresentou temperatura média de $23,2^{\circ} \mathrm{C}$, enquanto o verão, $30,1^{\circ} \mathrm{C}$. Já o outono registrou média na casa dos $23,2^{\circ} \mathrm{C}$ e o inverno, $20,7^{\circ} \mathrm{C}$. O mês de fevereiro foi considerado o mais quente com temperatura média das máximas em torno de $36^{\circ} \mathrm{C}$ e o mês mais frio foi julho de 2005 , com temperatura média das mínimas de $16,1^{\circ} \mathrm{C}$.

\subsection{Pressão Atmosférica}

As médias climatológicas mensais da pressão atmosférica e da moda mensal estão representadas na Figura 31. Nota-se a correlação inversa com as temperaturas médias. 


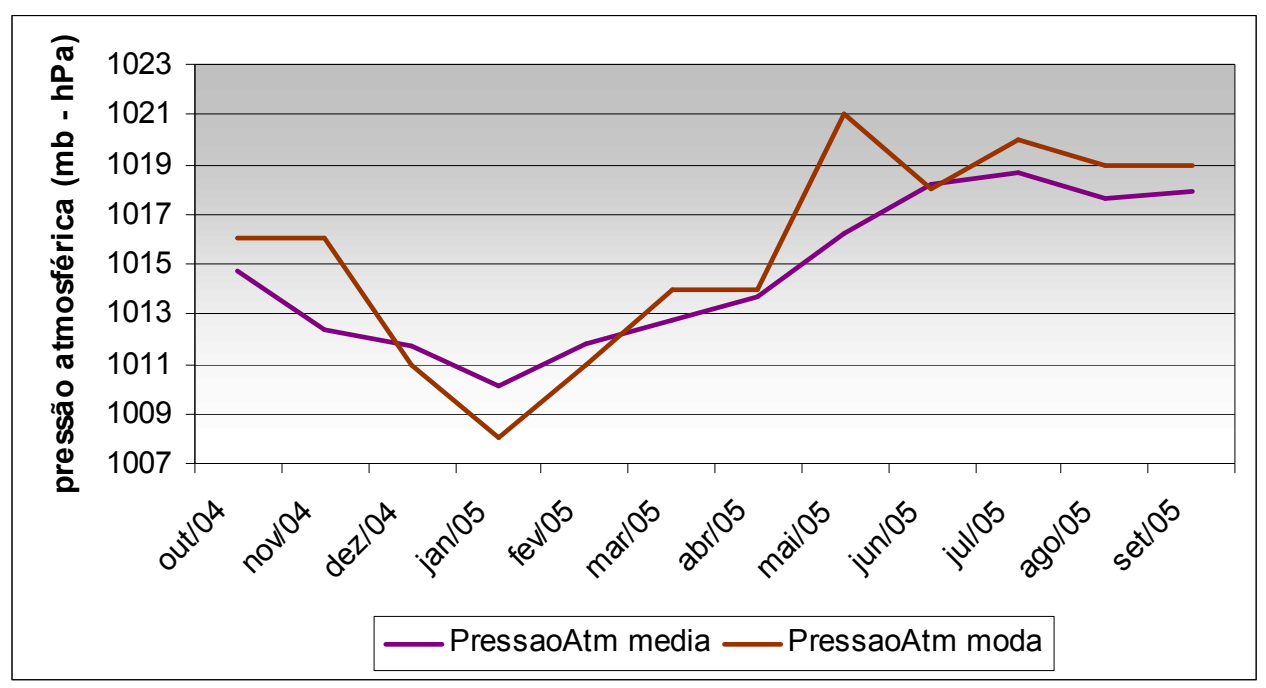

Figura 31 - Pressão média, para a PCD Caraguatatuba durante o ano hidrológico 2004 e 2005. Fonte: CPTEC (2006).

O regime da pressão atmosférica é bem definido. Com a elevação das temperaturas no período de primavera-verão o valor da pressão média diminuiu, assim como a moda (o valor de pressão mais freqüente foi $1008 \mathrm{mb}$, em janeiro). $\mathrm{O}$ contrário ocorreu no período do outono-inverno, quando os valores de pressão (moda de $1021 \mathrm{mb}$, em maio) aumentaram enquanto diminuíram as temperaturas. A variação média da pressão foi entre 1010,2 e 1018,6mb. Evidentemente a variação da pressão, neste caso, não é o indicativo de um controle local e sim, regional.

\subsection{Ventos}

Na Figura 32 são demonstradas a direção média e moda do vento e a direção média das máximas velocidades de vento. A direção média do vento e a direção média da velocidade máxima do vento encontram-se praticamente sobrepostas e 
apresentaram ventos predominantes do setor sul, tendendo a sudoeste no outonoinverno. Já a moda da direção do vento é na primavera-verão é de leste. No outonoinverno a moda do vento localiza-se a oeste.

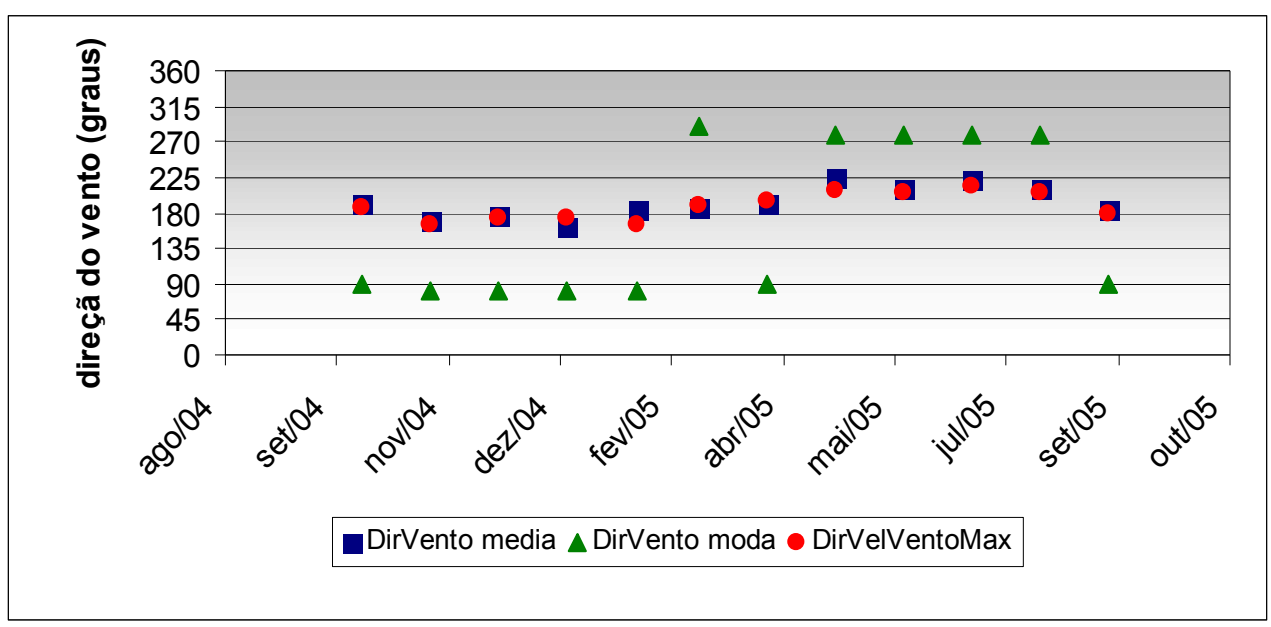

Figura 32 - Direção média do vento, direção média das velocidades máximas e moda da direção do vento para a PCD Caraguatatuba durante o ano hidrológico 2004 e 2005.

Fonte: CPTEC (2005).

As velocidades médias observadas variaram entre $10 \mathrm{~m} / \mathrm{s}$ (junho) e $14 \mathrm{~m} / \mathrm{s}$, em setembro. A média foi $11,8 \mathrm{~m} / \mathrm{s}$, no ano.

Sem dúvida, há influência canalizadora dos ventos devido à configuração morfológica do Canal de São Sebastião. Um estudo aprofundado do evento poderia melhor esclarecer o fato e fornecer informações mais adequadas sobre o quanto esses dados de vento podem estar viciados.

\subsection{Umidade Relativa do ar}

A análise da umidade relativa (Figura 33) durante o período observado não trouxe novidades quanto ao seu regime, dada a posição insular da área de estudo. 
Também apresenta correlação positiva com as outras constituintes do clima. Há pequena amplitude nos valores observados. No verão o aumento da umidade é patente assim como sua redução no inverno. A média de janeiro foi de $93 \%$ de umidade relativa presente no ar, enquanto outubro e agosto, obtiveram 76 e $78 \%$, em média.

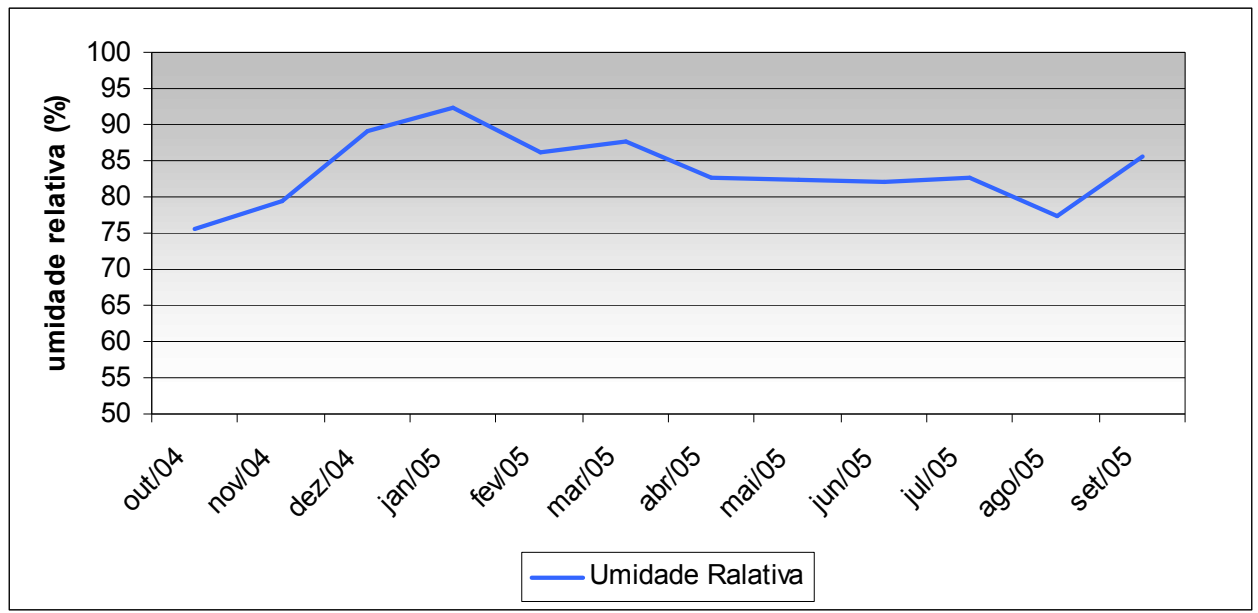

Figura 33 - Umidade relativa do ar média para a PCD Caraguatatuba durante o ano hidrológico 2004 e 2005.

Fonte: CPTEC (2006).

\subsection{Precipitação}

A Figura 34 apresenta os totais mensais de chuva e o valor máximo obtido em 24h para a PCD de Caraguatatuba. O valor mensal máximo de chuva obtido foi de 295,5mm, em março e o mínimo, 11mm, em agosto, com uma média climatológica mensal de $122,4 \mathrm{~mm}$ e total anual de $1468,8 \mathrm{~mm}$.

Os totais em $24 \mathrm{~h}$ apresentam chuva de intensidade considerada baixa. A média de $39,2 \mathrm{~mm}$ e reforça os resultados de Monteiro, 1973. Os totais máximos em $24 \mathrm{~h}$ 
foram observados em março e maio, 97,3 e $97 \mathrm{~mm}$, respectivamente. O menor total foi observado em agosto com 8,3mm.

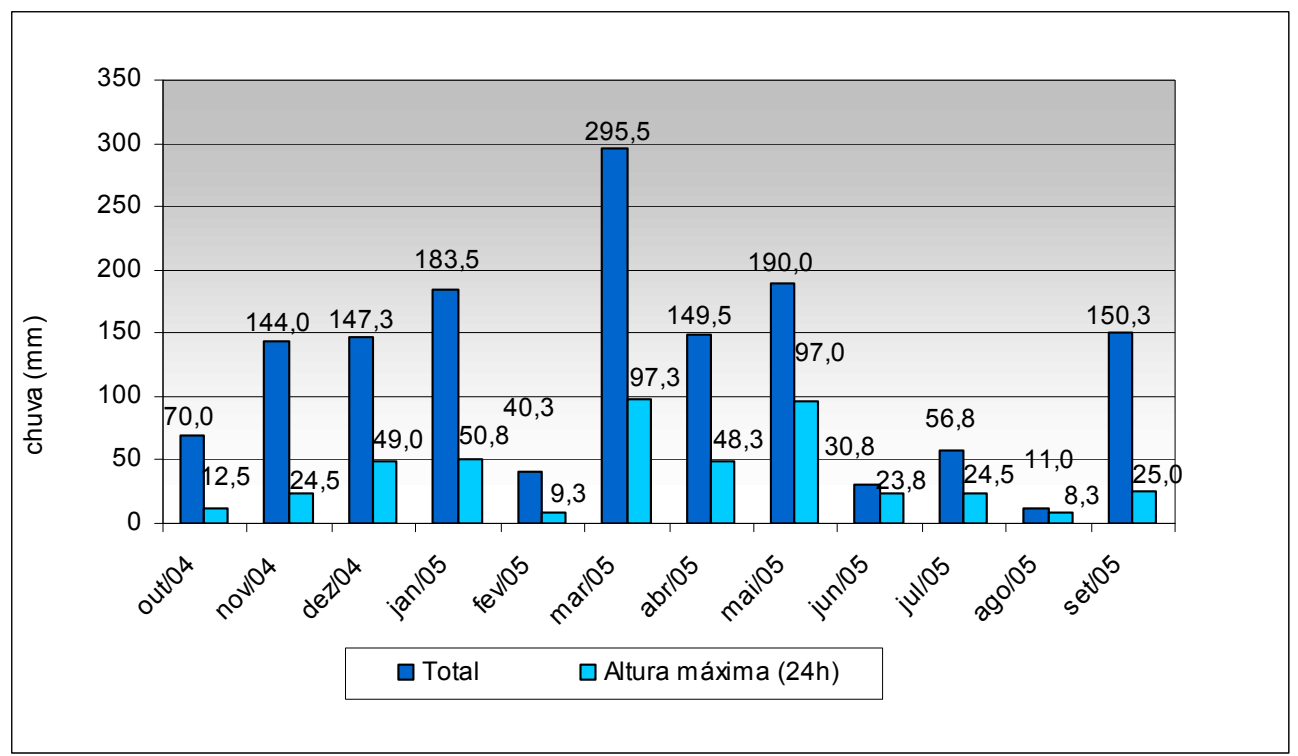

Figura 34 - Chuva totalizadora mensal e máximos em 24h para a PCD Caraguatatuba durante o ano hidrológico 2004 e 2005.

Fonte: CPTEC (2006).

De maneira geral, o regime da chuva na PCD mantém correlação negativa com as médias históricas dos postos do DAEE (Caraguatatuba e Porto Novo), apresentando um total anual de chuvas $20 \%$ menor, o que nos leva a acreditar que este ano hidrológico foi relativamente seco.

Os valores mensais da precipitação na PCD de Caraguatatuba que excederam as médias históricas foram de março, maio e setembro, $28,5 \%$ em média. Ao contrário, agosto registrou valor cinco vezes inferior à média.

Os eventos de chuva intensa em $24 \mathrm{~h}$, não parecem refletir a realidade regional e mantém correlação negativa, quando comparados aos valores do posto Ubatuba (INMET). Observada mais de perto, entretanto, mostra participação expressiva na contabilidade dos totais mensais de chuva, na média de $40 \%$. O que mais nos 
chama a atenção aqui são os valores de junho e agosto, quando os totais máximos de $24 \mathrm{~h}$ contribuíram, em média, com $76 \%$ do total precipitado em naqueles meses.

A situação de proximidade do posto Ubatuba aos contrafortes da Serra do Mar pode explicar os valores significativamente superiores aos da PCD de Caraguatatuba.

A Figura 35 representa a distribuição relativa dos totais sazonais da chuva. $A$ primavera contou com $24,6 \%$ e o outono com $25,2 \%$ dos valores de chuva durante o $\mathrm{AH}$ 04/05, demonstrando equilíbrio. Os valores do verão (35,4\% dos totais) confirmam ser esta a estação mais chuvosa do ano. A estação seca habitual, o inverno, conta com $14,8 \%$.

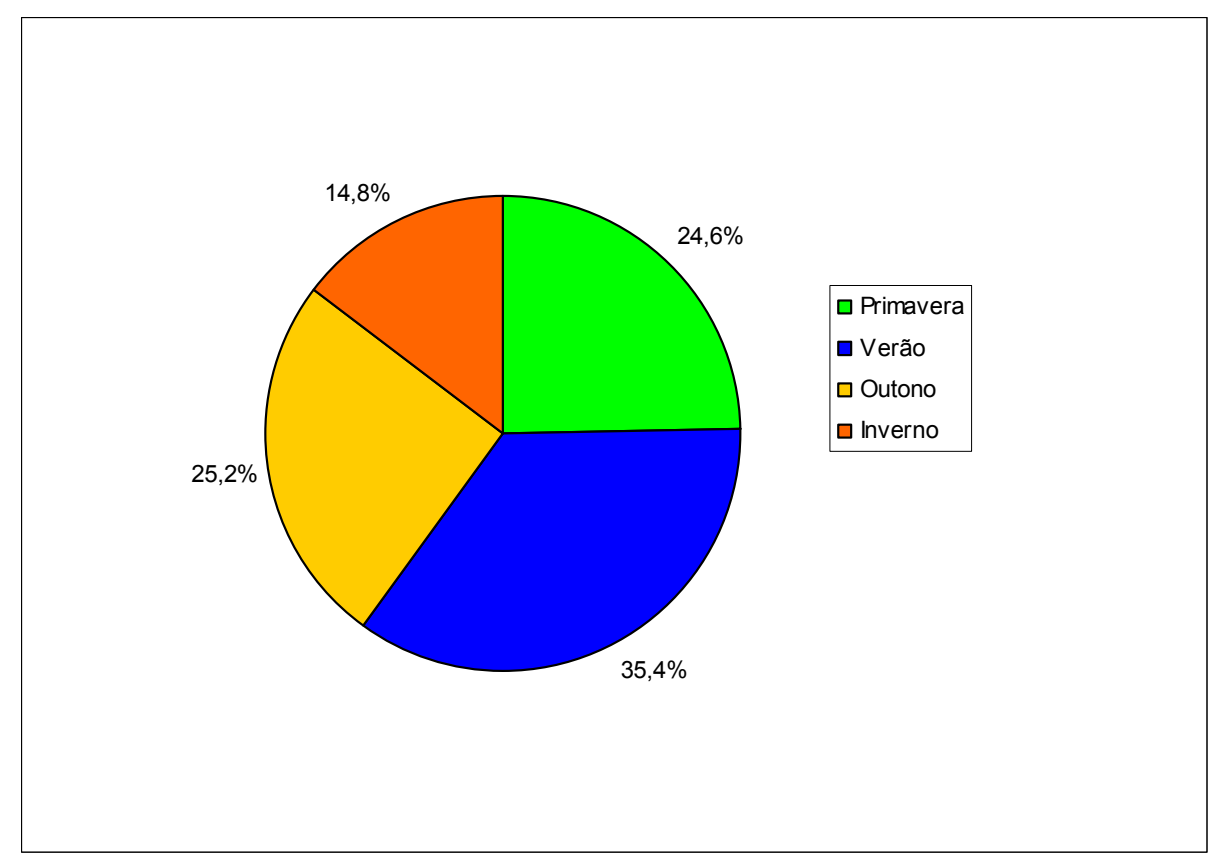

Figura 35 - Distribuição da chuva sazonal para a PCD Caraguatatuba durante o ano hidrológico 2004 e 2005.

Fonte: CPTEC (2006).

O período da primavera apresentou uma média de chuva de $120,4 \mathrm{~mm}$, no trimestre. O verão foi marcado com média na casa dos $173,1 \mathrm{~mm}$, com acréscimo médio de $30 \%$ sobre a primavera. O outono contou com precipitação média de 
$123,4 \mathrm{~mm}$, ou seja, $29 \%$ a menos que na estação anterior. O inverno correspondeu à diminuição dos valores, apresentando $72,7 \mathrm{~mm}$ de chuva (em média, $58 \%$ a menos que a estação mais chuvosa). Com exceção dos valores do outono, todos os são inferiores aos da média histórica para a estação.

Curiosamente, os valores de precipitação distribuem-se igualmente entre primavera-inverno e verão-outono, aproximadamente $50 \%$ de chuva para cada par.

\subsubsection{Gênese da Precipitação}

Sob a perspectiva adaptada de Tarifa (1975) podemos dizer que o AH 04/05 contou com $8,6 \%$ de fluxo polar direto em 31 dias de atuação e gerando $7,4 \%$ do total da chuva. O fluxo polar indireto participou com 25,2\% em 91,1 dias de atuação, apresentando chuvas representativas de $14,6 \%$ dos totais. O fluxo oscilante contabilizou $33,7 \%$ de atuação em 121,6 dias e precipitação de $32,8 \%$. Finalmente, o fluxo polar nulo apresentou participação de $15,6 \%$ em 56 dias, produzindo $26,4 \%$ da precipitação.

As indefinições entre os fluxos direto e indireto representaram $4,9 \%$ em 17,8 dias, tendo gerado $14 \mathrm{~mm}$ de chuva $(0,9 \%$ do total). Aquelas referentes aos fluxos oscilante e nulo apresentam 4,5\% de participação em 6,2 dias (chuvas totais de $49,5 \mathrm{~mm}$ ou $3,4 \%$ ). A classe barométrica média que faz referência às indefinições entre os fluxos polares indiretos e oscilantes, $1015 \mathrm{mb}$, participou com $7,1 \%$ das atuações em 25,6 dias com chuva de $213 \mathrm{~mm}$. 
Isso corresponde a 195 dias de atuação dos sistemas intertropicais que produziram $62,5 \%$ da precipitação para o $\mathrm{AH}$ 04/05. Os sistemas extratropicais participaram com 140 dias e geraram, apenas, 23\% da chuva. As indefinições entre ambos os sistemas representaram 26 dias com precipitação significativa de $14,5 \%$.

As quatro variações de fluxos polares maiores produtoras de chuva neste ano hidrológico em ordem crescente foram os oscilantes com $32,8 \%$ das chuvas de intensidade moderada, em seguida, o fluxo polar nulo com $26,4 \%$ e intensidade de chuva elevada. Em terceiro lugar vem as indefinições dos fluxos indiretos e oscilantes com $14,5 \%$ do total e mais elevada intensidade de chuva e o fluxo polar indireto com $14,6 \%$, porém, com intensidade reduzida. A responsabilidade da chuva pelo fluxo polar direto $(7,4 \%)$ fica abaixo daquele correspondente à análise de Monteiro (1973).

Em termos sazonais, a primavera apresentou maior freqüência dos fluxos oscilante e nulo $39,6 \%$ e $23,6 \%$ e, juntos respondem por $74,6 \%$ da chuva da estação. A definição do fluxo polar direto e a formação de chuva a ele associada foram insignificantes.

O verão, estação chuvosa, também foi marcado pela atuação $42,8 \%$ de freqüência do fluxo polar oscilante que gerou $30,6 \%$ da chuva e do fluxo nulo com $30,8 \%$ de participação e $29 \%$ da chuva. O fluxo polar indireto também se fez presente em $11,9 \%$ das vezes com produção de $20,2 \%$ da chuva. Também no verão não houve definição do fluxo polar direto.

O outono foi amplamente dominado pelos fluxos indireto, oscilante e por suas indefinições e atuaram com certo equilíbrio apresentando respectivamente $32,9 \%$, $33,6 \%$ e $9,4 \%$. São responsáveis por $14,8 \%$ (indireto), $30,7 \%$ (oscilante) e 19,2\% 
(indefinição ind./osc.) da chuva do período. Os fluxos polares diretos mostram-se significativos ao nível de $8,5 \%$ de atuação, mas ainda fracos na produção de chuva.

$\mathrm{Na}$ estação menos úmida, a freqüência dos fluxos polares diretos torna-se patente $(25,3 \%)$ assim como a sua responsabilidade para com a produção de chuva $(42,8 \%$ do total sazonal). Os fluxos polares indefinidos são os primeiros em participação $(38,4 \%)$, porém, geram pouca chuva $(18,8 \%)$.

Conforme o boletim de monitoramento climático CLIMANÁLISE, esse ano hidrológico teve participações abaixo da média histórica de frentes-frias e gerou poucos dias de chuva, 62 dias ou 17\% (Quadro 7), porém, durante abril, maio e junho, houve participação de frentes acima da média.

Quadro 7 - Climatologia de sistemas frontais, média histórica e ano hidrológico 2004-2005.

\begin{tabular}{|c|c|c|c|c|c|c|c|c|c|c|c|c|c|}
\hline Mês & Out & Nov & Dez & Jan & Fev & Mar & Abr & Mai & Jun & Jul & Ago & Set & Total \\
\hline $\begin{array}{c}\text { Méd. Histórica } \\
\text { Climanálise }\end{array}$ & 7 & 7 & 6 & 6 & 6 & 6 & 6 & 6 & 6 & 7 & 7 & 7 & 77 \\
\hline $\begin{array}{c}\text { AH 04/05 } \\
\text { Climanálise }\end{array}$ & 6 & 4 & 4 & 4 & 5 & 5 & 7 & 7 & 7 & 5 & 6 & 6 & 66 \\
\hline Dias com chuva & 5,1 & 8,1 & 5,5 & 9,6 & 4,0 & 6,4 & 4,5 & 3,3 & 1,8 & 3,9 & 0,9 & 8,8 & 61,8 \\
\hline
\end{tabular}

Monteiro (1973) e Tarifa (1975) relacionam anos secos às poucas invasões polares sobre o estado. A baixa dinâmica dos fluxos de sul que reduzem a freqüência de frentes frias sobre o litoral explica a ocorrência dos baixos valores de precipitação neste ano.

Quanto à participação das frentes acima da média nos meses de abril, maio e junho (outono) certamente explicam por que esses três meses tenham apresentado totais mensais elevados. A participação dos fluxos polares indiretos, oscilantes e suas indefinições na geração de $65 \%$ da chuva sazonal reafirmam esta condição. Por outro lado não explica a maior quantidade de precipitação mensal observada 295,5mm em março, nem o valor mínimo de agosto $(11 \mathrm{~mm})$. 
Em agosto, especificamente, as correntes associadas ao fluxo polar direto não geraram chuva. Aquelas ligadas aos fluxos polares indiretos precipitaram 2,3mm de chuva, porém, o maior montante foi é devido às correntes associadas ao fluxo oscilante, 8,5mm em 3h de duração. Foram 30 dias sem chuva, com predominância de atuação do fluxo polar indireto (15 dias).

Em março, apenas no evento chuvoso das $18 \mathrm{~h}$ do dia 24 às $6 \mathrm{~h}$ do dia 25, foi precipitado $50 \%$ da chuva mensal total, dada a indefinição completa das correntes atuantes que apresentaram ventos de oeste-noroeste associados à troca abrupta entre os valores barométricos que delimitam os fluxos indireto e oscilantes.

\subsection{A pluviometria da Estrada de Castelhanos}

A Tabela 1 apresenta a base de dados oficial a ser analisada. Constam aqui informações acerca do mês de referência dos trabalhos de campo e, a identificação dos postos e suas respectivas altitudes, além dos valores totais (mensal e por posto) e médios (mensal e por posto) de chuva que serão abordados a seguir.

Tabela 1 - Banco de dados pluviométricos referente ao ano hidrológico de 2004 a 2005 na Estrada de Castelhanos - Ilhabela (SP).

\begin{tabular}{|c|c|c|c|c|c|c|c|c|c|c|c|c|c|c|c|}
\hline Postos & Cota (m) & outt04 & now:04 & dez04 & janos & fewos & marros & $a b r, 05$ & mai,05 & jurvos & julvos & ago,05 & setios & Totais & Médias \\
\hline p1 & 3 & 81,8 & 145,3 & 1029 & 216,8 & 109 & 452,7 & 105,3 & 191,4 & 26 & 111.7 & 19.7 & 135,3 & 1758 & 270,5 \\
\hline $\mathrm{p} 2$ & 170 & 1108 & 181,7 & 188,3 & 298.7 & 115,1 & 463,3 & 279.8 & 197.4 & 39.4 & 96,9 & 19.4 & 187.7 & 21735 & 334,4 \\
\hline p5 & 600 & 203,5 & 263,4 & 395 & 3945 & 134,7 & 4633 & 465,1 & 304,6 & 85,3 & 1605 & 23,3 & 396,7 & 32899 & 506,1 \\
\hline$p^{7}$ & 600 & 190,8 & 336,1 & 434,2 & 607,4 & 215,6 & 7085 & 696,4 & 411,8 & 131,3 & 202,7 & 13 & 4239 & 4371,7 & 672,6 \\
\hline pg & 290 & 175,6 & 191,7 & 325,5 & 392,1 & 139,3 & 698,2 & 551,1 & 362,2 & 89 & 1605 & 23 & 3543 & 34625 & 532,7 \\
\hline \multirow[t]{3}{*}{$\mathrm{p} 12$} & 5 & 185,6 & 2062 & 344,3 & 335,6 & 111 & 5279 & 479.9 & 312,6 & 85,4 & 126.6 & 26.8 & 2949 & 30368 & 4672 \\
\hline & Totais & 948 & 1324,4 & 1790,2 & 2240.2 & 824,7 & 33139 & 2637.6 & 1780 & 456,4 & 8589 & 125,3 & 17928 & & \\
\hline & Médias & 158 & 220,7 & 298,4 & 373,4 & 1375 & 552,3 & 439,6 & 296,7 & 76,1 & 143,1 & 20,9 & 298,8 & & \\
\hline
\end{tabular}


Durante o $\mathrm{AH}$ 04/05 foi coletado um total de 18092,4 mm de chuva distribuída por seis postos pluviométricos que nos remete a uma média anual de $1507,7 \mathrm{~mm}$ ou 251,3mm por mês. Apresenta máximo de 708,5 mm em março, no p7, e mínimo de 13mm, também no p7, apresentando assim uma amplitude de $695,5 \mathrm{~mm}$.

A distribuição temporal dos valores de chuva é considerada normal quando comparadas às médias regionais. O total de chuva da PCD Caraguatatuba é $1468,8 \mathrm{~mm}$ (2,5\% menor). A média dos três postos da ilha é $1676,1 \mathrm{~mm} / \mathrm{ano}$. Individualmente, o posto Ilhabela apresenta média de 1509,6mm/ano.

A Figura 36 mostra a variação temporal da distribuição desses totais ao longo do ano. De maneira geral, os totais mensais se concentram nos meses de maior aquecimento (setembro a março) e, especialmente, em março quando a chuva acumulada foi 3313,9 $\mathrm{mm}$. O período de menor pluviosidade concentrou-se entre junho e agosto, sendo este último mês, o que apresentou menor total pluviométrico 125,3 mm, reforçando a idéia de sua amplitude e variação. Apresenta alta correlação temporal mensal com outros postos da região.

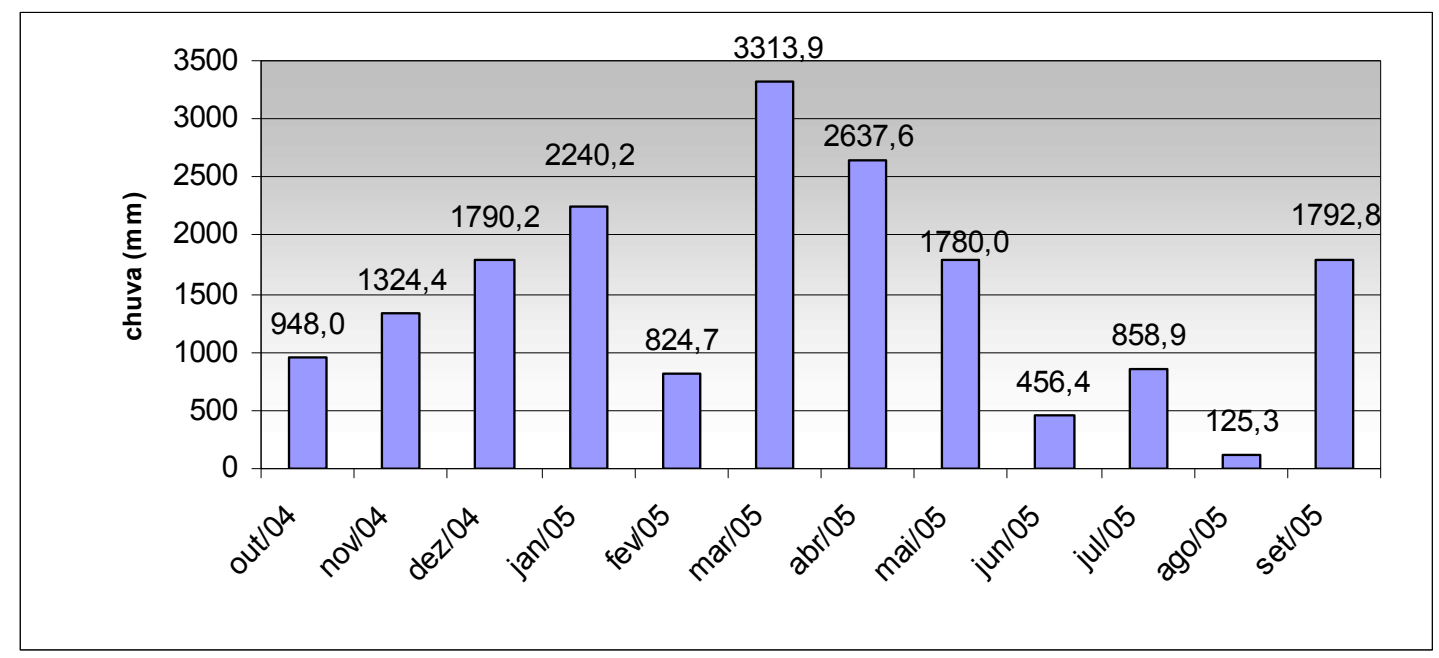

Figura 36- Distribuição mensal dos totais de chuva para o ano hidrológico de 2004/2005 na Estrada de Castelhanos, Ilhabela (SP). 
Na Figura 37 observa-se a distribuição dos totais relativos de chuva, por estação do ano. No primeiro trimestre do ano hidrológico, de outubro a dezembro de 2004 (primavera), choveu 22\% do total (média de 1354,2mm), sendo o início do período das chuvas, quando o hemisfério sul volta a se aquecer. O trimestre do verão (entre janeiro a março de 2005) colabora com os maiores valores relativos, $36 \%$ do total $(2126,3 \mathrm{~mm}$, em média). O outono (abril, maio e junho de 2005) demonstra já o início da redução dos totais com $27 \%$ de chuva (média de 1624,7mm). E, finalmente, ao final do ano hidrológico, o inverno demonstra os menores valores de precipitação acumulada, em torno de $15 \%(925,7 \mathrm{~mm}$, em média).

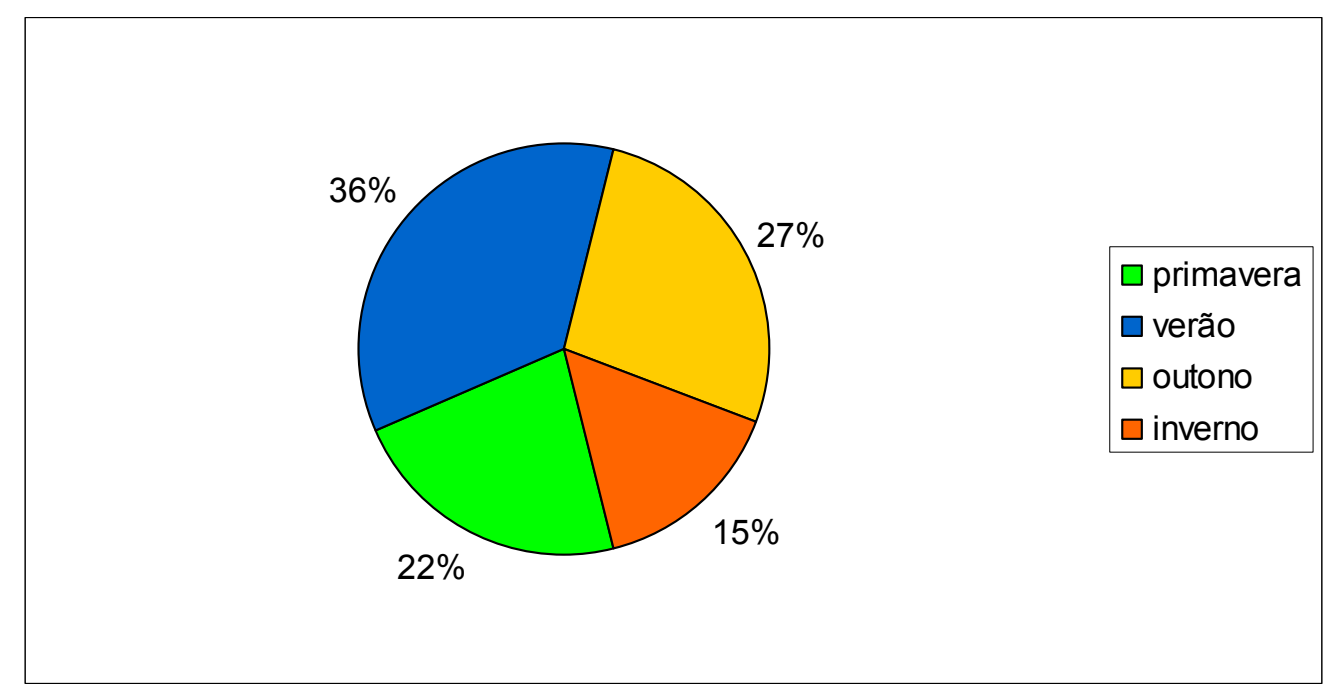

Figura 37 - Distribuição sazonal dos totais de chuva para o ano hidrológico de 2004/2005 em Ilhabela.

As distribuições dos valores sazonais de precipitação em llhabela são levemente superiores (5\%) do que aquilo observado na PCD de Caraguatatuba Tais quantidades de chuva estão acima daquelas observadas por Conti (1975) e abaixo daquelas de Monteiro (1973). 
É certo que a elevada participação dos fluxos polar oscilante e nulo, preponderantemente e, em menor freqüência às correntes associadas ao fluxo indireto atuaram de maneira mais ou menos uniforme sobre a área de estudo gerando a maior parte da precipitação coletada. Este ano hidrológico não teve suas chuvas geradas em maior parte pela atuação das frentes-frias, mas pela intensa dinâmica das trocas atmosféricas realizadas entre os sistemas extratropicais e intertropicais, que confirmam a encruzilhada de fluxos de ar a que se refere Monteiro (1973).

A Figura 38 apresenta a resposta média de chuva dos postos do INMET e DAEE da região do litoral norte paulista ao longo de suas séries históricas. Também apresenta, ainda de forma comparativa, os totais mensais da PCD de Caraguatatuba e os valores da média climatológica mensal dos dados dos trabalhos de campo.

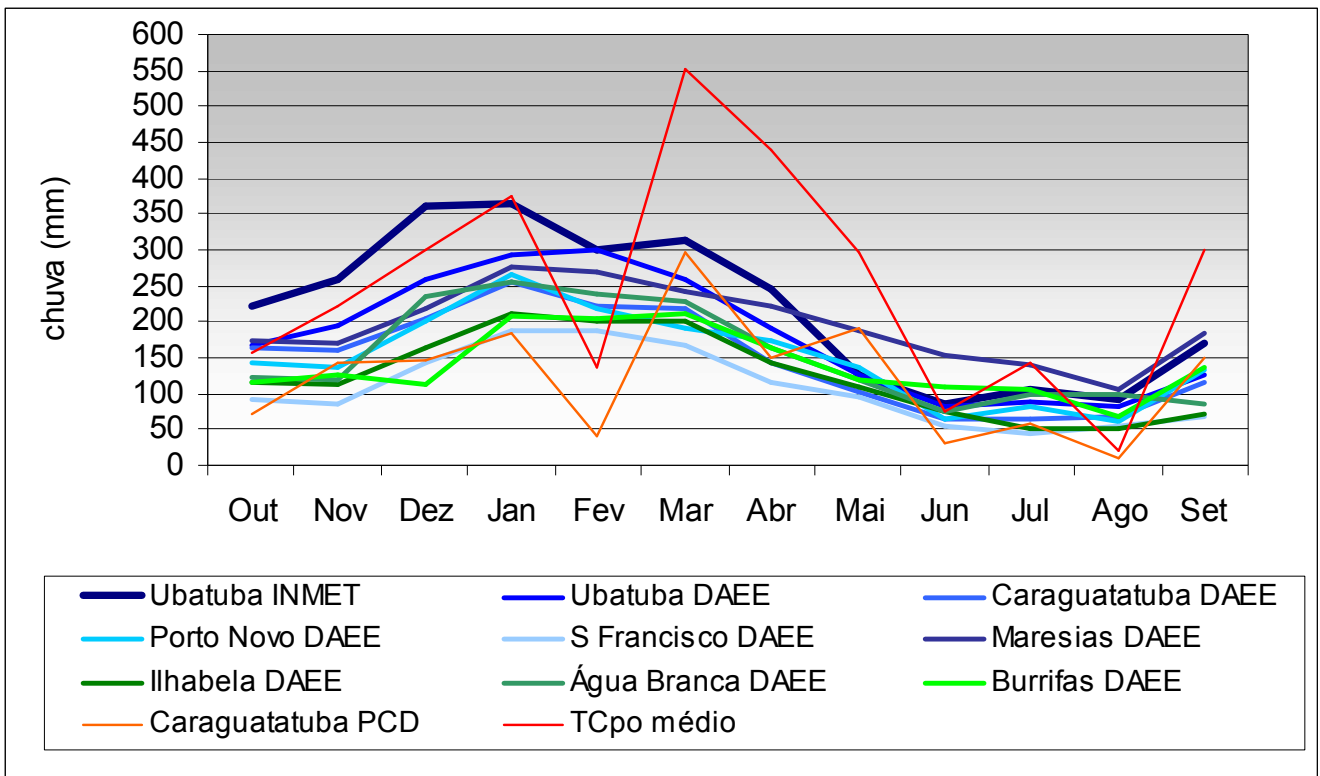

Figura 38 - Precipitação mensal para os postos do INMET e DAEE, PCD de Caraguatatuba e dos dados observados nos pluviômetros instalados na Ilha de São Sebastião para o ano hidrológico de 2004/2005.

As linhas mais suaves dos postos do INMET e do DAEE são reflexos de suas longas séries históricas. Pode-se notar uma tendência média em todos os meses do 
ano hidrológico, incrementos de chuva de outubro a março (estação chuvosa) e queda conseqüente dos totais entre abril e agosto (estação menos chuvosa). Inferimos aqui que, apesar da menor série histórica computada, posto DAEE (Usina Água Branca) com 17 anos, nos faz perceber a existência clara de um regime pluviométrico regional. Não nos cabe, pelo momento, uma análise mais aprofundada. Podemos, entretanto, notar que os valores totais da PCD Caraguatatuba e da média dos trabalhos de campo, à primeira vista, díspares do regime habitual da chuva, têm valores aproximados com relação às médias, pois que esses dados locais têm um ritmo mensal semelhante àqueles regionais. É necessário dizer ainda que as curvas de Caraguatatuba (INPE) e do trabalho de campo não refletem a "suavidade" das curvas médias históricas, haja vista o período tempo bem menor ao qual foram coletadas.

A Figura 39 referencia a variação mensal da chuva coletada nos postos instalados na Estrada de Castelhanos e da chuva registrada pela PCD em Caraguatatuba e apresentam boa correlação linear, sugerindo confiabilidade aos dados observados.

De maneira geral os postos "conversam" entre si com homogeneidade, sendo possível identificar um ritmo entre eles. Durante o ano hidrológico, distribuição espacial da chuva ocorreu de maneira, mais ou menos uniforme, nos períodos menos úmidos todos os postos apresentaram convergência para valores reduzidos e nos meses chuvosos, apresentaram valores mais elevados. 


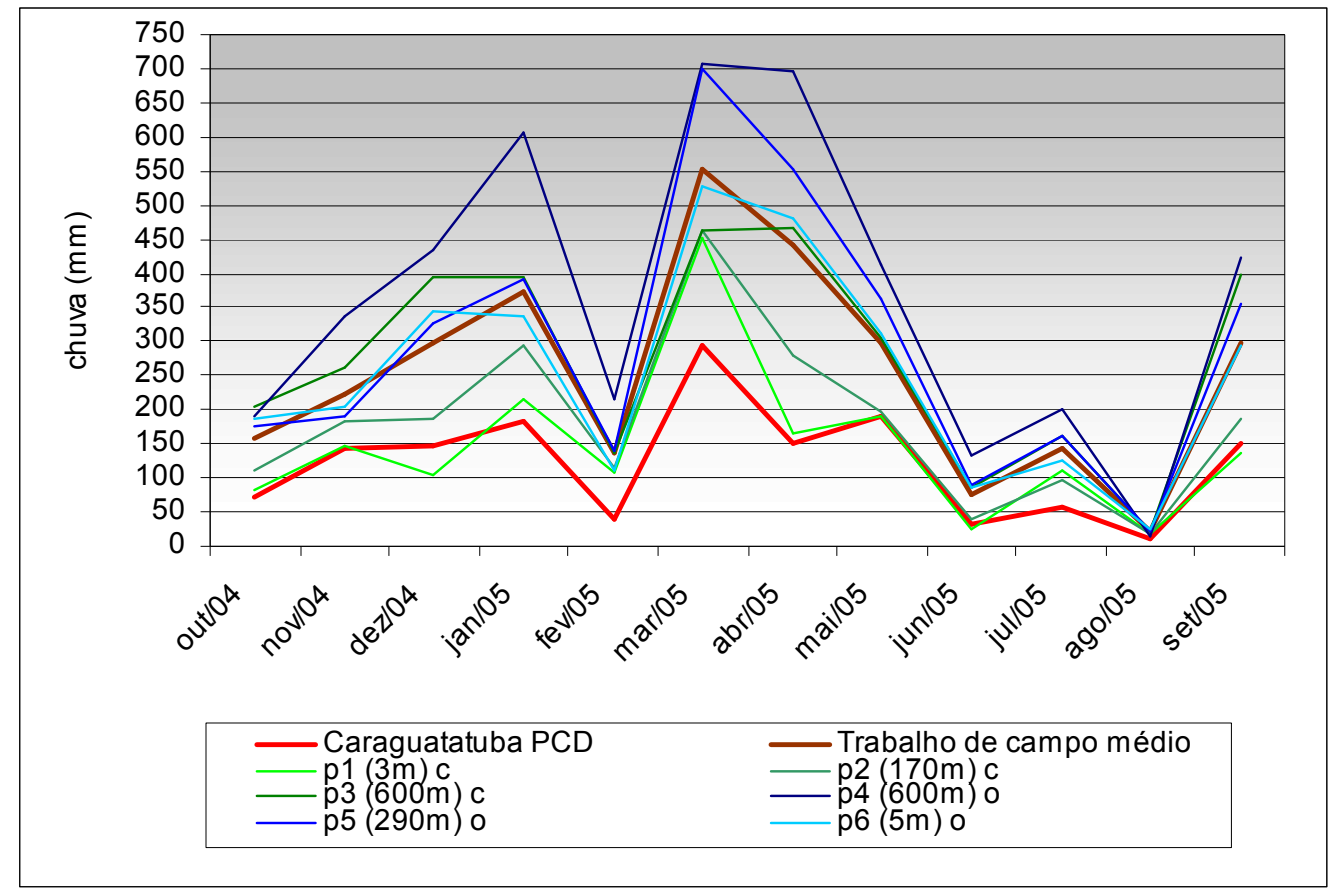

Figura 39 - Precipitação mensal para os postos Caraguatatuba (PCD), p1, p2, p3 (vertente continental), p4, p5 e p6 (vertente oceânica), além da média do Trabalho de Campo para o ano hidrológico de 2004/2005.

O primeiro ponto a detalhar é com relação aos valores da PCD de Caraguatatuba $(10 \mathrm{~m})$, praticamente os menores de todas as observações, com máxima de 295,5mm (março) e mínima de $11 \mathrm{~mm}$ (agosto). Possivelmente, a posição geográfica deste posto, dentro da área de sombra de chuva provocada pela ilha em direção ao continente, seja a influência predominante.

A diferença de valores acima da média apresentados por p7 e p9, evoca a questão do relevo. Nos meses de chuva (outubro a março), mantém uma certa eqüidistância da média. Mas é nos meses de transição do verão para o outono ou do $2^{\circ}$ para $\circ 3^{\circ}$ trimestre do ano hidrológico analisado que essa diferença torna-se patente. Os valores máximos de chuva coletados por p7 $(708,5 \mathrm{~mm})$ e p9 $(698,2 \mathrm{~mm})$ em março e, 696,4mm em p7 e 551,1 mm em p9, em abril, se contrastados com o valor médio $552,3 \mathrm{~mm}$ e $439,6 \mathrm{~mm}$, em março e abril, respectivamente teremos 
diferenças entre 150 e 180mm, que podem ter uma causalidade orogênica. Por isso demandando de investigação posterior.

A Figura 40 representa o desvio relativo dos valores totais de chuva dos postos da Ilha de São Sebastião em relação aos do PCD Caraguatatuba. Expressa uma idéia de variabilidade percentual dos dados de campo com relação à sua diferença ao PCD.

A correlação observada é positiva para os postos da Estrada de Castelhanos em quase $90,5 \%$ das observações de campo. Comparadas por vertente, a continental tem desvio médio de $79,1 \%$ e a oceânica $162,5 \%$. Os postos p1 em março, p2 em março e abril, p5 em abril, p7 em janeiro, março e abril, p9 em março e abril e, p12 em março e abril, apresentam seus desvios relativos máximos.

Considerando a situação geográfica de abrigo e exposição das vertentes na localização de cada posto utilizado aqui, que resume a condição topográfica de seus sítios, não é de se estranhar que os postos situados em altitudes superiores a 300m possuam maior desvio relativo. A maior freqüência dos desvios está em torno de 50 a $250 \%$, mas os maiores desvios aparecem nos meses com quantidades de chuva maiores. Acima dos $250 \%$ de desvio relativo estão 4 ocorrências para p7 e apenas uma para p9.

Se os meses com maiores quantidades de chuva são aqueles com os maiores números de passagens de frentes frias, então o mecanismo semeador - alimentador de Bergeron (1968) faz a diferença na avaliação da orografia local. Caso contrário, a autoconversão e a convecção disparada devem ser considerados. 


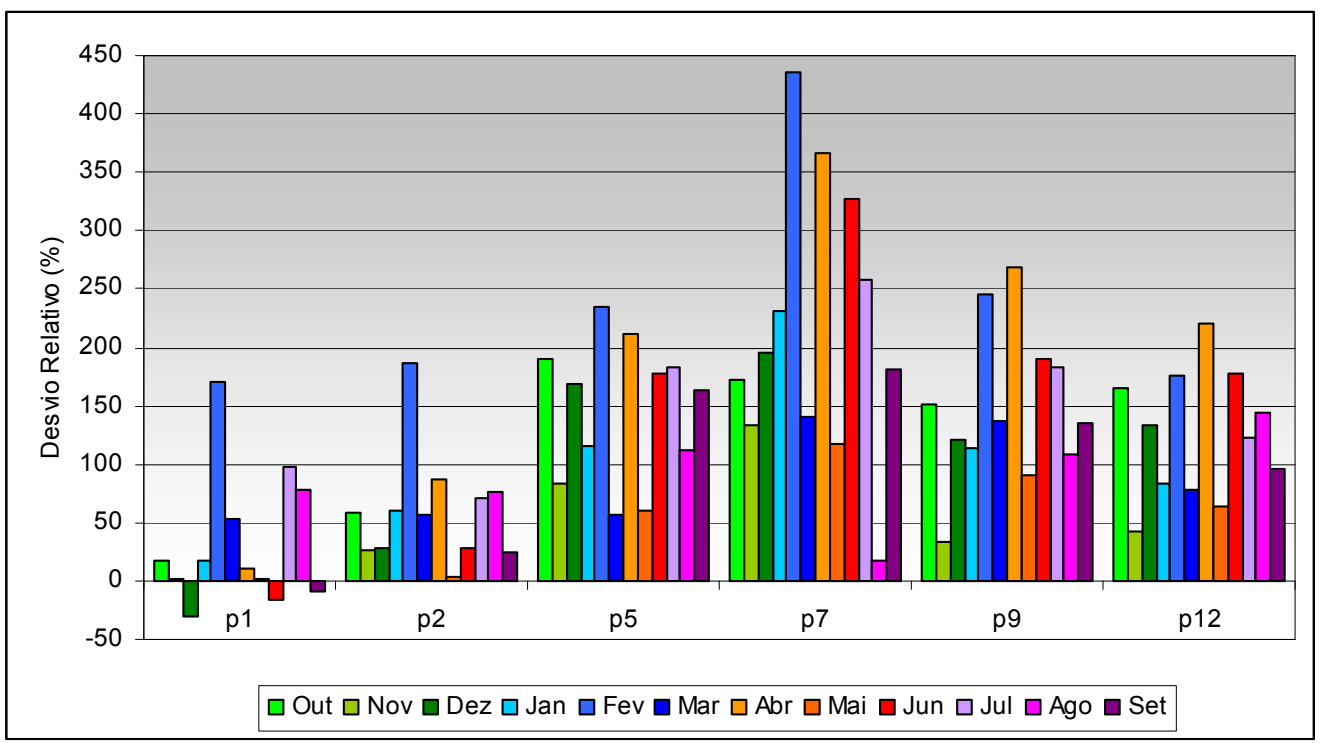

Figura 40 - Desvios relativos dos valores de chuva entre os postos de llhabela e o PCD Caraguatatuba para o ano hidrológico de 2004/2005.

Na Tabela 2 encontram-se representados os dados da Figura 38. Chamamos a atenção para o fato de que nem todos os postos apresentam valores superiores à PCD de Caraguatatuba. Os desvios negativos concentrados em $\mathrm{p} 1$, realçados em negrito na tabela, confirmam a existência de uma localidade bem pouco chuvosa na ilha.

Tabela 2: Desvios relativos ao total mensal da precipitação dos postos pluviométricos em relação ao posto Caraguatatuba (INPE) durante o ano hidrológico de 2004/2005.

\begin{tabular}{|l|l|l|l|l|l|l|l|l|l|l|l|l|}
\hline & out/04 & now/04 & dez/04 & jan/05 & fev/05 & mar/05 & abr/05 & mai/05 & jun/05 & jul/05 & ago/05 & set/05 \\
\hline p1 & 16,8 & 0,9 & $-\mathbf{3 0 , 1}$ & 18,1 & 170,8 & 51,1 & 10,6 & 0,7 & $\mathbf{- 1 5 , 3}$ & 96,9 & $\mathbf{7 8 , 9}$ & $\mathbf{9 , 9}$ \\
\hline p2 & 58,3 & 26,2 & 27,9 & 60,1 & 185,9 & 54,7 & 87,1 & 3,9 & 28 & 70,7 & 76,2 & 24,9 \\
\hline p5 & 190,7 & 82,9 & 168,2 & 115 & 234,8 & 54,7 & 211,1 & 60,3 & 177,4 & 182,8 & 112 & 164 \\
\hline p7 & 172,5 & 133,4 & 194,9 & 231 & 435,6 & 136,6 & 365,8 & 116,7 & 326,9 & 257,2 & 18,4 & 182,1 \\
\hline p9 & 150,9 & 33,1 & 121,1 & 113,7 & 246 & 133,1 & 268,6 & 90,6 & 189,5 & 182,8 & 109,2 & 135,8 \\
\hline p12 & 165,2 & 43,2 & 133,8 & 82,9 & 175,8 & 76,3 & 221 & 64,5 & 177,7 & 123 & 144,1 & 96,3 \\
\hline
\end{tabular}

Fazendo uma consideração semelhante à anterior, com relação à situação de abrigo e exposição dos postos, o p1 está situado na planície litorânea da vertente continental, relativamente próximo à morraria da ilha. Parece-nos estar na situação mais abrigada de todos os postos pluviométricos, realçando a sombra de chuva. 
Este é um efeito da variabilidade da chuva no espaço ou da influência de uma circulação terciária gerada pela canalização do vento no canal de São Sebastião.

Não dispondo de dados sistematizados da brisa do mar no local, mas crendo na formação orográfica de nuvens baixas a partir deste movimento do ar, quase que constante nas encostas oceânicas da ilha, dada a presença do oceano, somadas à nebulosidade e resfriamento da temperatura do ar típica da passagem das frentes frias, é possível acreditar que as nuvens mais altas semeiem gotas sobre a nuvem de altitude inferior, intensificando os processos de manutenção da nebulosidade e formação da chuva orográfica.

Na Figura 41 podemos ver a variação dos valores sazonais totais pelas vertentes opostas na Ilha de São Sebastião. O lado continental apresenta-se em média, $20 \%$ menos úmido que o lado oceânico, sendo que no $1^{\circ}$ trimestre do ano hidrológico (primavera) a diferença é de $4 \%$, no verão é de $6 \%$, com $7,5 \%$ no outono e, a menor diferença no inverno com $2,6 \%$.

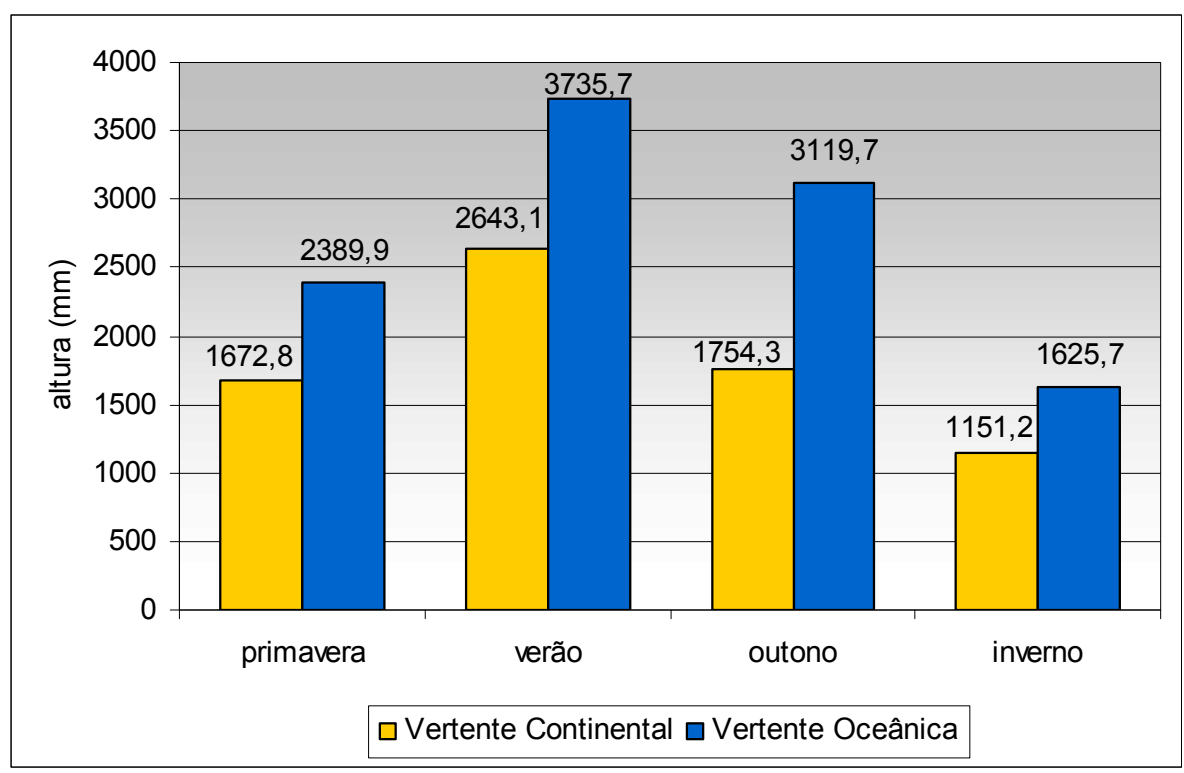

Figura 41 - Variação da chuva trimestral acumulada em todos os postos de cada vertente na Estrada de Castelhanos, para o ano hidrológico de 2004/2005. 
O escoamento do ar a barlavento gera chuva em maiores altitudes, pois as temperaturas são menores e, portanto, a formação de nuvens e chuva, mais intensa.

A Figura 42 apresenta o total pluviométrico anual acumulado obtidos por cada posto no decorrer do ano hidrológico e sua variação mensal. Cremos ser este o gráfico mais importante deste estudo, pois, demonstra com propriedade, a distribuição espacial da chuva dentro do transecto Estrada de Castelhanos onde, em função da altitude, os pluviômetros experimentais foram instalados.

Podemos notar, ainda sem considerar valores absolutos, dois blocos de resultados. Um primeiro bloco representado pelos postos p1 e p2 com valores anuais intermediários entre 1500 e $2500 \mathrm{~mm}$ e, um outro representado pelos postos restantes com valores anuais acima dos $3000 \mathrm{~mm}$. Chamamos a atenção para o fato de que independentemente deste ano hidrológico ser considerado normal, chuvoso ou seco, os valores obtidos aproximam os três postos "castelhaneiros" dos mais chuvosos da região; em Ubatuba, a média anual é de 2171m (Milanesi,2004), no posto do DAEE a $5 \mathrm{~m}$ de altitude. 


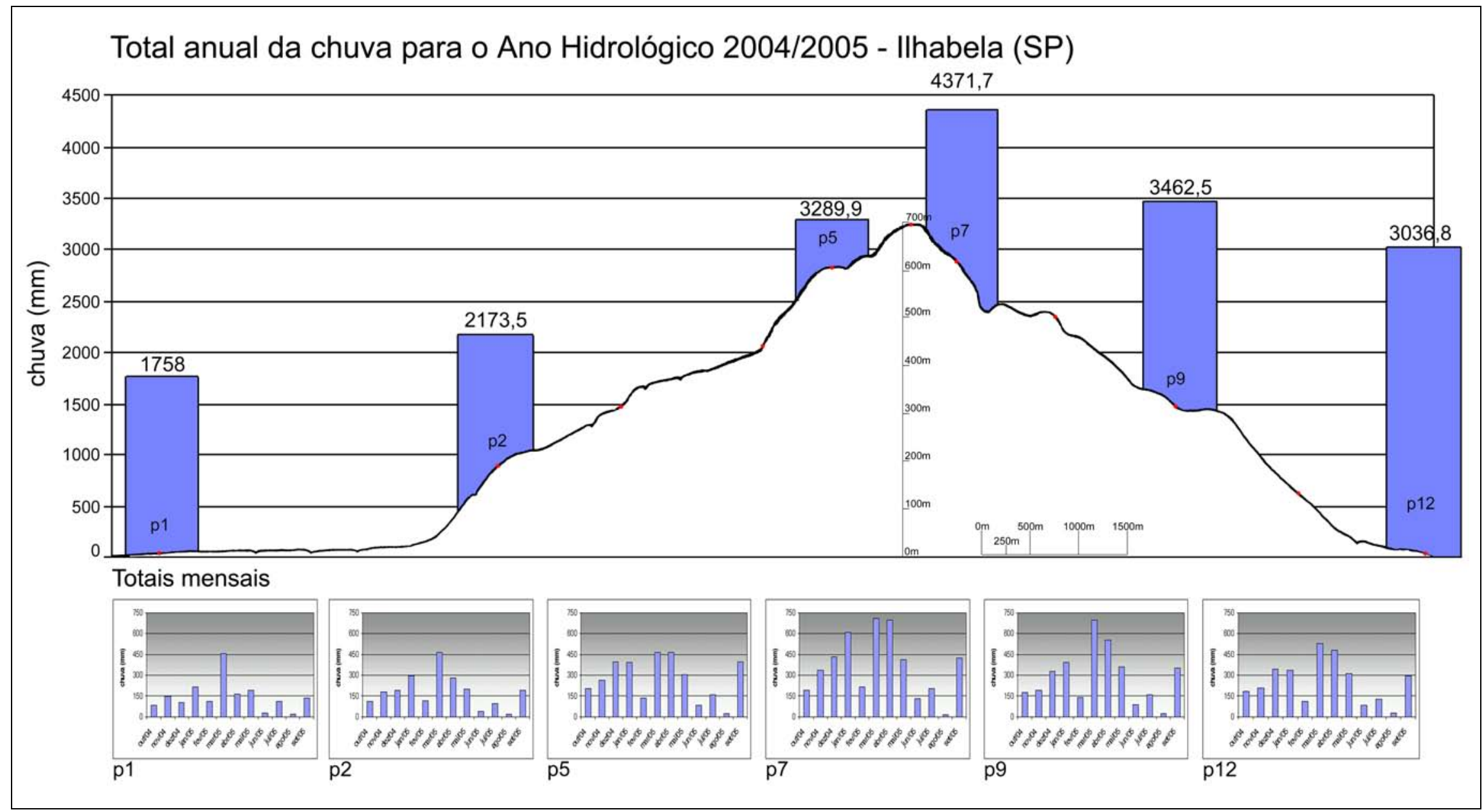

Figura 42 - Variação espacial da chuva para o ano hidrológico de 2004/2005, em llhabela. 
Em ordem crescente o posto $\mathrm{p} 1$ foi aquele que acumulou menores quantidades de chuva (1758mm), p2 apresenta acumulados de $2173 \mathrm{~mm}$ no ano, p12 com $3037 \mathrm{~mm}$. Já os postos p5 e p9, respectivamente apresentam 3290 e 3462mm de chuva acumulados e, finalmente, o posto mais chuvoso com $4372 \mathrm{~mm}$, p7.

Pensando nessa distribuição em termos da exposição geral das vertentes da ilha, os postos 1, 2 e 5 localizados na vertente continental, apresentam um somatório acumulado de $30 \%$ menor que p7, p9 e p12 juntos. Aqui indubitavelmente vemos, o controle do relevo na distribuição dessa precipitação entre o sotavento e o barlavento da Estrada de Castelhanos, que significa dizer que chove mais a barlavento. O que nos leva à apropriação da relação do aumento dos índices de chuva na medida em que se eleva o terreno.

A Figura 43 revela um pouco mais que a comparação entre os totais mensais dos postos de planície, p1 $(3 \mathrm{~m})$ a sotavento e p12 $(5 \mathrm{~m})$ a barlavento da llha de São Sebastião e a PCD de Caraguatatuba (10m), também situado em planície.

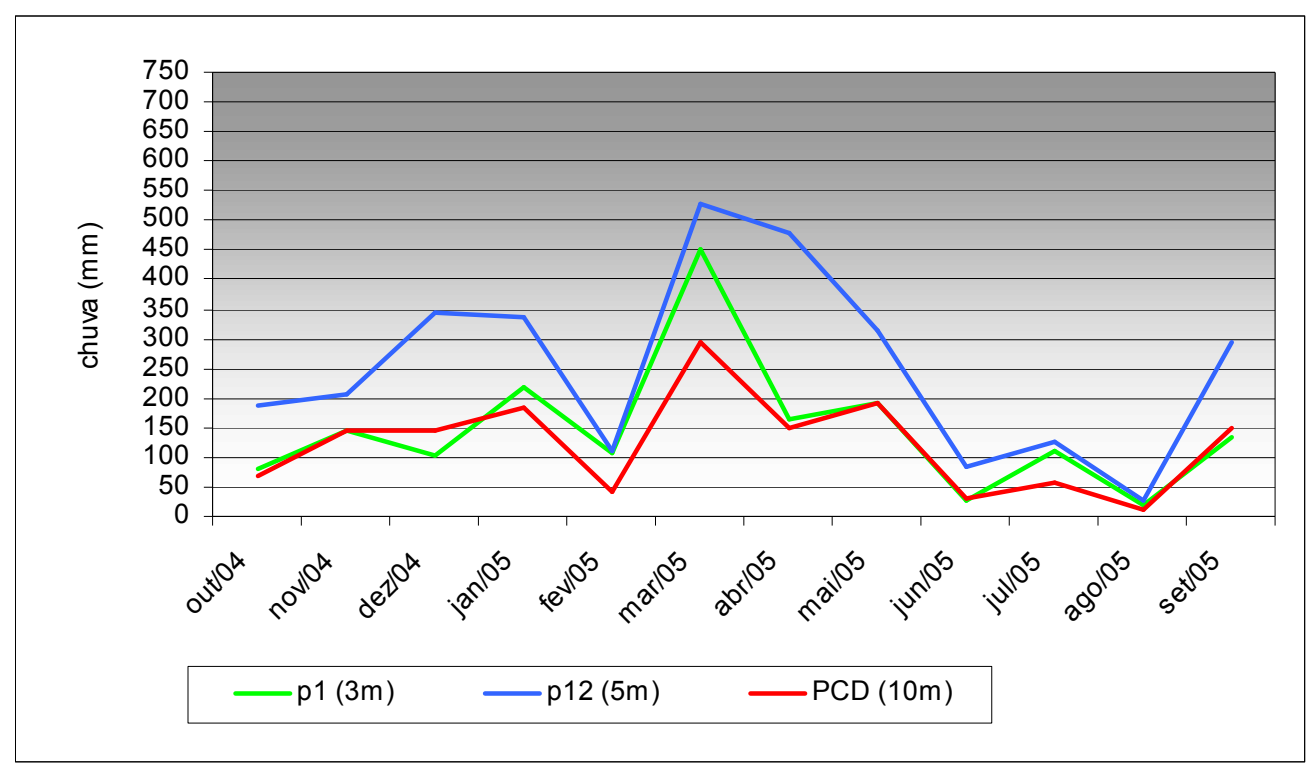

Figura 43 - Comparação entre os postos de planície quanto à variação espacial da chuva para o ano hidrológico de 2004/2005, em Ilhabela. 
Entre $\mathrm{p} 1$ e p12, há diferenças significativas entre os valores mensais de chuva com exceção de fevereiro e agosto. O posto p1 está em situação de abrigo absoluto aos fluxos atmosféricos e recebe as menores quantidades de chuva da série. $\mathrm{O}$ posto p12 está à meia distância entre o sopé do maciço e a praia, porém, completamente desobstruído aos ventos predominantes de sudeste, que justifica suas maiores quantidades de chuva.

A relação entre os valores de chuva entre $\mathrm{p} 1$ e a PCD de Caraguatatuba apresenta os desvios relativos menores de toda a série, incluindo os desvios negativos de dezembro, junho e setembro. A correlação entre eles é boa, possivelmente pela pequena distância que os separam e pelos sítios de instalação abrigados aos ventos predominantes.

A Figura 44 também é comparativa dos totais mensais de chuva entre os postos de meia vertente p2, a 170m (vertente continental) e p9, a 290m, na vertente oceânica da Estrada de Castelhanos, mais a PCD de Caraguatatuba.

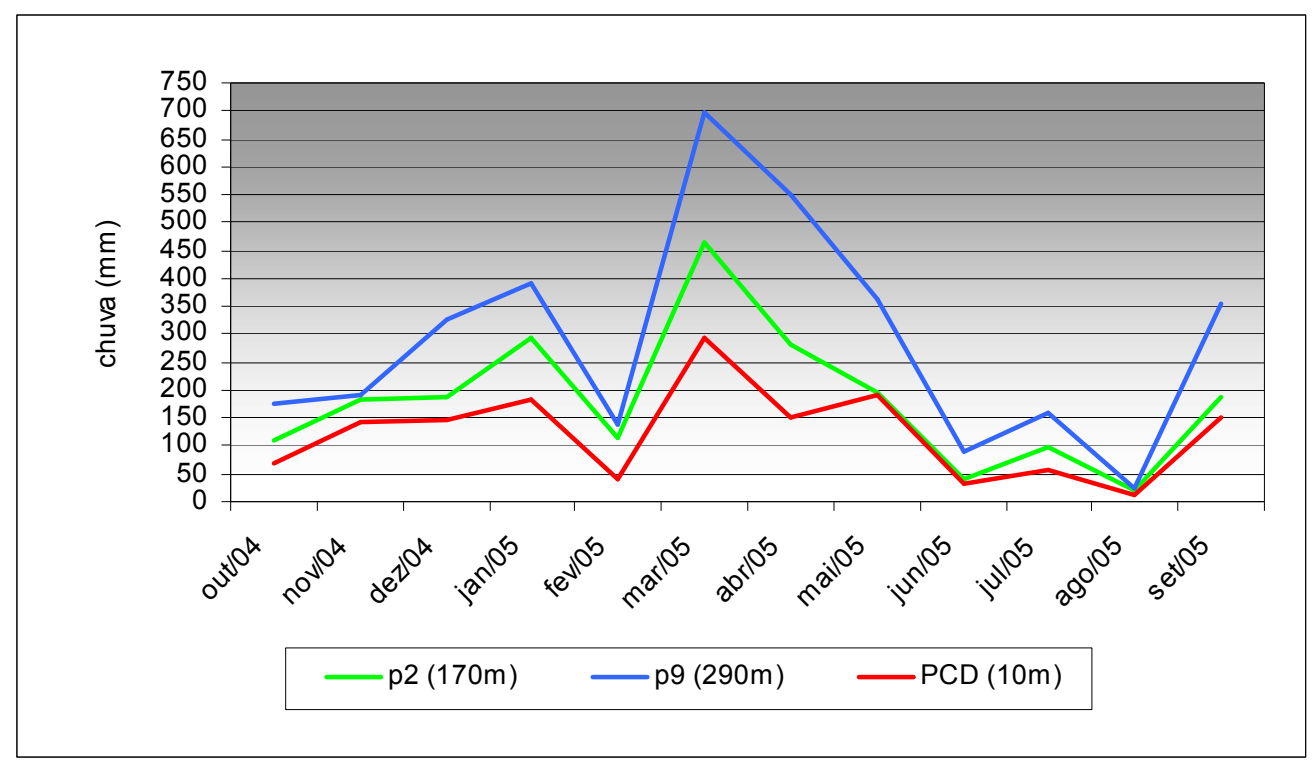

Figura 44 - Comparação entre os postos de vertente quanto à variação espacial da chuva para o ano hidrológico de 2004/2005, em Ilhabela. 
Também pode-se observar diferenças significativas no acumulado da chuva mensal entre p2 e p9, com exceção dos meses de novembro, fevereiro e agosto. Os menores valores de p2 podem estar relacionados à sua situação de abrigo, assim como aos fluxos descendentes "ressecados" que caracterizam a sombra de chuva. O posto p9 está no limite da camada de inversão térmica, onde a temperatura do ponto de orvalho teoricamente está mais próxima da temperatura ambiente possibilitando a condensação do vapor d'água em forma de nuvens próximas à vertente, que remete ao mecanismo de autoconversão da chuva orográfica.

A relação entre os valores de p2 e a PCD apresenta desvios relativos moderados a maiores no período da primavera-verão e, menores entre maio e setembro. Apresentam boa correlação entre si.

A Figura 45 traça um comparativo entre os postos localizados próximos ao divisor de águas $(680 \mathrm{~m})$ da Estrada de Castelhanos. Na vertente continental está p5 a $600 \mathrm{~m}$ de altitude e na vertente oposta, também a $600 \mathrm{~m}$, localiza-se p7.

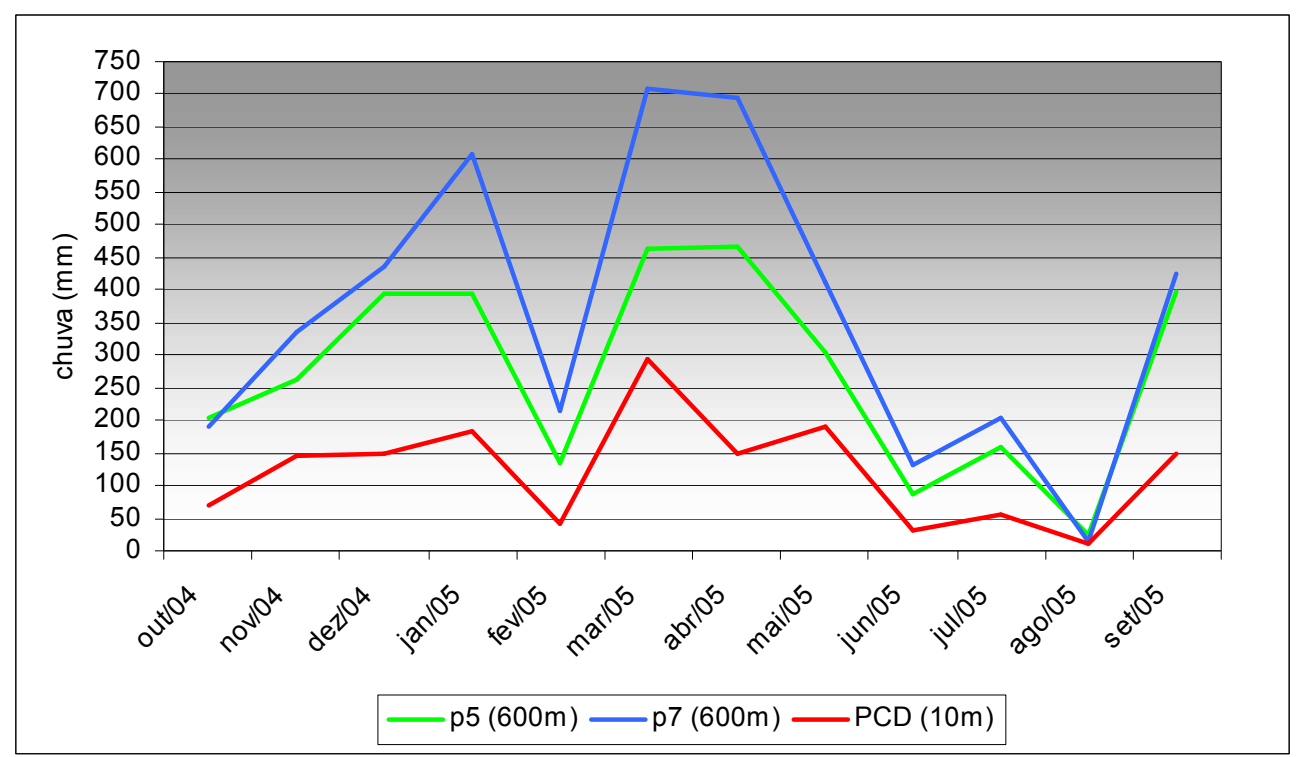

Figura 45 - Comparação entre os postos do divisor de águas quanto à variação espacial da chuva para o ano hidrológico de 2004/2005, em Ilhabela. 
Ambos, p5 e p7, apresentam os maiores desvios de chuva com relação à PCD de Caraguatatuba, com máximos em abril e mínimas em agosto. Apresentam entre si altíssima correlação, diferindo seus totais acumulados na ordem de 15 a $30 \%$, à exceção de agosto.

O posto p5 está em uma delicada situação geográfica, por estar próxima aos trechos mais elevados da estrada, recebe quantidades de chuva bem significantes em relação aos outros postos, é o segundo mais chuvoso, perdendo para p7, porém, por estar a sotavento, também tem controle regulado segundo a característica da chuva orográfica que possivelmente ocorre em p7. Tanto quanto $p 5, p 7$ também localiza-se em especial situação. É o posto mais alto do conjunto, voltado para o oceano e para os ventos predominantes, logo, propício à formação da chuva orográfica.

Curiosamente, p7 apresenta, além das maiores quantidades de chuva coletadas, o menor volume de chuva da série, em agosto. As características, o tipo e a quantidade da chuva de inverno, em agosto, associada a uma passagem de frente fria e aliada às características locais do sítio de instalação (vegetação secundária, alta, heterogênea) geraram diferenças pouco significativas entre p7 e a PCD.

De forma geral, os menores desvios relativos à PCD de Caraguatatuba estão no último mês do outono e início do inverno e claramente localizados em p1 e p2; os desvios relativos mais elevados estão em março e abril, concentrados em p7, p9 e p12, os meses de chuva mais intensa.

Uma análise superficial da distribuição das freqüências mensais (setenta e duas observações) dos valores de chuva conforme a altitude na Estrada de Castelhanos foi realizada. Pode-se afirmar que houve concentração dos valores $(51,4 \%)$ de chuva com montantes até $200 \mathrm{~mm}$ precipitados entre todos os postos 
independentemente da altitude, mas que representam apenas $24 \%$ de toda a chuva da série analisada; são mais comuns na vertente continental. Uma segunda faixa de concentração de valores de chuva está no intervalo que vai de 301 até 400mm, apesar de menor em participação (17\%) representa sozinho $25 \%$ da chuva observada; são mais comuns na vertente oceânica. As freqüências de chuvas acima dos $501 \mathrm{~mm}$ constituem-se apenas $8,5 \%$, porém, produzindo, no entanto, $21 \%$ do total da chuva e, ocorrem apenas na vertente oceânica, preferencialmente em altitude mais elevada. O posto p7 é o que apresenta maior amplitude de chuva durante o ano, com a maior e menor quantidades de chuva da série, já que está sujeito a mais formas de precipitação e influências geográficas locais. $\mathrm{O}$ 1, ao contrário apresenta a menor amplitude pluviométrica. Sua localização, de extremo abrigo, parece ser determinante no controle das quantidades de chuva aí precipitadas.

Como tendência geral apontam os dados para uma diferença significativa nos valores de chuva na medida em que a altitude aumenta dispondo de seus máximos na vertente oceânica a $600 \mathrm{~m}$ no posto p7 e conseqüente redução na vertente oposta.

A questão do aumento da chuva conforme a altitude poderia ser resolvida apenas considerando o total anual dos postos. Abaixo dos 100m de altitude: p1 (1758mm) e p12 (3037mm), entre 100 e $500 m$ temos p2 (2173mm) e p9 (3462mm) e, entre os 600 e $690 \mathrm{~m}$, os postos p5 e p7 apresentaram 3290 e $4372 \mathrm{~mm}$. Mas sendo esta uma relação natural e proporcional, até uma certa altitude, abandonamos a análise simplista.

As Figuras 46 e 47 partem do total de chuva para o $\mathrm{AH} \mathrm{04/05}$ e de suas relações com a altitude, nas vertentes opostas, a fim de se verificar a validade da 
hipótese de que a chuva aumenta até certa altitude para depois decrescer, por meio da análise da correlação linear existente entre ambas, de onde se pode extrair o gradiente pluviométrico local.

A análise da reta de regressão entre a chuva e a altitude na vertente continental da Ilha de São Sebastião descreve elevada correlação apresentando $R^{2}=0,99$ (de uma escala que varia entre 0 e 1). (Figura 46)

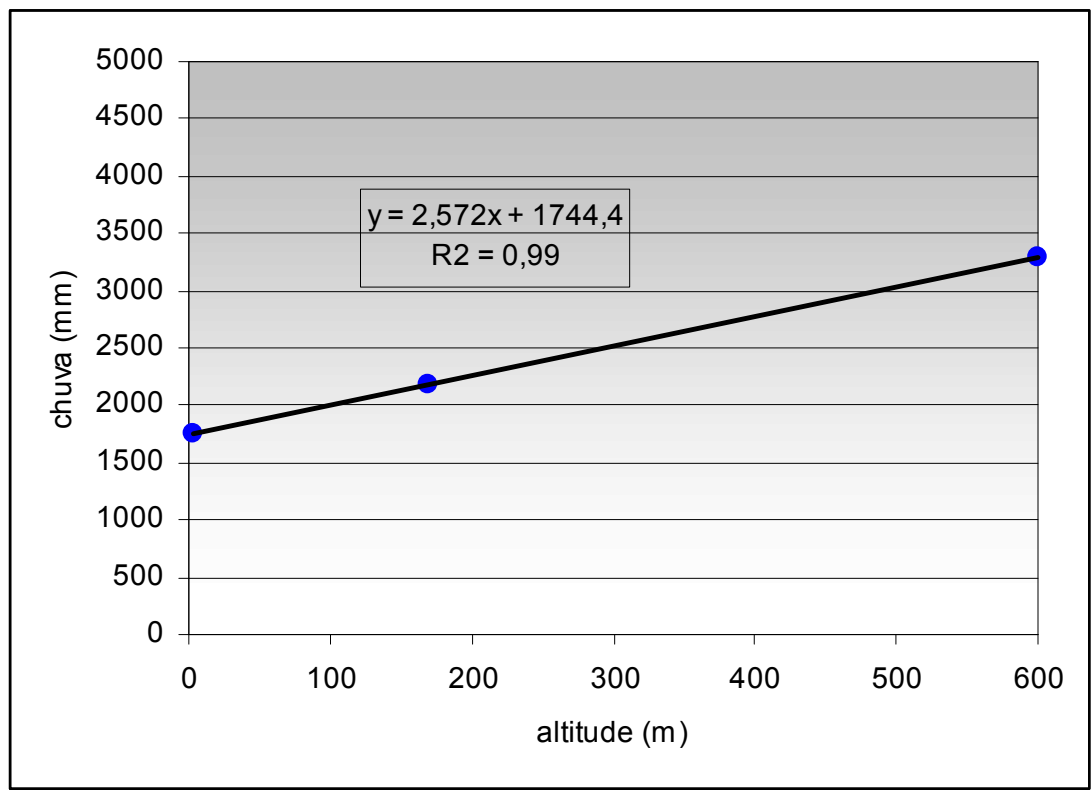

Figura 46 - Correlação entre o aumento da chuva com a altitude para a vertente continental da Estrada de Castelhanos no ano hidrológico de 2004/2005.

A equação descreve que para todo valor de y (chuva) há uma dependência direta gerada por $\mathrm{x}$ (relevo) que corresponde ao aumento da chuva com a altitude. A cada metro de altitude que se eleva, deve-se aplicar o fator do gradiente pluviométrico para a descoberta do valor de chuva correspondente.

Em nosso caso, a partir dos $3 m$ de altitude (p1), que registrou um total de 1744,4mm no AH 04/05, na vertente continental da Ilha de São Sebastião, a chuva aumenta em torno de 2,5 vezes por metro de altitude. 
Para a vertente oceânica da ilha (Figura 47) a análise da reta também apresenta elevada correlação, porém, com $\mathrm{R}^{2}=0,96$, levemente menor que o da vertente oposta.

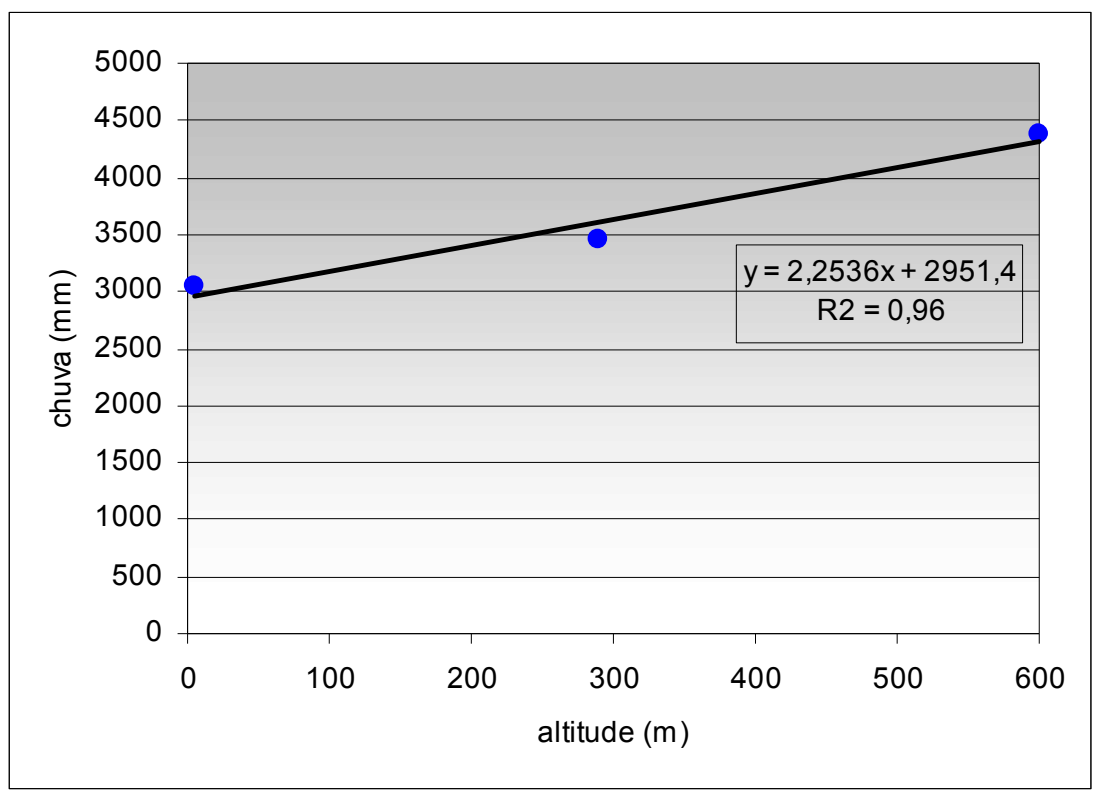

Figura 47 - Correlação entre o aumento da chuva com a altitude para a vertente oceânica da Estrada de Castelhanos no ano hidrológico de 2004/2005.

Para a vertente oceânica da ilha a equação descreve um aumento um pouco menor, em torno de 2,25 vezes por metro de altitude, a partir dos $5 \mathrm{~m}$ de altitude que registrou em p12, 2951,4mm.

A Figura 48 mostra a síntese espaço-temporal dos dados coletados. É uma síntese da correlação entre o tempo (ano hidrológico) e o espaço (sítios dos pluviômetros), por meio dos totais mensais de chuva em sua distribuição. Os três valores à esquerda representam a vertente continental, enquanto aqueles à direita representam a oceânica.

Com esta representação, a chuva ganha caráter hierárquico ou classificatório. Foram definidas 8 classes para as quantidades de chuva, com intervalos de $100 \mathrm{~mm}$ e variando entre $0 \mathrm{~mm}$ a $800 \mathrm{~mm}$. 
1. Abaixo de $100 \mathrm{~mm}$ de chuva, em agosto, é notadamente o mês menos úmido em todos os postos.

2. Entre 101 e $200 \mathrm{~mm}$, predominantemente em outubro, junho e julho, ocorre em p1, p2 e p12.

3. Entre 201 e 300mm, notada nos meses chuvosos para p2, p5, p9 e p12 (setembro a abril).

4. Entre 301 e $400 \mathrm{~mm}$ de chuva, nos meses mais chuvosos na vertente continental.

Notamos o claro deslocamento dos totais de chuva para a vertente oceânica, mais comum às classes superiores.

5. Entre 401 e 500mm, se distribuem entre os postos de altitude acima de 170m (p2, p5, p7 e p9).

6. Nos meses de concentração de chuva (dezembro, março e abril), temos a classe 501 a 600mm, em p7, p9 e p12.

7. Entre 601 e $700 \mathrm{~mm}, \mathrm{p} 7$ e p9, em março.

8. Acima dos $700 \mathrm{~mm}$, também em março, apenas p7; o mais alto e mais chuvoso da Estrada de Castelhanos, na vertente oceânica. 


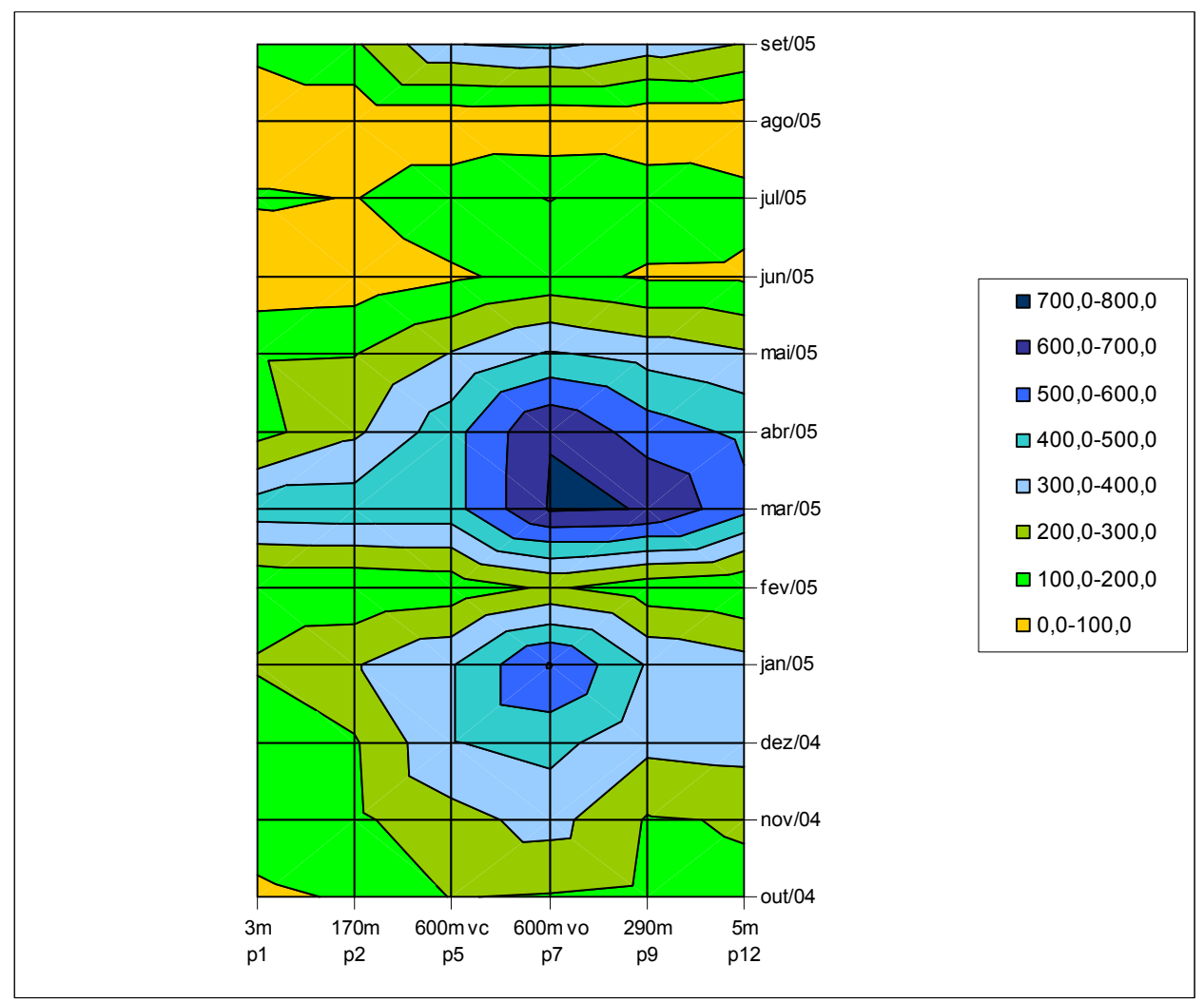

Figura 48 - Síntese espaço-temporal da distribuição da chuva na Estrada de Castelhanos para o ano hidrológico de 2004/2005.

A Figura 49 mostra um esquema da interação entre a brisa do mar, ventos predominantes e processos convectivos na Estrada de Castelhanos, baseado em Leopold (1949). O resultado dessa interação é a formação de uma frente de brisa que regula a nebulosidade e certamente a chuva, a sotavento da ilha, mas que não influi na ocorrência da chuva orográfica. Cada número representa uma situação com uma referência fotográfica presente neste trabalho. Para a situação número 1 , ver Figura 5 (p. 26), para a situação 2, ver Figura 7 (p. 29), para a número 3, ver Figura 19 (p. 46) e, para a situação 4, ver Figura 50 (p. 127). 


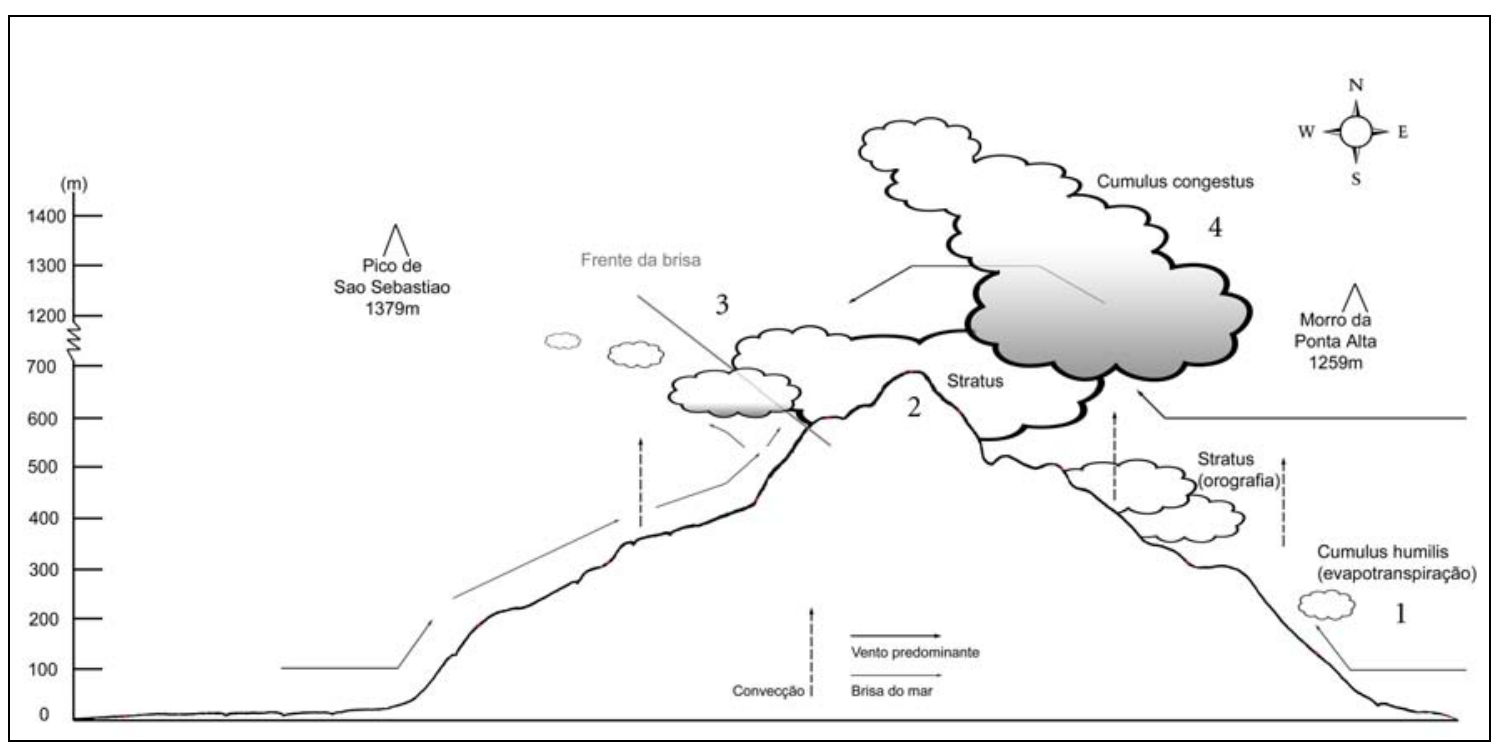

Figura 49 - Esquema teórico da interação da entre a brisa do mar e os ventos predominantes e distribuição espacial aproximada da nebulosidade na Estrada de Castelhanos, baseado em Leopold (1949).

Em um dia teoricamente ideal ensolarado e sem a possibilidade da passagem de algum tipo de frente, a brisa marinha se faz atuante já nas primeiras horas de aquecimento favorecendo a formação de cumulus (humilis) de bom tempo, gerado pelo processo de evapotranspiração, em altitudes menores na vertente ensolarada da montanha, em nosso caso, na vertente voltada para o oceano. A contínua ascenção da brisa do mar intensifica junto aos ventos predominantes a formação de nuvens orográficas (stratus), que surgem "encostadas" na vertente, porém de pouco desenvolvimento. $\mathrm{O}$ aquecimento intenso da vertente exposta à insolação dispara o movimento convectivo, que pode dar origem a nuvens do tipo cumulus (congestus) e, possívelmente cumulonimbus, caso o aquecimento se mantenha constante ou intensificado. Na transposição da cumeeira da ilha, o movimento turbulento do ar que está ligado ao conceito de mistura do vapor d'água ao ar permite a formação da nebulosidade do tipo stratus, ao nível do solo, a partir dos 500 - 600m de altitude, quando ganha o status de nevoeiro. $\mathrm{O}$ topo do cumulus, agora mais desenvolvido tende a "dobrar" e se dispersar no sentido do vento predominante. A sotavento da 
cumeeira, os ventos predominantes de relevo abaixo agora encaram a brisa do mar que está soprando relevo acima. Seu choque dá origem à frente de brisa, que auxilia na dispersão da nebulosidade e que garante menores quantidades de precipitação nesta vertente.

A Figura 50 mostra duas imagens do setor norte da Ilha de São Sebastião, registrando a formação de nebulosidade cumuliforme na Baía de Castelhanos, que muito se assemelha ao processo de intensificação orográfica "convecção disparada".

a)

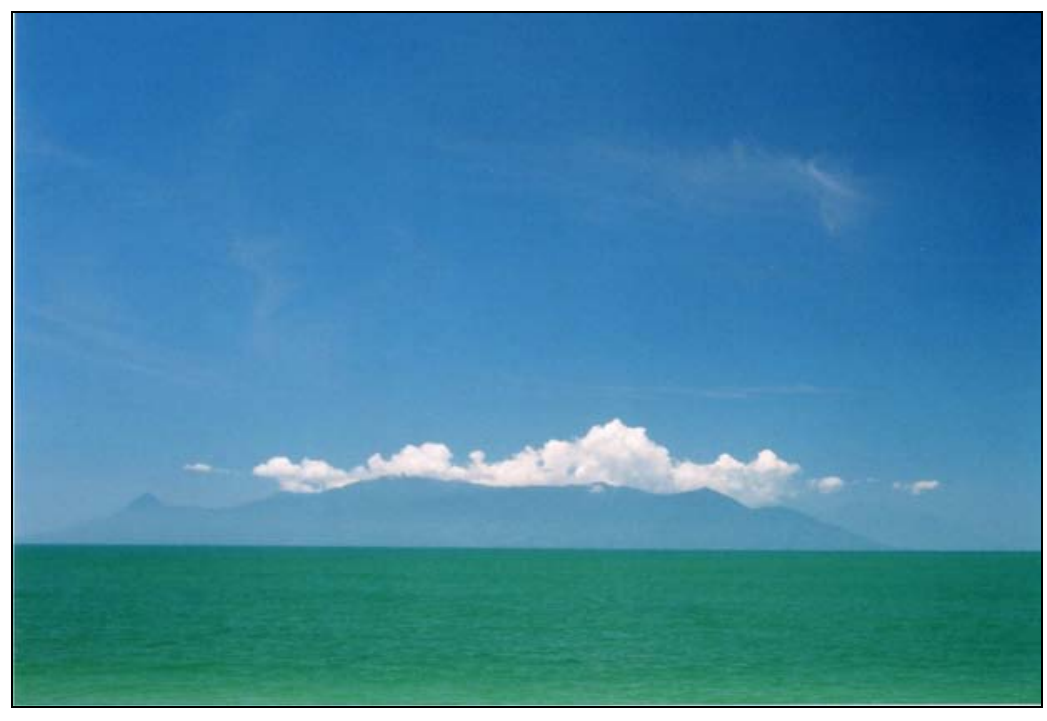

b)

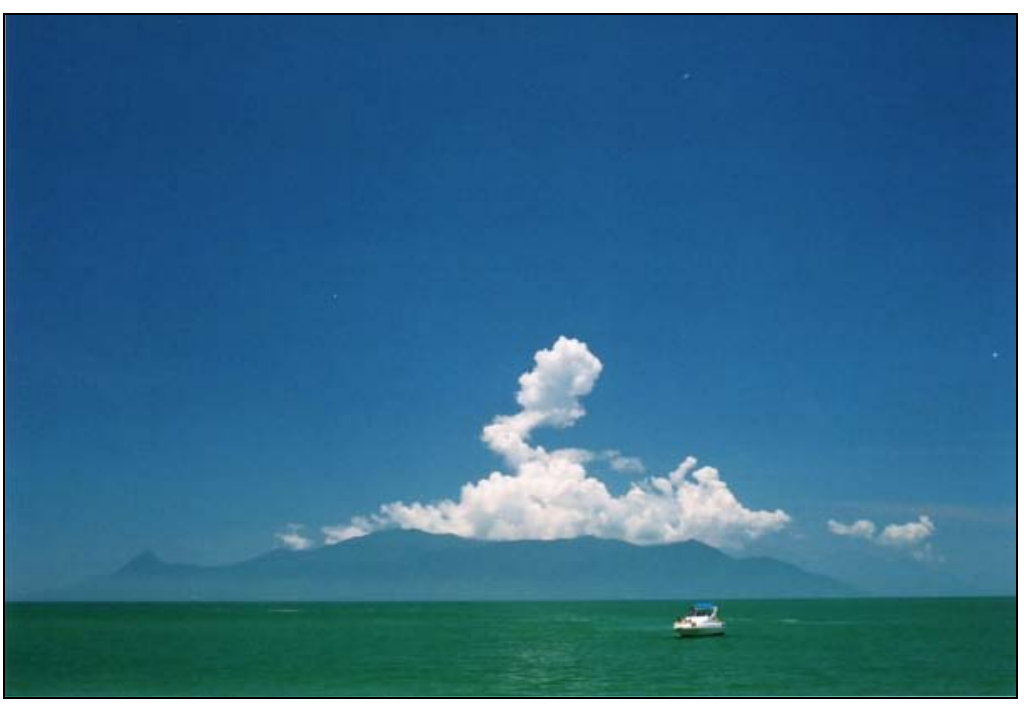

Figura 50 - Imagens do setor norte da llha de São Sebastião, a partir da Ponta Azeda (Ubatuba), registrando a formação de nebulosidade de desenvolvimento vertical (jan/2005, às $13 \mathrm{~h}-\mathrm{a}, \mathrm{e}$ às 13h 15min - b). Em a - cumulus humilis e, em b - cumulus mediocris. 
A diferença de tempo entre as duas imagens é de $15 \mathrm{~min}$, aproximadamente. $\mathrm{O}$ dia ensolarado certamente ativou o processo convectivo na atmosfera circundante à vertente oceânica da ilha. O fluxo de ar fraco na Figura 50a não permite que a nebulosidade se desenvolva em altitude. Na Figura 50b, o fluxo de ar já em franco movimento ascendente, demonstra a intensidade no processo. Infelizmente não temos a confirmação de chuva para este evento.

A Figura 51 é uma síntese do conhecimento adquirido durante o processo de pesquisa e aplicado sobre a área de estudo. Procura, por meio da representação gráfica estática, corroborar com as teorias utilizadas, apesar da natureza altamente dinâmica dos processos atmosféricos envolvidos.

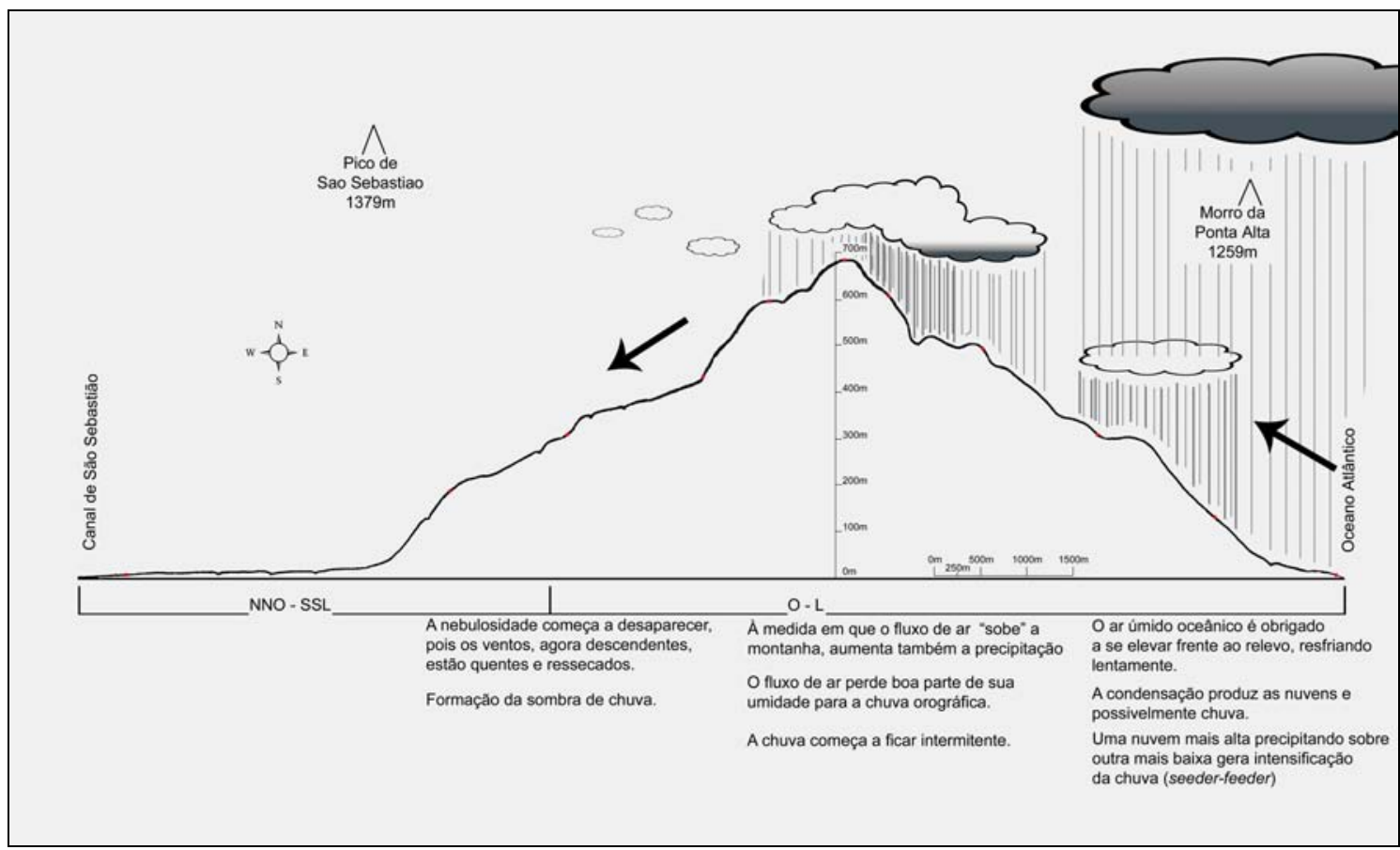

Figura 51 - Esquema teórico da distribuição da chuva na Estrada de Castelhanos.

São descritos os processos intensificadores da chuva orográfica na Estrada de Castelhanos: seeder-feeder e autoconversão. Não incluímos o processo da convecção disparada, pois o estudo de seu mecanismo encontra-se bem 
desenvolvido. Deve-se ler o esquema da direita para a esquerda ou de leste para oeste, em virtude da posição geográfica da ilha. Na primeira situação (seederfeeder) o vento predominante transporta umidade na forma de nebulosidade de médios níveis, que por estar mais alta precipita sobre a nuvem mais baixa que intensifica a precipitação da chuva. Porém, o ar que se eleva sobre a vertente a barlavento não é defletido ao redor da ilha. A configuração morfológica da Baía de Castelhanos e a presença de vales profundos canaliza o fluxo de ar fazendo com que ocorra um levantamento turbulento que favorece a formação de nuvens orográficas por meio do resfriamento adiabático e, possivelmente chuva (autoconversão), nas altitudes superiores aos 600m de altitude. Ao transpor o divisor de águas, o fluxo de ar já precipitou boa parte da umidade que transporta, tornandose "ressecados". Na vertente oposta, com o fluxo de ar em descendência, já sem umidade, gera-se a sombra de chuva. Considerando-se as trocas entre os sistemas atmosféricos e a passagem freqüente de frentes na região, a intensa insolação a que a área está sujeita, a presença do oceano e, a expressão do relevo da ilha, acreditamos que os três mecanismos ocorram na área de estudo, com grande possibilidade de distinção entre si. 


\section{Considerações finais}

Foram discutidas as relações do relevo com a formação e distribuição da chuva orográfica na Ilha de São Sebastião, especificamente, na Estrada de Castelhanos e, resolvidas as questões propostas com pertinência dada a complexidade do tema proposto.

Uma das limitações desse estudo reside na impossibilidade de se compor um mapa da distribuição da chuva mais preciso da ilha devido a dois motivos. O primeiro é que a disposição dos pluviômetros forma uma linha que realça a morfologia do perfil da estrada, logo pode ser entendido como uma síntese W-L do evento orográfico, mas não permite a extrapolação fiel dos resultados para toda a área da ilha. E, segundo, que as localidades mais distantes da aglomeração urbana, não dependem apenas de uma caminha, mas sim de longos trajetos realizados apenas por veículos especiais ou embarcações.

Outra limitação está evidente na baixa densidade de postos climatológicos que impossibilitam uma compreensão mais real da dinâmica climática na Ilha de São Sebastião, permitindo apenas uma análise aproximada da chuva na vertente continental.

Os procedimentos e métodos utilizados para a conclusão foram adequados para as conclusões obtidas neste trabalho. O modelo proposto por Leopold (1949) acerca da interação entre a brisa marinha e os ventos predominantes e aqueles propostos por Bergeron (1968) acerca dos três tipos de chuvas orográficas foram considerados de extrema relevância, para uma área carente de dados 
sistematizados. O método por nós utilizado, baseado em Tarifa (1975), precisa de ajustes para que possa com propriedade servir a todas as estações do anos.

De forma geral as conclusões são frutos da análise dos dados de campo que reforçam a idéia de oposição entre as vertentes.

1. Os pluviômetros experimentais cumpriram com sua função de captar adequadamente os volumes de precipitação na Estrada de Castelhanos, Ilhabela (SP), porém, para sua otimização devem ser redimensionados.

2. As condicionantes geográficas locais do sítio de instalação dos pluviômetros exerceram influência mais pronunciada nos valores de p7 $(600 \mathrm{~m})$, que registra os maiores totais e a maior amplitude de chuva da série analisada, devido a quatro fatores em essência, o nível de interferência da vegetação estimado em $85 \%$, apresentando espécies vegetais altas, de dossel fechado e estrutura da chuva de inverno (curta, fina e de baixa intensidade) para o valor menor (inverno) e, sua posição a barlavento e altitude que induzem ao processo de intensificação da chuva orográfica, para as quantidades de chuvas máximas (verão).

3. Ficou evidenciado o claro efeito da participação do relevo na distribuição espacial da chuva quando observados os totais agrupados por vertente: a vertente continental (em situação de abrigo aos fluxos predominantes de SE) da Ilha de São Sebastião recebe $39,9 \%$ da chuva precipitada na área, enquanto a vertente oceânica (exposta aos fluxos) recebe 60,1\%, o que representa um decréscimo de $20,2 \%$ dos totais, o que caracteriza a sombra de chuva. Individualmente, p1 $(3 \mathrm{~m})$, no sopé do maciço a sotavento, é considerado o posto menos chuvoso. 
4. Também ficou evidenciado o aumento da chuva a barlavento conforme a altitude (valores mais elevados acima dos $600 \mathrm{~m}$ - p7) por meio do cálculo do gradiente pluviométrico, que permite a identificação da chuva orográfica.

5. Os também elevados valores de chuva observados em p5 (600m na vertente continental), porém, inferiores a p7 (mesma altitude, vertente oposta) caracterizam o efeito orográfico mesmo no divisor de águas, o ponto mais alto da estrada.

6. O a influência do relevo se faz por meio da canalização dos ventos predominantes pelos vales, que gera um fluxo de ar turbulento e dinamiza os processos de condensação e precipitação. Em dias ensolarados, a participação os movimentos atmosféricos convectivos enfatiza esses mesmos processos. A formação de nebulosidade altimetricamente mais desenvolvida e a intensificação das chuvas pelos processos de Bergeron são conseqüências esperadas.

7. O ambiente ilhéu contém os requisitos necessários para influenciar na formação da chuva orográfica, o oceano provê a atmosfera de vapor d'água, a competência do vento predominante em transportar umidade é ampliada quando da brisa do mar sopra na mesma direção, há formação de nebulosidade característica na transposição dos fluxos de ar sobre o divisor de águas, há diferenças nos montantes de chuva observados por vertente, há intensificação da chuva com a altitude, logo, além dos mecanismos que formam a constante nebulosidade orográfica presente na ilha, pode-se afirmar que há uma gênese de chuva orográfica na Ilha de São Sebastião

8. Não foi possível desvendar com propriedade a resposta de relação chuva versus relevo na atuação dos principais tipos de tempo. 
Durante o processo de confecção desta dissertação de mestrado surgiram questionamentos os quais não estávamos aptos a responder. Tais questionamentos são aqui expostos. Em verdade, são lacunas do conhecimento climatológico regional que passam desapercebidas do leitor menos atento. São campos de pesquisa prontos para serem avaliados.

Uma análise climatológica aprofundada do canal de São Sebastião é necessária, pois que poderia revelar as feições locais do clima a que Monteiro, em 1973, se refere.

No canal de São Sebastião, parecem ser instigantes estudos mais detalhados acerca dos processos da evaporação correlacionada às temperaturas das correntes marinhas, da dinâmica das brisas do mar e da terra, do efeito canalizador sobre os fluxos de vento e da formação de nuvens.

$\mathrm{Na}$ llha de São Sebastião e outras áreas do Litoral Norte, comparações entre as dinâmicas climáticas locais, são inevitáveis e poderiam fornecer outros subsídios ao entendimento da distribuição e gênese das chuvas.

Também poderia ser interessante uma avaliação da influência do relevo na formação de nuvens orográficas sobre as ilhas menores do município de llhabela. 


\section{Referências bibliográficas}

AB'SABER, A.N. Os domínios de natureza no Brasil: potencialidades paisagísticas. São Paulo: Ateliê Editorial, 2003.

ARMANI, G. Proposta metodológica para trabalho em microclimatologia. In: SEMINÁRIO DE PESQUISA EM GEOGRAFIA FÍSICA, 2, 2004, São Paulo. Anais... São Paulo. 1 CD-ROM.

ARMANI, G. Interações entre a atmosfera e a superfície terrestre: variações da temperatura e umidade na bacia B do núcleo Cunha (IF) - SP. Dissertação (Mestrado em Geografia Física). Faculdade de Filosofia Letras e Ciências Humanas, Universidade de São Paulo, São Paulo, 2004.

AYOADE, J.O. Introdução à Climatologia para os trópicos. 2a . ed. São Paulo: Difel, 1988.

BLANCO, C.M.R. Processos de intensificação orográfica da precipitação na Serra do Mar em São Paulo. Dissertação (Mestrado). Instituto Astronômico e Geofísico, Universidade de São Paulo, São Paulo,1999.

CONTI, G.N.; MENDES, C.A.B. Sensoriamento remoto para estimativa da precipitação no estado do Rio Grande do Sul. In: Simpósio Brasileiro de 
Sensoriamento Remoto, 11, 2003, Belo Horizonte. Anais... Belo Horizonte: INPE, 2003. p. $1153-1160$.

CONTI, J.B. A Intensidade do Efeito Orográfico sobre as Precipitações na Região do Puy-de-Dome (França). Boletim Paulista de Geografia, São Paulo, n 44, p. 15-38, 1967.

CONTI, J.B. Circulação secundária e efeito orográfico na gênese das chuvas na região lesnordeste paulista. Tese (Doutorado). Instituto de Geografia, Universidade de São Paulo, São Paulo, 1975.

CONTI, J.B.; ANGELO FURLAN. S. Geoecologia: o clima, os solos e a biota. In: ROSS, J.L.S. (Org). Geografia do Brasil. 2 ed. São Paulo: EDUSP, 1998. p. 67 a 198.

CONTI, J.B. Geografia e Climatologia. Revista Geousp, São Paulo, n9, 2001.

CRUZ, O. A Serra do Mar e a preservação de suas vertentes. Revista Orientação, n7, São Paulo, 198p.

EMBRAPA. Arroz e Feijão (GO). Francisco J. P. Zimmermann. Estatística Aplicada à Pesquisa Agrícola. 2004, p. 93 - 100. 
GALVANI, E.; SOUZA, I.A. Quantificação em Geografia Física: a questão das unidades de medidas. In: SEMINÁRIO DE PESQUISA EM GEOGRAFIA FÍSICA, 2, São Paulo. Anais... São Paulo, 2004, 1 CD-ROM.

GUERRA, A.J.T., CUNHA, S.B. (Org.) Geomorfologia: Uma Atualização de Bases e Conceitos. $2^{\mathrm{a}}$ ed. Rio de Janeiro: Bertrand Brasil, 1995. 472p.

LEOPOLD, L. B. The interaction of trade wind and e sea breeze. Journal of Meteorology, Hawaii, v. 6, p. 312-320, 1949.

LIBAULT, A. Os quatro níveis da pesquisa geográfica. São Paulo, USP,Instituto de Geografia, 1971. 14p. (Série Métodos em Questão, 1).

MEGALE, J. F. (Org.) Max. Sorre. São Paulo: Ed. Ática, 1984.

MILANESI, M.A. O Litoral Norte do Estado de São Paulo e a llha de São Sebastião: breve estudo sobre a pluviometria em seus arredores. Monografia (Trabalho de Graduação Individual). Faculdade de Filosofia Letras e Ciências Humanas, Universidade de São Paulo, São Paulo, 1997.

MILANESI, M.A. A ilha de São Sebastião no Estado de São Paulo: estudos pluviométricos. In: Simpósio Brasileiro de Climatologia Geográfica, 6, Aracajú. Anais... Aracajú, 2004. 1 CD-ROM. 
MILANESI, M.A.; GALVANI, E. Pluviômetro experimental para localidades remotas. In: Simpósio Brasileiro de Geografia Física Aplicada, 11, São Paulo. Anais... São Paulo, 2005. 1 CD-ROM.

MILANESI, M.A.; GALVANI, E. Preenchimento de falhas em banco de dados climatológicos de curto período de observação. In: Simpósio Brasileiro de Climatologia Geográfica, 7, Rondonópolis. Anais... Rondonópolis, 2006. 1 CD-ROM.

MONTEIRO, C.A.F. A frente polar atlântica e as chuvas de inverno na fachada sul-oriental no Brasil: contribuição metodológica à análise rítmica dos tipos de tempo no Brasil. São Paulo, USP, Instituto de Geografia, 1969. 68p. (Série Teses e Monografias, 1).

MONTEIRO, C.A.F A dinâmica climática e as chuvas do Estado de São Paulo: estudo geográfico em forma de atlas. São Paulo, USP, Instituto de Geografia, 1973. $129 p$.

MONTEIRO, C.A.F A análise rítmica em Climatologia: problemas da atualidade climática em São Paulo e achegas para um programa de trabalho. São Paulo, USP, Instituto de Geografia, Laboratório de Climatologia, 1971. 21p. (Climatologia 1).

NUNES, L.H. Relação entre precipitação anual e altimetria no Estado de São Paulo. In: Simpósio de Geografia Física Aplicada, 5, São Paulo. Anais... São Paulo: FFLCH, 1993. p.407-413. 
NUNES, L.H. Distribuição espaço-temporal da pluviosidade no Estado de São Paulo: variabilidade, tendências, processos intervenientes. Tese (Doutorado) Escola Politécnica, Universidade de São Paulo: São Paulo, 1997.

PEZZOPANE, J. E. M. et al. Caracterização da chuva horária em três locais do Estado de São Paulo: um subsídio ao planejamento de operações agrícolas de campo. Sci. Agric., Piracicaba, 52 (1): 70-77, jan./abr. 1995.

PUVANESWARAN, K.M.; SMITHSON, P.A. Precipitation - Elevation Relationships over Sri Lanka. Theoretical and Applied Climatology, Áustria, Springer-Verlag, 1991.

Roe, G. H.; Montgomery, D. R.; Hallet, B. Orographic precipitation and the relief of mountain ranges, J. Geophys. Res., Seattle, v. 108 (B6), 2315, 2003.

ROE, G. H. Orographic precipitation. Annu. Rev. Earth Planet. Sci. Seattle, v. 33, p. 645-671, 2005.

ROSS, J.S. (Org.). Geografia do Brasil. 2ª ed. São Paulo: EDUSP, 1998.

SANT'ANNA NETO, J.L. Ritmo climático e a gênese das chuvas na zona costeira paulista. São Paulo, SP. Dissertação (Mestrado). Faculdade de Filosofia Letras e Ciências Humanas, Universidade de São Paulo, São Paulo, 1990.

SANT'ANNA NETO, J. L. As chuvas no Estado de São Paulo: contribuição ao estudo da variabilidade e tendência da pluviosidade na perspectiva da análise 
geográfica. Tese (Doutorado) Faculdade de Filosofia Letras e Ciências Humanas, Universidade de São Paulo, São Paulo, 1995.

SMITH, R.B. The influence of mountains on the atmosphere. B. Saltzman, Ed. Advances in Geophysics. New Haven, v. 21, p.87-230. 1979.

SMITH, R. B.; BARSTAD, I. A linear theory of orographic precipitation. American Meteorological Society. New Haven, v. 61, p.1377-1391. 2004.

TARIFA, J.R. Fluxos polares e as chuvas de primavera-verão no Estado de São Paulo: uma análise quantitativa do processo genético. São Paulo, USP, Instituto de Geografia,1975. 93p. (Série Teses e Monografias, 19).

TARIFA, J.R., AZEVEDO, T.R. (Org.). Os climas na cidade de São Paulo. São Paulo. Laboratório de Climatologia. Revista GEOUSP, Coleção Novos Caminhos $n^{\circ}$ 4. Universidade de São Paulo, 2001.199p.

TROPPMAIR, H. Biogeografia e Meio Ambiente. 4a. ed. Rio Claro. 1995.

Venturi, L. A. B. (Org.). Praticando Geografia: Técnicas de Campo e Laboratório. São Paulo: Oficina de Textos. 2005, p. 175 - 182.

VITTE, A.C.,GUERRA, J.T.G. (Org.). Reflexões sobre a Geografia física no Brasil. Rio de Janeiro: Bertrand Brasil, 2004. 280p. 


\section{Referências Eletrônicas}

Instituto do PVC: vantagens do uso do PVC. Disponível em: <http://www.institutodopvc.org>. Acesso em: 10 de agosto de 2004.

DEPARTAMENTO DE ÁGUAS E ENERGIA ELÉTRICA (SP). Recomendações para instalação de pluviômetro. Disponível em:<http://www.daee.sp.gov.br/acervoepesquisa/relatorios/pluvpmsp/capitulo02.htm >. Acesso em: 30 de agosto de 2004.

INSTITUTO NACIONAL DE PESQUISAS ESPACIAIS. Boletim de monitoramento e análise climática Climanálise. V. 19 - N.10 - out/2004 até o VOLUME 20 - N.9 set/2005. Disponível em:http://www.cptec.inpe.br/products/climanalise/. Acesso em: 5 de dezembro de 2006

\section{CENTRO DE PESQUISA METEOROLOGICA E CLIMATICA APLICADA A} AGRICULTURA: Clima dos municípios paulistas. Disponível em:

<http://www.cpa.unicamp.br/outras-informacoes/clima-dos-municipiospaulistas.html>. Acesso em: 1 de dezembro de 2006.

Prefeitura de Ilhabela. Dados do município. Disponível em: <http://www.ilhabela.sp.gov.br/>. Acesso em: 3 de outubro de 2005. 
Instituto Brasileiro de Geografia e Estatística: população. Disponível em:

<http://www.ibge.gov.br/cidadesat/default.php>. Acesso em: 6 de abril de 2007.

\section{Documentação Cartográfica}

Instituto Brasileiro de Geografia e Estatística. Carta topográfica de São Sebastião -

SF 23 - Y - D - VI - 3. Rio de Janeiro, Ed. IBGE, 1991. mapa colorido Escala 1:50.000. 